\title{
Espacios Naturales en Galicia; un análisis diacrónico de las distintas categorías de protección y de la eficiencia de estas para afrontar el reto de la pérdida de Biodiversidad
}

Recibido: 7 maio 2020 / Aceptado: 1 xuño 2020

(C) IBADER- Universidade de Santiago de Compostela 2020
Resumen Los espacios naturales constituyen uno de los pilares de la conservación de la Biodiversidad y del Patrimonio Natural. Galicia posee una elevada riqueza en ecosistemas marinos y terrestres, así como con un gran número de especies de flora y fauna endémica, rara y amenazada, pero sin embargo también registra un elevado número de factores adversos que de forma individual o sinérgica son responsables de un estado de desequilibrio de los sistemas naturales que se muestra con gran dureza en numerosas áreas del territorio gallego incluyendo a las principales áreas protegidas, donde se muestra con dureza en el desfavorable estado de conservación de los hábitats y especies protegidas. En este trabajo partiendo de un análisis diacrónico de los modelos de espacios naturales se realiza un diagnóstico de la biodiversidad gallega a partir de la información obtenida de distintas fuentes y confrontadas con parámetros y criterios asumidos internacionalmente.

Palabras clave Biodiversidad, Espacios Protegidos, Gobernabilidad, Galicia

Natural Spaces in Galicia; a diachronic analysis of the different protection categories and their efficiency to face the challenge of the loss of Biodiversity,

Abstract Natural spaces are one of the pillars of the conservation of Biodiversity and Natural Heritage. Galicia has a high wealth of marine and terrestrial ecosystems, as well as a large number of endemic, rare and threatened flora

Alfonso de Luaces · Karsten Schröder · Maes Jacobs Müller Environmental Consultants Ltd.

Rue de la Science 19, 1000 Bruxelles, Belgique

https://www.eci-consulting.com/

E-mail: luaces.ecl75@gmail.com and fauna, but nevertheless it also registers a high number of adverse factors that individually or synergistically are responsible for a state of imbalance in natural systems that is very harsh in many areas of the Galician territory, including the main protected areas, where it is harsh in the unfavorable state of conservation of protected habitats and species. In this work, starting from a diachronic analysis of the models of natural spaces, a diagnosis of Galician biodiversity is made based on information obtained from different sources and compared with parameters and criteria assumed internationally.

Key words Biodiversity, Protected Spaces, Governance, Galicia

\section{Introducción}

La conservación de la biodiversidad constituye uno de los retos mayores a los que debe enfrentarse la humanidad en el siglo XXI como han quedado recogidos en el Convenio sobre la Diversidad Biológica (CDB, 1992) y los documentos que desarrollan, así como en la Estrategia de la UE sobre la Biodiversidad hasta 2020 (CE, 2011). Objetivos y retos que han sido integrados en los conocidos como Objetivos para el Desarrollo Sostenible aprobados en el 2015 por las Naciones Unidas (ONU, 2015, 2019). En esta nueva orientación estratégica la Unión Europea (UE) se ha destacado como uno de los territorios del planeta donde más se busca reducir o anular esta pérdida, a través de un conjunto de políticas que inciden tanto en el ámbito ambiental, como se extiende a otras facetas de la sociedad y de la economía. Frente a la evaluación de las políticas globales diseñadas y ejecutadas desde la Unión Europea y de los gobiernos estatales, resulta también necesario plantear un análisis sobre la situación a nivel de los distintos territorios que constituyen los estados aspecto que en España puede y debe realizarse en el ámbito de sus Comunidades Autónomas. Los datos publicados hasta la fecha en función del primer (UE), segundo (Estados) y un tercer nivel (regiones /comunidades autónomas CCAA), no resulta muy alentador. Los objetivos para lograr frenar la 
pérdida de biodiversidad no se han cumplido en muchos territorios, y en algunos, como es el caso de Galicia, la pérdida de biodiversidad se ha incrementado.

En agosto de 2019 se publicaba la Ley 5/2019, de 2 de agosto, del patrimonio natural y de la biodiversidad de Galicia aprobada por el Parlamento de Galicia y promulgada por su presidente. La nueva norma autonómica vino a derogar la Ley 9/2001, de 21 de agosto, de Conservación de la Naturaleza, que estuvo vigente durante 18 años. Esta nueva disposición nos permite analizar el grado en que se están aplicando en el territorio gallego las políticas y estrategias internacionales y europeas destinadas a frenar la pérdida de biodiversidad y fomentar un uso sostenible de los recursos naturales, centrándonos en unos de los aspectos básicos en cualquiera de estas actuaciones que son los espacios naturales.

\section{Material y métodos}

La elaboración de este trabajo de investigación parte de los textos jurídicos publicados tanto en el Diario Oficial de la Unión Europea (DOUE), el Boletín Oficial del Estado (BOE) y el Diario Oficial de Galicia (DOG). Incorporando además información obtenida en publicaciones científico-técnica y de divulgación, así como numerosos datos derivados de las hemerotecas locales, especialmente de la prensa digital, y de los portales web de distintas entidades. Esta información se ha contrastado y ampliado con las distintas visitas que hemos podido realizar a Galicia desde el año 2010 y con entrevistas in situ con personalidades, científicos y ambientalistas de Galicia y de España. Se utilizan también datos de las encuestas que nuestro equipo ha realizado en los últimos años a distintos profesionales en el marco de distintos proyectos llevados a cabo para la Comisión Europea.

\section{Discusión}

Galicia enclavada en el NW de la Península Ibérica (Otero Pedrayo, 1945), es un país de fuertes contraes tanto a nivel geográfico, como climático y ambiental. Existe una abundante y buena información descriptiva sobre el territorio, así como diferentes estudios sobre los componentes de la Geodiversidad y Biodiversidad que se condensan en un conjunto de obras de referencia y fácil acceso (VVAA, 1978; Bouhier, 1979; Izco, 1994; VVAA 1995, 1998; Docampo Barrueco \& Rey Muñiz, 1996; González Prieto \& Vilariño Gómez, 1997 Sanz Larruga, 1997; ADEGA, 2000; Casares Long, 2003; Leiro et al. 2003; Martín Palmero et al. 2004; Salvadores Ramos et al. 2004; Leiro, 2005, 2006; Martinez Roperio, 2005; Ramil-Rego et al. 2005; Díaz-Fierros, 2006; Izco et al. 2006; Leiro, 2007; Leiro \& Daporta Padín, 2007a,b; Leiro et al. 2007; Martínez Carneiro, 1997; Daporta Padín \& Leiro, 2008; Leiro \& Daporta Padín, 2008a,b; Murado, 2008; Ramil-Rego et al. 2008; Ramil-Rego \& Crecente Maseda, 2012; Aguirre de Urcola, 2017; Ramil-Rego et al. 2017; Díaz-Fierros, 2019; Ramil-Rego \& Vales, 2019; Sanz Larruga \& Fernández Carballal, 2019), sin embargo resulta difícil acceder a informes oficiales sobre las actividades llevadas a cabo por los organismos responsables en la gestión medioambiental, cuyos responsables son ávidos en publicar libros de elogio de sus acciones. En este sentido resulta muy llamativa la reducida la información científico-técnica que puede consultarse en el portal web de la Consellería de Medio Ambiente y espacial de la Dirección General del Patrimonio Natural, que en la mayoría de los casos se reduce a aspectos turísticos, no existiendo informes plurianuales o anuales de las labores desarrolladas en los distintos espacios naturales o en el conjunto de la definida como Red de Espacios Naturales Protegidos de Galicia. La falta de información en este portal contrasta con la existente en otras Comunidades Autónomas y especialmente en el portal del Ministerio para la Transición Ecológica.

\section{Las primeras áreas protegidas en España y Galicia}

La declaración de los espacios naturales o espacios protegido en Galicia se remonta a en Galicia a las actuaciones llevadas a cabo por el gobierno de Alfonso XIII (1902-1931) que se materializan en la aprobación de la Ley de Parques Nacionales de 1916 y de un conjunto de Reales Decretos y Ordenes que la Desarrollan. La Ley de 1916 Parques Nacionales establece el primer modelo de áreas protegida de España, embebido en el americano forjado en la segunda mitad del siglo XIX, e impregnándolo posteriormente de valores tradicionales hispanos como los derivados de los conceptos de raza, religión y caza. Un modelo que perduró sin apenas cambios hasta la década de 1970 (Hernández Pacheco,1933; López Ramón \& López Ramón, 1980; Ruiz de Larramendi, 1992; VVAA, 2004; Varillas, 2014, Díaz de los Reyes, 2015). El mismo régimen que instauraba los espacios naturales en España fomentaba con otras disposiciones todo tipo de acciones lesivas contra el medio ambiente, como las relativas a la desecación de humedales (Ley 24/07/2018).

La Ley de 1916 consta de un mínimos preámbulo y tres artículos, en los que se define y caracterizan a los Parques Nacionales: Se crean en España los Parques Nacionales (art. 1). Son Parques Nacionales, para los efectos de esta Ley, aquellos sitios ó parajes excepcionalmente pintorescos, forestales ó agrestes del territorio nacional, que el Estado consagra, declarándoles tales, con el exclusivo objeto de favorecer su acceso por vías de comunicación adecuadas, y de respetar y hacer que se respete la belleza natural de sus paisajes, la riqueza de su fauna y de su flora y las particularidades geológicas é hidrológicas que encierren, evitando de este modo con la mayor eficacia todo acto de destrucción, deterioro ó desfiguración por la mano del hombre (art. 2). El Ministro de Fomento creará los Parques Nacionales, de acuerdo con los dueños de los sitios, reglamentaria los que vaya creando, y consignará en sus Presupuestos las cantidades necesarias para vías de comunicación y sostenimiento de todos ellos (art. 3).

El Real Decreto 23/02/1917, establece dos nuevas figuras de áreas protegidas imbricadas con el modelo de áreas protegidas americano a las que se le otorga rasgos ibéricos: [1] Sitio Natural de Interese Nacional [2] Monumento Natural 
de Interés Nacional. Posteriormente mediante la Real Orden $15 / 07 / 1927$ se modifica a designación de la primera que pasa a para denominarse Sitio Natural de Interese Nacional. En Artículo 2 de la Real Orden se otorga a estos espacios un singular estatus jurídico: "La declaración oficial de Sitio o de Monumento Natural de Interés nacional es de carácter meramente honorífico para los Municipios en cuyo término existan estas bellezas naturales, así como para las Corporaciones oficiales, entidades públicas o privadas y particulares a quien pertenezcan, con el exclusivo objeto y sin otro alcance que el de respetar y hacer que se respeten tales bellezas evitando su destrucción, deterioro o desfiguración por la mano del hombre, y de favorecer en lo posible su acceso por vías de comunicación; y perderán dicho carácter cuando, por causa intencionada o por desidia, desaparecieran o se aminoraran notablemente los fundamentos de tal distinción". A partir de este acto, algunos han malinterpretado los espacios naturales como un "galardón", expresión que en la actualidad todavía se usa en el ámbito político y periodístico para referirse equívocamente a algunas categorías de áreas protegidas. El Gobierno de Alfonso XIII encomendó a los distritos forestales la relación de lugares a ser protegidos, la respuesta de los distritos gallegos fue mínima, no incluyendo inicialmente ningún espacio en las provincias de Lugo y Ourense y un conjunto de pequeñas áreas, desde jardines particulares, miradores, monasterios y elementos naturales dispersos por la geografía de las provincias de Pontevedra y A Coruña.

La acción inicia por el gobierno de Alfonso XIII fue continuada tímidamente por el gobierno de la II República (1931-1939). En esta etapa se declaran los primeros espacios naturales gallegos, los 3 primeros ceñidos al área litoral Atlántico, que se recogen en la Orden del Ministerio de Agricultura de 31/10/1933 (Gaceta 309, 5/11/1933) en la que se declaran Sitios Nacionales de Interés Nacional, tres parajes de Galicia: "La cumbre de la Curotiña de la Sierra del Barbanza"; "El promontorio del Cabo Vilano, y el islote situado en su extremo inmediato" y "La parte culminante del promontorio del Cabo de Vares". Posteriormente mediante una nueva Orden del Ministerio de Agricultura (Orden $13 / 07 / 1935)$, se procedía a la declaración, en esta misma categoría de espacio natural, de un nuevo espacio, el "Monte Alhoya" (Monte Aloia, Tui, Pontevedra). Según la disposición del gobierno de la República se trata de un espacio que debido a sus reducidas dimensiones "no reúne las condiciones que se exigen en los Parques Nacionales, las presenta y muy acusadas para ser declarado Sitio Natural de Interés Nacional". A estos tres espacios se unirá posteriormente un nuevo espacio, el Monte Aloia, un monte vecinal gestionado por la administración forestal con el objetivo de ensayar aquellas actuaciones más productivas para los montes del Distrito Forestal y la incipiente industria papelera. Ello llevo a reconfigurar el monte como un arboreto en el que se plantaron todo tipo de especies exóticas, mientras se alteró y se redujo la vegetación natural al considerarla de nulo valor. La acción del gobierno de la República dejaba de nuevo sin protección legal las áreas naturales más representativas del medio natural de Galicia.
La dictadura franquista autarquía - desarrollismo irracional y desprecio al medio ambiente

El título del apartado refleja a nuestro entender la situación vivida por España durante 4 largas décadas (1936/19391975), pasando de una economía autarquía en la postguerra a un desarrollismo especulativo e irracional que generó graves problemas ambientales, algunos de los cuales tendrán (embalses, urbanizaciones, desecación de humedales, eliminación de bosques nativos, expansión de elementos exóticos, depredación de las supuestas alimañas, colonización y concentración agraria, contaminación química y bacteriológica, etc), son todavía patentes en la mayoría de los territorios y especialmente en Galicia (Díaz-Fierros, 1996; Bermejo Barrera, 2002; Casares Long, 2003; Varela Díaz, 2010; Vázquez, 2010). Paralelamente a este exacerbado ahínco destructor, las autoridades franquistas y sus influencias mediáticas, sociales y económicas, mostraron una tenaz cruzada contra la naturaleza, retornando a los conceptos fisiocráticos y utilitarista al considerar que los recursos son finitos y están libres de ser explotados sin ningún tipo de control o criterio. Los esfuerzos para proteger la naturaleza fueron en consecuencia mínimos, y en la mayoría de los casos diseñados por su efecto propagandístico o para frenar las escasas críticas internas y las más evidentes externas que se cernían sobre una desastrosa gestión ambiental que se fomentaba y promovía desde la administración. Ejemplo elocuente de este proceder fue la declaración de algunos espacios; Doñana (Ley 91/1978), dejando fuera de los mismos, áreas cruciales para su conservación, no regulando los usos adversos a su estado de conservación, cuando no, fomentando otros nuevos igualmente negativos. La declaración de estos y otros espacios naturales realizada por el régimen franquista se hilvano a partir del modelo de área protegidas diseñado por el gobierno de Alfonso XIII y retocado en la II República, que con leves modificaciones fue asumido por el despótico régimen.

La pesada losa del franquismo tuvo consecuencias muy negativas para la preservación del Patrimonio Natural y Cultural de Galicia. En los casi 40 años de dictadura, la superficie de áreas protegidas en Galicia se mantuvo sin cambios, manteniéndose como espacios naturales aquellos declarados por la II República que fueron poco a poco olvidados. Este clima de desinterés por la naturaleza y la necesidad de promover la protección de aquellas áreas más valiosos llevo a un grupo de profesores e investigadores de los laboratorios de zoología y edafología de la Universidad de Santiago a publicar en la revista Braña, una propuesta para la designación de área protegidas en Galicia (VVAA, 1978), que mejoraba sustancialmente el viejo catálogo de sitios realizado por la administración forestal alfonsina. Evidentemente, las autoridades franquistas no asumieron dicha propuesta (Figura 1).

La construcción de los grandes embalses gallegos, especialmente en las cuencas del Miño-Sil, diezmo el mayor corredor fluvial del área Atlántica de la Península Ibérica, marcando el declive, cuando no la desaparición de numerosas especies acuáticas de flora (Nymphoides peltata, Luronium natans) y especialmente de fauna 
(Anguila anguila, Margaritifera margaritifera, Salmo salar). Las actuaciones de colectivización inspiradas en el fascismo italiano llevaron al Instituto Nacional de Colonización (Bosque Maurel, 1984; Monclús \& Pyón, 1988; Mangas Navas \& Barciela López, 1990; Villanueva Paredes \& Leal Maldonado, 1990; Giménez \& Sánchez, 1994; Calzada Pérez \& Alvaro Tordesillas, 2008) a afrontar la desecación de los grandes humedales del interior de Galicia, actuaciones que fueron posteriormente generalizadas por el IRYDA (Martínez Carneiro, 1997; Ramil-Rego \& Domínguez Conde, 2006). La actividad destructiva del INC fue continuada y ampliada por el IRYDA fomentando una política de concentración parcelaria (Miranda et al. 1999; Crecente \& Alvarez, 2002; GómezOrea \& Gómez Villarino, 2013) que extirpo del paisaje gallego túmulos megalíticos, castros, poblados romanos y medievales, así como puentes, molinos, hórreos, muros y chantados, al igual que prosiguió desecando humedales y eliminando superficies de bosques y matorrales, en muchos casos para obtener escuetos beneficios económicos. Una política desarrollista planteada al margen de cualquier criterio ambiental, que favoreció la contaminación de los ecosistemas de aguas continentales y las Rías, así como dejo grave problemas de contaminación en suelos por el descontrol en el manejo del Lindano (Calvelo Pereira et al. 2008). A la vez que fomento una política alimañera más propia de la Edad Media que del siglo XXI (Sobrado Correa, 2003; Corbelle Rico \& Rico Boquete, 2008).

La operación de disimuló ambiental promovida por las autoridades franquista tendrá además dos elementos novedosos que se materializan al final del franquismo. A inicios del mes de noviembre de 1971 el Boletín Oficial del Estado publicaba el Decreto-ley 17/1971, de 28 de octubre, por el que se modifica la Administración Institucional del Ministerio de Agricultura y se encomienda al Gobierno la reestructuración de dicho Departamento. La norma reorganiza los centros de investigación agraria y forestal creados en la primera etapa del franquismo (Instituto Nacional de Investigaciones Agronómicas, Instituto Forestal de Investigaciones y Experiencias, Patronato de Biología Animal), fusionándolos en uno nuevo, el Instituto Nacional de Investigaciones Agrarias (INIA). Y de forma sorprendente eliminaba la poderosa y reaccionaria Dirección General de Montes, para sustituirla por el Instituto para la Conservación de la Naturaleza, más conocido por su acrónimo (ICONA). El lavado de imagen tuvo una corta vida, ya que pronto el ICONA perdió partes de sus competencias y la Dirección General de Montes volvió a resurgir como ave fénix,

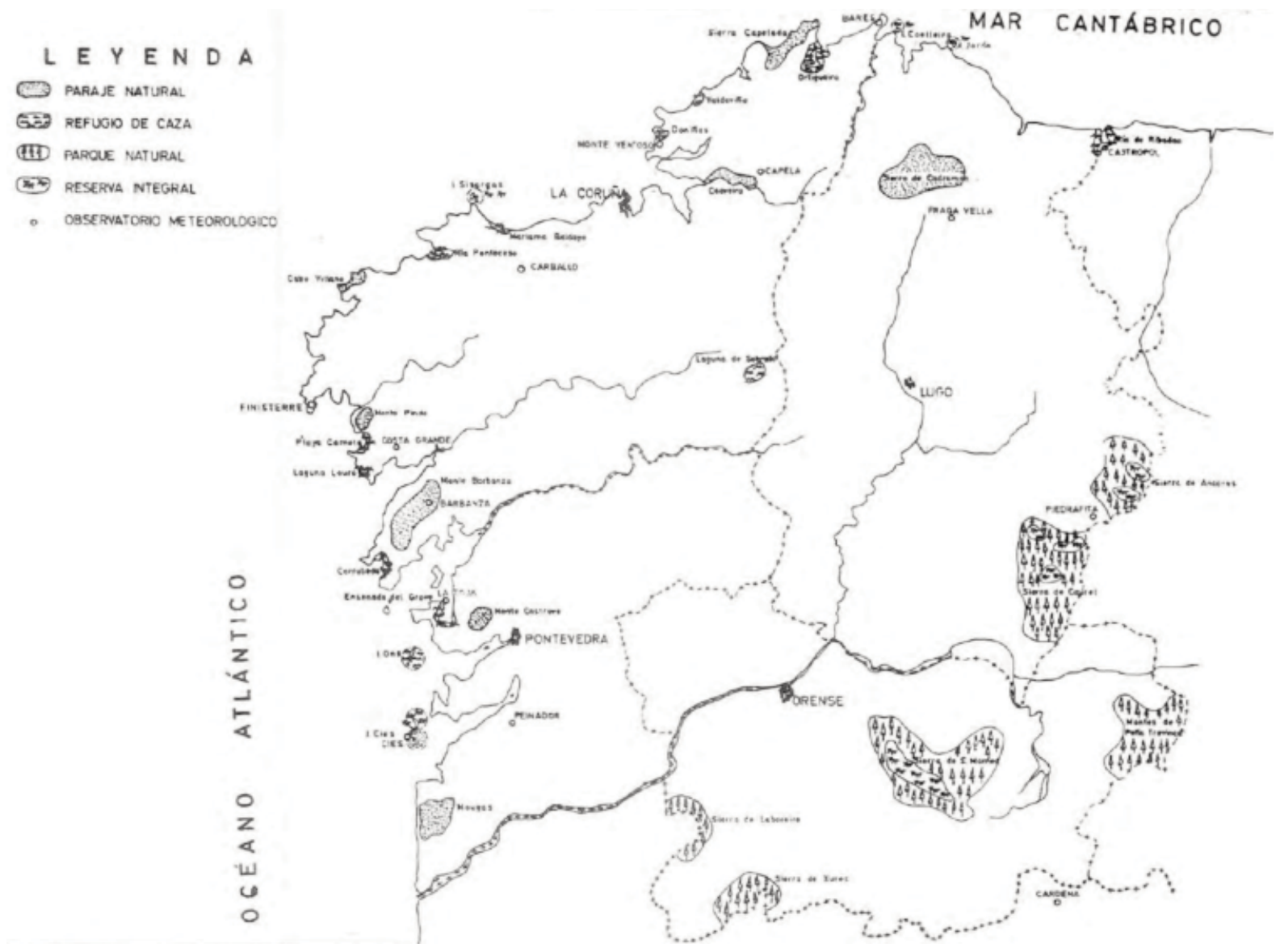

Figura 1.- Posibles zonas a proteger de Galicia (VVAA, 1978), realizada por investigadores de la Universidad de Santiago y publicada por la Sociedad Gallega de Historia Natural 
persistiendo los envites de la reforma democrática, mientras que el ICONA fue eliminado por el Real Decreto 1055/1995, al constituirse el Organismo Autónomo de Parques Nacionales (OAPN). La gestión del ICONA está llena de sombras y pocas luces, al ser incapaz. Las sombras se concentran en la imposibilidad o desinterés de frenar la política degradativa que seguía alterando y destruyendo el medio ambiente en el territorio español, que en el caso forestal en el territorio gallego, conllevara el abandono de la políticas de repoblación forestal con pinos, para lanzarse al fomento del cultivo del eucalipto destinado a abastecer las plantas de celulosas. Las luces inciden en algunas acciones de conservación destinadas a especies singulares de la fauna ibérica, así como de trabajos de seguimientos y el desarrollo de una política de formación y difusión ambiental que tendrá un papel fundamental en el cambio de paradigma sobre la percepción de la naturaleza de la sociedad española.

Siete meses antes de morir el viejo dictador ferrolano, se promulga la Ley $15 / 1975$, de 2 de mayo, de espacios naturales protegidos. La Ley incluye un preámbulo, 7 capítulos con 16 artículos, junto con una disposición final, una disposición transitoria, una disposición adicional y una cláusula derogatoria. En el corto preámbulo de la ley el legislador franquista justifica la nueva norma y plantea de forma encubierta la definición de un nuevo concepto jurídico, el "Espacio Natural Protegido", indicando: "Dentro de la política general de conservación de la Naturaleza, debe ocupar lugar preferente la protección selectiva de aquellos espacios naturales que por sus características generales o específicas sean merecedoras de una clasificación especial. Esta calificación deberá concretarse en una declaración formal que especifique para cada lugar los valores o peculiaridades que la han determinado y los objetivos de todo orden que se pretendan alcanzar. Para ello, resulta necesario contar con los dispositivos legales que permitan, de una parte, la conservación de los valores determinantes $y$, por otra, el desarrollo de una política dinámica de puesta en valor de los mismos a fin de que puedan obtenerse los máximos beneficios que tan privilegiados lugares sean capaces de proporcionar a la comunidad. Dada la extensa gama de posibilidades que ofrece el territorio nacional, en cuanto a la existencia de lugares de estas características, y considerando las relaciones de todo orden que vinculan muchos de ellos con las regiones o localidades donde están ubicados, parece aconsejable aprovechar todas estas circunstancias estableciendo un cauce que facilite la colaboración, dentro de un programa nacional, de todas aquellas Entidades y personas interesadas en estas materias".

La legislación franquista instituye una serie de aspectos básicos en la configuración de los Espacios Naturales Protegido que se mantendrán en normas posteriores. En primer lugar, se generaliza el criterio de utilidad pública ya contemplado para los parques nacionales en la norma alfonsina, considerando ahora en su artículo 14 referido a las Expropiaciones y compensaciones: "1. La declaración de los espacios naturales protegidos llevará aneja la de utilidad pública a efectos de expropiación de los bienes y derechos afectados. Esta facultad sólo podrá ejercitarse en el caso de que los propietarios u otros titulares de aquellos bienes y derechos no convengan con la Administración otra forma de indemnización o compensación de los daños y perjuicios derivados de la reglamentación especial que sea de aplicación. 2.- Cuando se trate de expropiaciones que afecten a Parques Naturales cuya declaración haya sido promovida a instancia de Corporaciones locales, la expropiación se llevará a cabo directamente por éstas en caso de no llegarse al acuerdo a que se refiere el párrafo anterior. 3.- La indemnización o compensación podrá convenirse en metálico, en especie o en una participación en los productos explotables, de una vez o en los períodos que de común acuerdo se determinen" (art. 14). Plantea también la posibilidad de que sobre un mismo territorio concurran diferentes protecciones jurídicas de carácter ambiental: "La declaración de un espacio natural protegido no excluye la posibilidad de que en determinadas áreas del mismo se constituyan otros núcleos de protección, siempre que los mismos adopten alguna de las modalidades definidas en los artículos precedentes" (art. 6). Y plantea además que junto a la declaraciones de ENP promovidas por el Estado, estas también puedan ser llevadas a cabo, en el caso de los Parques Naturales, por entidades privadas: "Tratándose de Parques Naturales promovidos por personas físicas o jurídicas privadas será preciso, para acceder a su creación, que las fincas están inscritas en el Registro de la Propiedad y que conste en el expediente, mediante documento que tenga acceso a dicho Registro, la adscripción de los terrenos a los fines propuestos, mientras no se deje sin efecto por el Estado mediando causa justificada a petición de parte interesada la declaración de Parque Natural" (art. 12). Otro aspectos igualmente llamativo supone la necesidad de asignar una junta consultiva para cada ENP: "Para colaborar con el Instituto Nacional para la Conservación de la Naturaleza en las funciones que le atribuye esta Ley se constituirá un Patronato o Junta para cada espacio natural protegido. Su composición, cometido y funcionamiento se especificarán en el Reglamento correspondiente y habrán de formar parte de los mismos representantes de las Corporaciones locales $y$ de todos los titulares de los diferentes derechos afectados, elegidos éstos entre ellos en el seno de la Organización Sindical" (artículo 10).

En cuanto a las figuras de Espacios Naturales Protegidos, la normativa contemplaba 4 posibilidades: Reservas integrales de interés científico: 1.- Son reservas integrales los espacios naturales de escasa superficie que por su excepcional valor científico sean declarados como tales por Ley con el fin de proteger, conservar y mejorar la plena integridad de su gea, su flora y su fauna, evitándose en ellas cualquier acción que pueda entrañar destrucción, deterioro, transformación, perturbación o desfiguración de lugares o comunidades biológicas. 2.- Estas reservas podrán denominarse Reservas botánicas, zoológicas o geológicas, de acuerdo con el criterio dominante que motiva su declaración. 3.- Su utilización se supeditará al estricto cumplimiento de los fines científicos y de investigación que motiven su declaración. (artículo 2). Parques Nacionales: 1.- Son Parques Nacionales los espacios naturales de relativa extensión que se declaren por Ley como tales por la existencia en los mismos de ecosistemas primigenios que 
no hayan sido sustancialmente alterados por la penetración, explotación y ocupación humana y donde las especies vegetales y animales, así como los lugares y las formaciones geomorfológicas, tengan un destacado interés cultural, educativo o recreativo o en los que existan paisajes naturales de gran belleza. 2.- El Estado fijará las medidas para salvaguardar las características y valores que motivaron su declaración, facilitar el acceso para su uso, disfrute, contemplación y aprovechamiento ordenado de sus producciones e impedir los actos que directa o indirectamente puedan producir su destrucción, deterioro o desfiguración (artículo 3). Parajes Naturales de Interés Nacional. 1.- Son Parajes Naturales de Interés Nacional aquellos espacios, simples lugares o elementos naturales particularizados, todos ellos de ámbito reducido, que se declaren como tales por Ley en atención a las excepcionales exigencias cualificadoras de sus concretos $y$ singulares valores, y con la finalidad de atender a la conservación de su flora, fauna, constitución geomorfológica, especial belleza u otros componentes de muy destacado rango natural. 2.- El disfrute y visita de estos lugares y el aprovechamiento de sus producciones se llevará a cabo de forma compatible con la conservación de los valores que motivaron su creación (artículo 4). Los Parques Naturales. 1.- Son Parques Naturales aquellas áreas a las que el Estado, en razón de sus cualificados valores naturales, por sí o a iniciativa de Corporaciones, Entidades, Sociedades o particulares, declare por Decreto como tales, con el fin de facilitar los contactos del hombre con la naturaleza. 2.- El disfrute público de estos espacios estará sujeto a las limitaciones precisas para garantizar la conservación de sus valores y el aprovechamiento ordenado de sus producciones y acceso a tales efectos de la ganadería (artículo 5).

Finalmente la disposición transitoria marca un rumbo a seguir en relación con los espacios protegido declarados previamente en conformidad con las normas promulgadas por el gobierno de Alfonso XIII y de la II República: "En tanto no se hagan públicas las Leyes o Decretos que en cada caso procedan, el régimen de los Parques Nacionales, Sitios Naturales de Interés Nacional, Monumentos Naturales de Interés Nacional y Parajes Pintorescos existentes, será el establecido en las disposiciones de su creación y en las complementarias que les sean aplicables" (Disposición transitoria).

Las nuevas políticas ambientales y la convergencia con la Unión Europea

La restauración democrática iniciada tras la muerte del dictador y la aprobación de la Constitución de 1978 (CE, 1978), marca un lento cambio de rumbo en la política ambiental del Estado Español que se reforzarán con la adhesión a la Comunidad Económica Europea (Ley Orgánica 10/1985), aunque los efectos adversos de las políticas ambientales forjadas durante el franquismo perduran durante largo tiempo, cuando no agudizan en muchos territorios, incluido el gallego, con incrementos en la contaminación de ríos, rías y suelos, mientras que los medidas de depuración están ausentes o no son efectivas, las concentraciones parcelarias con la destrucción de paisajes rurales y una gran cantidad de elementos del Patrimonio Natural y Cultural, las repoblaciones intensivas de pinos y sobre todo de Eucalyptus que determinaran la rápida y esperpéntica "eucaliptización" del paisaje gallego, especialmente en las provincias de A Coruña y Pontevedra y en el Norte de Lugo (Guitian Rivera, 2002; Cordero Rivera et al. 2017; Eirexas Santamaría, 2017). A los que habría que sumar otros nuevos elementos adversos que irrumpen en la geografía gallega como la construcción de minicentrales, las autopistas, la urbanización de litoral, la eolización de las montañas, etc., actuaciones que se llevaron a cabo sin una rigurosa evaluación ambiental de sus repercusiones. Al igual que en otros territorios españoles, el Gobierno Central, como responsable del Dominio Público Marítimo-Terrestre no actuó de forma eficiente para asegurar su salvaguarda. El límite del DPMT en Galicia resulta completamente ridículo, cuando no totalmente contraria a la propia Ley de Costas (Ley 22/1988), como se constata en la playa de Covas (Viveiro), donde se han situado algunos de los mojones en el área eulitoral, quedando de este modo sumergidos en las pleamares. Situación igualmente esperpéntica se observa en muchas áreas de acantilados de la costa de Lugo, A Coruña y Pontevedra, al situar los mojones en la mitad del talud, o incluso en las zonas bajas de este. O bien al delimitar el DPMT en las crestas de la dunas más próximas a la playa, dejando fuera de la protección de costas grandes superficies de ecosistemas dunares. El confuso límite del DPMT aceleró la urbanización irracional del litoral gallego y su degradación ambiental, situación que se muestra con total dureza en las Rías Baixas, y especialmente en tramos como los de Vilanova de Arousa o Sanxenxo. El análisis de fotografías aéreas desde la década de 1940 a 1990, así como de los distintos proyectos técnicos que se conservan en los archivos del Ministerio de Fomento y de Agricultura, ponen de relieve estas graves alteraciones, siendo escasas, debido al sistema político represivo, la publicación de artículos críticos que se publican durante la dictadura

En una primera etapa las actuaciones sobre el medio ambiente siguen dirigidas desde el gobierno central, a través del Instituto de Conservación de la Naturaleza (ICONA) cuyas actuaciones evidencian una progresivo desacoplamiento con las políticas ambientales que se están promoviendo a nivel internacional y concretamente europeo. Un elocuente ejemplo es la declaración del primer Parque Natural gallego el Monte Aloia (Tui, Pontevedra), un espacio forestal fuertemente transformado y plagado de especies exóticas obra del ingeniero Areses (DXMNAN, 2000), que había sido declarado previamente por la República como Sitio Natural de Interés Nacional (Orden Ministerial 5/07/1935). La declaración del Parque ejecutada por el Gobierno Central se realiza a través del Real Decreto 3160/1978, donde se justifica su declaración por el hecho de que "Se trata de un espacios natural que a sus excepcionales méritos estéticos une un destacado valor forestal, en una zona propicia al turismo". Con ello no se da cumplimiento a los criterios que de acuerdo con la normativa vigente (art. 5 de la Ley 15/1975, de 2 de mayo, de espacios naturales protegidos), al no mencionar ninguno de los de sus "cualificados valores naturales", salvo que se 
asimile equívocamente el arboreto promovido por el Distrito Forestal de la mano del ingeniero Rafael Areses, un destacado forestalita franquista que tuvo un papel importante en la puesta en marcha en la cruzada antinatural diseñada por el ominoso régimen. En este sentido conviene aclarar que las acciones llevadas a cabo en este espacio se centraron con la repoblación de un importante número de especies exóticas, adquiridas en viveros extranjeros, para lo cual hubo que eliminar y marginar a la vegetación natural.

Más sentido tuvo la declaración del segundo Parque Natural Gallego, las Islas Cíes (Real Decreto 2497/1980), tras una serie de actuaciones forestales desafortunadas que devastando gran parte del territorio terrestre para llevar a cabo actuaciones semejantes a las del Monte Aloia, llenando las islas de diferentes especies de pinos, acacias y eucaliptos. La declaración fue incapaz de controla un uso público que de forma progresiva escogía las Cíes como un destino de sol y playa.

Las negociaciones para la entrada del Reino de España en la Comunidad Económica Europea (Ley Orgánica 10/1985) y la configuración del estado de las autonomías ponen en evidencia la deficiente legislación ambiental de España y especialmente la referida a los espacios naturales que sigue rigiéndose por la normativa franquista. El intento por parte del Gobierno de resolver esta situación fue la promulgación de la Ley 4/89, de 27 de marzo, de Conservación de los Espacios Naturales y de la Flora y Fauna Silvestres, estructura en 4 Títulos y 13 capítulos, que engloban 41 artículos, a los que se suman 7 disposiciones adicionales, 2 disposiciones transitorias, 1 disposición derogatorias. 3 disposiciones finales y 1 Anexo, donde se incorporan objetivos y líneas de actuación asumidas por la mayoría de los países a través de distintos acuerdos y reuniones internacionales (Convenio de Berna, Convenio de Bonn, Convenio Cites, Convenio Ramsar, etc).

La Ley a diferencias de las normativas españolas anteriores asume el concepto de que los recursos naturales son finitos y la necesidad de plantear nuevos modelos de desarrollo y crecimiento: "En las sociedades altamente industrializadas de nuestro tiempo se ha extendido, desde hace ya algunos años, la preocupación de los ciudadanos y de los poderes públicos por los problemas relativos a la conservación de la naturaleza. El agotamiento de los recursos naturales a causa de su explotación económica incontrolada, la desaparición en ocasiones irreversible de gran cantidad de especies de la flora y la fauna y la degradación de aquellos espacios naturales poco alterados hasta el momento por la acción del hombre han motivado que lo que en su día fue motivo de inquietud solamente para la comunidad científica y minorías socialmente avanzadas se convierta hoy en uno de los retos más acuciantes. Superados históricamente los criterios que preconizaron un proceso de industrialización, la necesidad de asegurar una digna calidad de vida para todos los ciudadanos obliga a admitir que la política de conservación de la naturaleza es uno de los grandes cometidos públicos de nuestra época".

En el preámbulo de la Ley 4/89 se sintetiza el contenido de la nueva norma: "El título I de la Ley relaciona los principios inspiradores de la misma, centrados en la idea rectora de la conservación de la naturaleza, entendida ésta tanto como el medio en el que se desenvuelven los procesos ecológicos esenciales y los sistemas vitales básicos como el conjunto de recursos indispensables para la misma. La utilización de dichos recursos se condiciona a su carácter ordenado y se confía a las Administraciones competentes la vigilancia sobre tal gestión, velando para poder transmitir a las generaciones futuras los recursos naturales susceptibles de satisfacer sus necesidades y aspiraciones. El título concluye con la previsión necesaria de que las actividades encaminadas al logro del objeto de esta Ley puedan ser declaradas de utilidad pública. El título II alude al planeamiento de los recursos naturales y crea, como instrumento novedoso en nuestro ordenamiento jurídico, los Planes de Ordenación de los Recursos Naturales y las Directrices para la Ordenación de los Recursos Naturales. La Ley parte de la firme convicción de que sólo una adecuada planificación de los recursos naturales permitirá alcanzar los objetivos conservacionistas deseados. Los Planes de Ordenación de los Recursos Naturales se configuran por la Ley. Huyendo de pretensiones inviables, como instrumentos flexibles que permitirán, con diverso nivel de intensidad, un tratamiento prioritario e integral en determinadas zonas para la conservación y recuperación de los recursos, espacios naturales y especies a proteger. Las disposiciones contenidas en estos Planes constituirán un límite para cualesquiera otros Instrumentos de ordenación territorial o física, prevaleciendo sobre los ya existentes, condición indispensable si se pretende atajar el grave deterioro que sobre la naturaleza ha producido la acción del hombre. La Ley confiere a las Administraciones Públicas competentes la aprobación de los Planes de Ordenación de los Recursos Naturales, ofreciendo así a las Comunidades Autónomas un importante instrumento para la implementación de sus políticas territoriales. El título III establece el régimen especial para la protección de los espacios naturales. La Ley refunde los regímenes de protección creados por la Ley de 2 de mayo de 1975 en las cuatro categorías de Parques, Reservas Naturales, Monumentos Naturales y Paisajes Protegidos. La declaración y gestión de estos espacios naturales protegidos corresponderá en todo caso a las Comunidades Autónomas en cuyo ámbito territorial se encuentren ubicados. La única reserva que la Ley establece a favor del Estado es la gestión de los denominados Parques Nacionales, integrados en la Red de Parques Nacionales, en virtud de su condición de espacios representativos de alguno de los principales sistemas naturales españoles. La declaración de un espacio como Parque Nacional se realizará mediante Ley de las Cortes Generales, sin perjuicio de la integración automática que, para los Parques Nacionales existentes a la entrada en vigor de esta Ley relacionados en la disposición adicional primera, opera dicha disposición. La voluntad de la Ley de atender no sólo a la conservación y restauración sino a la prevención de los espacios naturales se plasma en el capítulo $\mathrm{V}$ del título III que contempla un régimen de protección preventiva aplicable a zonas bien conservadas actualmente pero amenazadas por un potencial factor de perturbación. El título IV establece las medidas necesarias para garantizar la conservación de las especies de la flora y la fauna 
silvestres, con especial atención a las especies autóctonas. Se racionaliza el sistema de protección atendiendo preferentemente a la preservación de los hábitats y se transponen al ordenamiento jurídico español las Directivas de la Comunidad Económica Europea sobre protección de la fauna y la flora, entre ellas la número 79/409/CEE, relativa a la conservación de las aves silvestres. Se crea el Catálogo Nacional de Especies Amenazadas, dependiente del Ministerio de Agricultura, Pesca y Alimentación, y se prevén los catálogos de especies amenazadas a establecer por las Comunidades Autónomas en sus respectivos ámbitos territoriales. Se regulan, asimismo, en este título la Caza y la Pesca Continental, en su condición de recursos naturales cuya persistencia debe garantizarse, prohibiéndose la captura de especies catalogadas y creándose, como instrumento de planeamiento, los Planes Técnicos justificativos de la cuantía y modalidades de las capturas a realizar, cuyo contenido y aprobación se confía a las Comunidades Autónomas. La Ley establece la necesidad de acreditar la aptitud y conocimientos precisos a través de un examen cuya superación habilitará para obtener la correspondiente licencia de caza o pesca, a expedir por las Comunidades Autónomas. Como instrumento imprescindible para la racional explotación de la riqueza cinegética y piscícola se crea el Censo Nacional de Caza y Pesca en el que se centralizará la información brindada por las respectivas Comunidades Autónomas. Mediante la presente Ley se da respuesta igualmente a uno de los problemas más importantes de los relacionados con la actividad de policía administrativa de la caza y la pesca, como es el de la necesaria coordinación de las competencias sancionadoras de las respectivas Comunidades Autónomas. A tal efecto se crea el Registro Nacional de Infractores de Caza y Pesca, en el que se inscribirán los datos facilitados por las Comunidades Autónomas a partir de sus propios registros de infractores de caza y pesca. Al exigirse el certificado del citado Registro Nacional para la expedición, en su caso, de la correspondiente licencia, se consigue coordinar las actuaciones de las distintas Comunidades Autónomas y extremar la vigilancia para la preservación de los recursos cinegéticos y acuícolas. El título $V$ refleja con plenitud la necesaria cooperación y coordinación que debe lograrse entre el Estado y las Comunidades Autónomas en una materia, la política de conservación de la naturaleza, que nuestra Constitución ha querido compartirla entre las distintas Administraciones Públicas españolas. Se crea a tal fin la Comisión Nacional de Protección de la Naturaleza, órgano consultivo y de cooperación en el que se integrarán la Administración del Estado y las Comunidades Autónomas. Como elemento imprescindible de la política avanzada de conservación de la naturaleza que la presente Ley establece, su título VI recoge un acabado catálogo de infracciones administrativas con sus correspondientes sanciones, sin perjuicio de lo que disponga al respecto la legislación autonómica que desarrolle estas normas de protección u otras normas especiales reguladoras de determinados recursos naturales. Se establece la obligación del infractor de reparar el daño causado, al margen de las sanciones penales o administrativas que en cada caso procedan, teniendo la reparación como objetivo el lograr la restauración del medio natural en la medida de lo posible. Se confiere a las Comunidades Autónomas, sin perjuicio de las competencias de la Administración Central, la imposición de las sanciones previstas en la Ley, que podrán llegar, dada la trascendencia social de los intereses protegidos, hasta la multa de 50.000.000 de pesetas".

Dos aspectos serán esenciales en el devenir de esta Ley y de las normativas que la desarrollan. El primero la regulación de competencias entre el Estado y las Comunidades Autónomas, la segunda el encaje de la Red Natura 2000 y de las normativas europeas en el marco de la conservación y la gestión de los espacios naturales. "El artículo 149.1.23 de nuestra Constitución reserva al Estado la competencia exclusiva para dictar la legislación básica sobre protección del medio ambiente. La presente Ley encuentra asiento sobre dicho título competencial y contiene aquel conjunto de normas que el Estado considera básicas en la materia. A partir de esta definición, que tiene la virtud de superar el actual ordenamiento de origen fundamentalmente preconstitucional, las Comunidades Autónomas podrán desplegar las medidas de conservación de la naturaleza que estatutariamente les competan, en el marco de lo previsto por la presente Ley". (Preámbulo). En ambos casos se generarán múltiples problemas, tanto por incumplimiento de la normativa europea, como por los intentos de la administración en recuperar competencias que deberían asumir las CCAA, especialmente en el ámbito de las aguas marinas y de los Parques Nacionales, disputas que se resolverán en diferentes sentencias judiciales (Sentencia 15/03/1999 TS; Sentencia 194/2004 TC; Sentencia 101/2005, etc).

Las áreas protegidas o espacios protegidos mantienen la denominación legal de "Espacio Natural Protegido" definiéndose como: "Son espacios naturales protegidos: 1. Aquellos espacios del territorio nacional, incluidas las aguas continentales, y los espacios marítimos sujetos a la jurisdicción nacional, incluidas la zona económica exclusiva y la plataforma continental, que contengan elementos y sistemas naturales de especial interés o valores naturales sobresalientes, podrán ser declarados protegidos de acuerdo con lo regulado en esta Ley. 2. La protección de estos espacios podrá obedecer, entre otras, a las siguientes finalidades: a) Constituir una red representativa de los principales ecosistemas y regiones naturales existentes en el territorio nacional. b) Proteger aquellas áreas y elementos naturales que ofrezcan un interés singular desde el punto de vista científico, cultural, educativo, estético, paisajístico y recreativo. c) Contribuir a la supervivencia de comunidades o especies necesitadas de protección, mediante la conservación de sus hábitats. d) Colaborar en programas internacionales de conservación de espacios naturales y de vida silvestre, de los que España sea parte. 3.- La declaración de un espacio como protegido lleva aparejada la de utilidad pública, a efectos expropiatorios de los bienes y derechos afectados, y la facultad de la Administración competente para el ejercicio de los derechos de tanteo $y$ retracto, en las transmisiones onerosas intervivos de terrenos situados en el interior del mismo. A los efectos del ejercicio de los derechos de tanteo y retracto, por el transmitente se notificarán fehacientemente a la 
Administración actuante las condiciones esenciales de la transmisión pretendida y, en su caso, copia fehaciente de la escritura pública en que haya sido instrumentada la citada transmisión. El derecho de tanteo podrá ejercerse en el plazo de tres meses y el de retracto en el de un año, ambos a contar desde la correspondiente notificación, que deberá efectuarse en todo caso y será requisito necesario para inscribir la transmisión en el Registro de la Propiedad "(art. 10).

En función de los bienes y valores a proteger, los espacios naturales protegidos se clasifican en 4 categorías: Parques, Reservas Naturales, Monumentos Naturales, Paisajes Protegidos. Los Parques: 1. Los Parques son áreas naturales, poco transformadas por la explotación u ocupación humana que, en razón a la belleza de sus paisajes, la representatividad de sus ecosistemas o la singularidad de su flora, de su fauna o de sus formaciones geomorfológicas, poseen unos valores ecológicos, estéticos, educativos y científicos cuya conservación merece una atención preferente. 2.- En los Parques se podrá limitar el aprovechamiento de los recursos naturales, prohibiéndose en todo caso los incompatibles con las finalidades que hayan justificado su creación. 3.- En los Parques se facilitará la entrada de visitantes con las limitaciones precisas para garantizar la protección de aquéllos (art. 13). Reservas Naturales: 1.- Las Reservas Naturales son espacios naturales, cuya creación tiene como finalidad la protección de ecosistemas, comunidades o elementos biológicos que, por su rareza, fragilidad, importancia o singularidad merecen una valoración especial. 2.- En las Reservas estará limitada la explotación de recursos, salvo en aquellos casos en que esta explotación sea compatible con la conservación de los valores que se pretenden proteger. Con carácter general estará prohibida la recolección de material biológico o geológico, salvo en aquellos casos que por razones de investigación o educativas se permita la misma previa la pertinente autorización administrativa (art. 14). Monumentos Naturales: 1.- Los Monumentos Naturales son espacios o elementos de la naturaleza constituidos básicamente por formaciones de notoria singularidad, rareza o belleza, que merecen ser objeto de una protección especial. 2.- Se considerarán también Monumentos Naturales, las formaciones geológicas, los yacimientos paleontológicos y demás elementos de la gea que reúnan un interés especial por la singularidad o importancia de sus valores científicos, culturales o paisajísticos (art. 16). Paisajes protegidos: Los Paisajes Protegidos son aquellos lugares concretos del medio natural que, por sus valores estéticos y culturales, sean merecedores de una protección especial (art. 17).

La Ley 4/89 contempla por primera vez en la normativa española la necesidad de establecer un instrumento de gestión en los espacios naturales, el Plan de Ordenación de los Recursos Naturales (PORN). Indicando: 1. La declaración de los Parques y Reservas exigirá la previa elaboración y aprobación del correspondiente Plan de Ordenación de los Recursos Naturales de la zona. 2. Excepcionalmente, podrán declararse Parques y Reservas sin la previa aprobación del Plan de Ordenación de los
Recursos Naturales, cuando existan razones que lo justifiquen y que se harán constar expresamente en la norma que los declare. En este caso deberá tramitarse en el plazo de un año, a partir de la declaración de Parque o Reserva, el correspondiente Plan de Ordenación (art. 15).

Otro aspecto igualmente novedoso de la Ley 4/89 es la posibilidad de establecer zonas periféricas de protección en los Espacios Naturales Protegidos: 1. En los Espacios Naturales Protegidos declarados por Ley se podrán establecer Zonas Periféricas de Protección destinadas a evitar impactos ecológicos o paisajísticos procedentes del exterior. Cuando proceda, en la propia Ley de creación, se establecerán las limitaciones necesarias. 2. Con el fin de contribuir al mantenimiento de los espacios naturales protegidos, y compensar socioeconómicamente a las poblaciones afectadas, en sus disposiciones reguladoras podrán establecerse Áreas de Influencia Socioeconómica, con especificación del régimen económico y compensación adecuada al tipo de limitaciones. Estas áreas estarán integradas por el conjunto de los términos municipales donde se encuentre ubicado el espacio natural de que se trate y su Zona Periférica de Protección (art. 18). Una herramienta útil que sin embargo ha tenido un escaso uso en el territorio español en contraste con su empleo en otros países europeos o americanos.

A mayores del PORN, los Parques deberán contar también con un segundo instrumento, el Plan Rector de Uso y Gestión (PRUG), definido en sus contenidos en la propia Ley: 1. Por los órganos gestores de los Parques se elaborarán Planes Rectores de Uso y Gestión, cuya aprobación corresponderá, en cada caso, al Gobierno de la Nación o a los órganos competentes de las Comunidades Autónomas. Las Administraciones competentes en materia urbanística informarán preceptivamente dichos Planes antes de su aprobación. En estos Planes, que serán periódicamente revisados, se fijarán las normas generales de uso y gestión del Parque. 2. Los Planes Rectores prevalecerán sobre el planeamiento urbanístico. Cuando sus determinaciones sean incompatibles con las de la normativa urbanística en vigor, ésta se revisará de oficio por los órganos competentes (art. 19).

Finalmente se mantienen en los Espacios Naturales los órganos de participación en términos muy similares a los establecidos por la normativa franquista: Para colaborar en la gestión de los Espacios Naturales Protegidos se podrán constituir, como órganos de participación, Patronatos o Juntas Rectoras, cuya composición y funciones se determinarán en sus disposiciones reguladoras (art. 19).

La política de conservación de la naturaleza de la Comisión Económica Europea se visualiza inicialmente a través de la Directiva Aves (Directiva 79/409/CEE), reforzándose y consolidándose posteriormente con la aprobación de la Directiva Hábitats (Directiva 92/43/CEE), que constituye la red de espacios protegidos europeos, la Red Natura 2000. En disposiciones comunitarias posteriores la Red Natura quedará integrada en el resto de las políticas territoriales y ambientales. Ambas Directivas tendrán diferentes modificaciones que pueden consultarse en el servidor EuroLex de la Comisión Europea. Las modificaciones más 
importantes se refieren en el caso de la Directiva Hábitat a la adecuación de sus distintos anexos, acorde con el desarrollo científico-técnico (Directiva 97/62/CE), mientras que el caso de la Directiva Aves, se planteó una reforma más sustancial de su texto (Directiva 2009/147/CE).

El modelo de conservación de la naturaleza planteado desde la Comisión se estructuraba en tres pilares básicos: los espacios de la Red Natura 2000 (Lugares de Importancia Comunitaria, LIC, Zonas de Especial Conservación, ZEC, Zonas de Especial Protección para las Aves, ZEPA), los ecosistemas designados y codificados como tipos de hábitats naturales y seminaturales, y las especies de flora y fauna silvestre. La designación de los espacios se planteaba a partir de criterios técnicos centrados en el estado de conservación de los hábitats y de las especies. E igualmente se planteaban sencillas pero tajantes medidas para asegurar su conservación y uso sostenible a través del artículo 6 de la Directiva Hábitat (CE, 2000). Otro aspecto novedoso, para muchos de los países europeos y concretamente para el ámbito español, ,era la existencia de procesos de evaluación periódica de las medidas de conservación y en consecuencia de las actividades que se realizaban y autorizaban sobre los elementos de la Red Natura 2000. Como hemos indicado, la Comisión Europea, integro plenamente la Red Natura en el conjunto de su elenco normativo, especialmente en la normativa de impacto ambiental, planteando además la no cofinanciación con fondos europeos de actuaciones que pudiesen incidir de forma negativa sobre los componentes de la Red Natura 2000.

La transposición y creación de la Red Natura 2000 en el estado español se hizo a trompicones (Real Decreto 1997/1995; Real Decreto 1193/1998; Real Decreto 1241/2006, Ley 42/2007), el nuevo modelo era rechazado frontalmente por distintos sectores de la administración central, especialmente en el ámbito de montes y de agricultura, así como también era rechazado por algunas Comunidades Autónomas que planteaban la persistencia de los viejos espacios naturales declarados por el franquismo que en muchos casos incumplían las condiciones técnicas fijadas por la Comisión, a la vez que se mostraban contrarios a lo que consideraban como una primacía de los objetivos de conservación con las potencialidades de producción o explotación del medio. La falta de miras de la clase política española llevo a una lenta y tortuosa transposición de la Directiva Aves y especialmente de la Directiva Hábitat, tratando de descafeinar y alterar sus fines y objetivos. Este lamentable proceso se materializa en Galicia en distintas propuestas de Lugares de interés Comunitario que conformadas por el Gobierno de la Xunta de Galicia y trasladas a Bruselas por el Ministerio, son consideradas por la Comisión como insuficientes. La dilación de este proceso y la no aplicación de un régimen cautelar a la áreas que deberían integrar la Red Natura 2000, llevo en muchos casos a su alteración o destrucción, vinculada con la construcción de Parques Eólicos, concentraciones parcelarias, creación de infraestructuras, urbanizaciones, etc. Una forma indignante se esquivar la normativa europea y permitir la destrucción de la biodiversidad para favorecer el lucro de unos pocos.
La primera normativa gallega de conservación de la naturaleza

En esta nueva etapa, Galicia acorde con la Constitución (CE, 1978) se había dotado de un Estatuto de Autonomía (Ley Orgánica 1/1981), y se habían materializado las transferencias de competencias entre el Estado y la Comunidad Autónoma de Galicia que incluían entre otras las relativas al medio ambiente y a la conservación de la naturaleza. Las primeras actuaciones en materia de conservación de la naturaleza por parte de la Xunta de Galicia se realizan en base a la normativa estatal, pero sin una clara estrategia, de modo que algunas actuaciones, como la declaración de nuevos Parques Naturales o de Monumentos Naturales se realizan en función de los criterios y categorías de la Ley $4 / 89$, como es el caso del Parque Natural el complejo dunar de Corrubedo y lagunas de Carregal y Vixán (Decreto 139/1992; Decreto 148/1992)

Mientras que para otros casos se plantea un modelo provisional y paralelo a dicha normativa con la creación del Registro de Espacios Naturales en Régimen de Interés General, RENRIG (Decreto, 82/1989), planteado como un paso previo a la declaración de los espacios en una de las categorías contempladas en la Ley 4/89. La inclusión de un espacio en el registro permitía aplicarle un régimen de protección para salvaguardar sus valores. Aunque este en la mayoría de los casos este régimen de protección preventivo no fue convenientemente aplicado, permitiendo en los mismos distintas de actuaciones adversas a sus componentes ambientales, mientras que se alargaba el trámite para su definitiva declaración, cuando no quedaban finalmente excluidos de la misma, como aconteció sorprendentemente con la propuesta del Río Sor Una tercera vía, proviene del ámbito de la ordenación del territorio y se materializa con un conjunto de "Espacios Naturales", delimitados y designados en las Normas Complementarias y Subsidiarias del Planeamiento de Galicia (Orden 14/5/1991 de 14 de mayo), Tanto en el caso de los espacios del RENRIG (Decreto, 82/1989), como los contemplados en las Normas Complementarias, la protección real de los componentes de la biodiversidad no resulta muy efectiva, y en la mayoría de ellos se producen tras su declaración pérdidas significativas de superficies de hábitats naturales-seminaturales, así como de individuos de especies endémicas, raras o amenazas en el contexto gallego, algunas de ella vinculada a proyectos impulsados desde la propia administración autonómica.

La indefinición de la Ley 4/89 en relación con el estatus jurídico de la Red Natura 2000 y la necesidad de conservación los hábitats y especies de interés comunitario planteado en la Directiva Aves y la Directiva Hábitats, lleva en el caso gallego a una farragosa tramitación de la propuesta de Lugares de Interés Comunitario y de las Zonas de Especial Protección de las Aves, cuyo análisis trataremos de abordar en un próximo trabajo. Sintetizando este propuesto, cabe resaltar que las propuestas iniciales elaboradas por la Xunta de Galicia a través del SITGA y sobre la base de los inventarios de hábitats y especies realizados por el Ministerio de Agricultura, fueron excesivamente mínimas, incumpliendo los criterios de 
representatividad fijados por los grupos de expertos de la Comisión Europea generando un largo y tedioso proceso modificaciones, ampliaciones y aprobaciones parciales, que fue aprovechado para impulsar en determinados territorios proyectos que resultaban contrarios a los objetivos de la Red Natura 2000 o exigían un procedimiento de evaluación ambiental (autovías, parques eólicos, minicentrales, canteras, etc), a las que se dio vía libre, menoscabando la importancia y la necesidad de la conservación de la naturaleza.

Doce años después de la aprobación de la Ley 4/1989 por parte del Estado, la Xunta de Galicia aprueba en el año 2001, su primera ley de conservación de la naturaleza, la Ley 9/2001 de Conservación de la Naturaleza. Se trata de un texto reducido. Sin objetivos claros que tampoco incluye una diáfana estrategia para afrontar los inquietantes problemas que están a incidir de forma negativa sobre la conservación de los ecosistemas, los paisajes y las especies silvestres de Galicia. En cuanto a espacios naturales. Crea una Red sin darle objetivos, ni funciones a la misma.

Según el legislador la Ley 9/2001: "La presente Ley enfatiza la incorporación al derecho gallego de los principios emanados de la Conferencia de Río, en cuanto a la gestión sostenible de los recursos naturales, y asumiendo en especial los principios de subsidiariedad, al acercar las decisiones al nivel más cercano al ciudadano, sin implicar por ello una pérdida de efectividad de la política pública, y de responsabilidad compartida, al buscar una mayor coordinación de los agentes públicos y privados" (preámbulo), considerando que "La preservación de la diversidad biológica, asumida por la Cumbre de Río de Janeiro en 1992, se incorpora decisivamente al derecho comunitario a través de la Directiva 92/43/CEE, relativa a la conservación de los hábitats naturales y de la flora y fauna silvestres, si bien una gran parte de sus objetivos estaban ya programados a través de disposiciones comunitarias anteriores". Salvo esta alusión indirecta la Ley 9/2001 no contempla ninguna referencia en el preámbulo a la Red Natura 2000, aprobada por la referida Directiva 92/43/CEE. Mientras que en el articulado la única mención a la Red Natura 2000 se confina al artículo 16, referido a las Zonas de especial protección de los valores naturales. El concepto de naturaleza empleado por el legislador gallego muestra la prevalencia de las especies sobre los ecosistemas (paisajes, hábitats), a la vez que margina los componentes de la geodiversidad (geológicos, geomorfológicos, paleontológicos, etc).

La Ley 9/2001, incluye 4 título y 12 capítulos, que comprenden 74 artículos. Incluyendo además 9 Disposiciones adicionales. 3 Disposiciones transitorias, 1 Disposición derogatoria, 2 Disposiciones finales El título preliminar define el objeto y los principios inspiradores de la Ley, donde no figura la Red Natura 2000. El título I, De los espacios naturales, define con carácter general los espacios naturales que han de considerarse merecedores de una protección especial, establece sus categorías, regula su procedimiento de declaración y dispone el régimen general de protección de estos, contemplándose la posibilidad de establecer regímenes de protección preventiva. El título II,
De la fauna y flora, establece las medidas necesarias para garantizar la conservación de los hábitats naturales y especies de la flora y fauna, con especial atención a las especies autóctonas y las amenazadas, para lo que se crea, en conformidad con la normativa estatal, el Catálogo gallego de especies amenazadas y el Registro de especies de interés gallego, de tal forma que el proceso de catalogación incorpora medidas positivas por parte de la Administración autonómica gallega para remediar los factores de amenaza sobre las especies de flora y fauna silvestres. Asimismo, el interés científico, estético o monumental y ornamental de algunos especímenes de cualquier especie botánica existentes en Galicia aconseja que las normas protectoras deban hacerse extensivas a este tipo de árboles o especímenes de la flora. El título III de la Ley, De las infracciones y sanciones, recoge el régimen sancionador sobre espacios naturales, la flora y la fauna derivado del establecido por la Ley 4/89.

La Ley 9/2001 prevé ocho tipos de regímenes de protección, cuatro ya existentes en la normativa estatal: Reservas Naturales, Parques, Monumentos Naturales, Paisajes Protegidos. Y otras cuatro categorías definidas en la propia normativa gallega: Humedales Protegidos, Zonas de Especial Protección de los Valores Naturales (ZEPVN), Espacios Naturales de Interés Local (ENIL) y Espacios Privados de Interés Natural (EPIN), en atención a los recursos naturales o biológicos y a los valores que contengan.

En cuanto a las definiciones de los cuatro primeros se mantienen en gran medida los mismos criterios que los contemplados en la normativa estatal: Reserva Natural: 1.Las reservas naturales son espacios naturales cuya declaración tiene como finalidad la protección de ecosistemas, comunidades o elementos biológicos que, por su rareza, fragilidad, importancia o singularidad, merecen una valoración especial. En las reservas estará limitada la explotación de recursos, salvo en aquellos casos en que esta explotación se considere compatible con la conservación de los valores que pretenden protegerse. Con carácter general, estará prohibida la recolección de material biológico o geológico, con excepción de aquellos casos en que por razones de investigación, educativas o de conservación se permita la misma, previa autorización administrativa. 2.- Aquellas reservas naturales que contengan ecosistemas o comunidades en estado de conservación que requieran una protección absoluta podrán ser declaradas reservas naturales integrales. En estas zonas está prohibido cualquier tipo de aprovechamiento y se restringirá el acceso público, funcionando el sistema con la mínima intervención exterior posible, salvo las necesarias medidas de conservación, gestión y, en su caso, investigación (art. 11). Parque: 1.- Los parques son áreas naturales, poco transformadas por las actividades humanas, que, en razón de la belleza de sus parajes, de la representatividad de sus ecosistemas o la singularidad de su flora, fauna o formaciones geomorfológicas, poseen unos valores ecológicos, estéticos, educativos o científicos cuya conservación merece una atención preferente. 2.- En los parques podrá limitarse los aprovechamientos de los recursos naturales, prohibiéndose en todo caso los 
incompatibles con las finalidades que hubieran justificado su creación. 3.- En los parques se facilitará la entrada de visitantes con las limitaciones que sean precisas para garantizar la conservación de los valores naturales. 4.- Los parques podrán ser naturales o nacionales (artículo 12). Monumento Natural: 1.- Los monumentos naturales son espacios o elementos de la naturaleza constituidos básicamente por formaciones de notoria singularidad, rareza o belleza que merecen ser objeto de una protección especial. Se consideran también monumentos naturales las formaciones geológicas y demás elementos de la gea, así como los yacimientos paleontológicos, que reúnan un interés especial por la singularidad o importancia de sus valores científicos, culturales o paisajísticos. 2.- En los monumentos naturales sólo se admitirán los usos o actividades que no pongan en peligro la conservación de los valores que motivaron su declaración (art. 13). Paisaje Protegido: 1.- Los paisajes protegidos son espacios que, por sus valores singulares, estéticos y culturales o bien por la relación armoniosa entre el hombre y el medio natural, sean merecedores de una protección especial. 2.- El régimen de protección de los paisajes protegidos estará dirigido expresamente a la conservación de las relaciones y procesos, tanto naturales como socioeconómicos, que han contribuido a su formación y hacen posible su pervivencia (art. 15).

Mientras que para la definición de Humedal Protegido se recurre a la establecida en el Convenio de Ramsar de 1971, definiéndolo en la norma gallega como: 1.- Se entenderá por humedal protegido las extensiones de marismas, pantanos, turberas o superficies cubiertas de agua, sean éstas de régimen natural o artificial, permanentes o temporales, estancadas o corrientes, dulces, salobres o saladas, incluidas las extensiones de agua marina cuya profundidad en marea baja no exceda de seis metros, que a la vez cumplan una función de importancia internacional, nacional o autonómica en la conservación de los recursos naturales, y que sean declaradas como tales. Podrán comprender zonas ribereñas, costeras o adyacentes, así como las islas o extensiones marinas de profundidad superior a los seis metros en marea baja cuando éstas se encuentren dentro del humedal. 2.- En los humedales protegidos podrá limitarse los aprovechamientos de los recursos naturales, prohibiéndose en todo caso los incompatibles con las finalidades que hubieran justificado su declaración (art. 14).

La Zona de especial protección de los valores naturales (ZEPVN), constituyen una fondo de armario para albergar a los espacios de la Red Natura 2000, así como a otros espacios que no se adecuen a las características anteriores según la discrecionalidad del gobierno. Las ZEPVN se definen como. 1.- Se considera como zona de especial protección de los valores naturales aquellos espacios por cuyos valores o interés natural, cultural, científico, educativo o paisajístico sea necesario asegurar su conservación y no tengan otra protección específica, sin perjuicio de lo dispuesto en el artículo 9 de la presente Ley. 2.- En estas áreas podrá seguirse llevando a cabo de manera ordenada los usos y actividades tradicionales que no vulneren los valores protegidos. Para el resto de las actuaciones, incluyendo la realización de edificaciones, será precisa la autorización de la Consejería de Medio Ambiente. 3.- Se incluirán también las zonas especiales de conservación que conforman la Red Natura 2000, creada al amparo de las Directivas CEE 79/409 y 92/43, y que no posean otra figura de protección de las contempladas en la presente Ley (art. 16).

Finalmente, las otras dos categorías de espacios naturales protegidos (ENIL, EPIN) tienen paralelismos con otras figuras contempladas en normativas autonómicas o de diferentes países de europeos y americanos, que se designan con excesiva discrecionalidad. Espacio natural de interés local (ENIL). 1.- A petición del ayuntamiento $y$ previo del informe de la Consejería de Política Territorial, Obras Públicas e Vivienda, la Consejería de Medio Ambiente podrá declarar como espacios naturales de interés local a aquellos espacios integrados en su término municipal que por sus singularidades sean merecedores de algún tipo de protección de sus valores naturales. 2.- La responsabilidad y competencia en la gestión de estos espacios será municipal, y no se considerarán incluidos en la Red gallega de espacios protegidos. 3.- Su declaración como tales no implicará la asignación de recursos de la Comunidad Autónoma, si bien podrán tener preferencia en la obtención de ayudas para su conservación y gestión (art. 17). Espacio privado de interés natural (EPIN): 1.- Las instituciones y los propietarios particulares de los terrenos en que existan formaciones naturales, especies o hábitats de flora y fauna silvestres cuya protección se considere de interés podrán proponer a la Consejería de Medio Ambiente, mediante la presentación de una memoria suficientemente motivada, su declaración como espacio privado de interés natural. 2. - La declaración supone el compromiso formal del promotor de poner en práctica las medidas precisas para la conservación de los valores naturales que lo motivaron. 3.Estos espacios no se incluirán en la Red gallega de espacios naturales protegidos. 4.- Su declaración no implicará la obligatoriedad, por parte de la Consejería de Medio Ambiente, de aportar recursos públicos, si bien podrán tener preferencia en la concesión de ayudas y subvenciones (art. 18).

La Ley 9/2001 establece como instrumento de ordenación de los espacios naturales los ya establecidos por la normativa estatal, los PORN y los PRUG, añadiendo un instrumento propio, el Plan de Conservación, planteado para las categorías de espacios naturales protegidos creados por la norma autonómica. La norma mantiene la existencia de un órgano colegiado consultivo para canalizar la participación de los intereses sociales y económicos afectados, excepto en los casos cuya gestión sea asumida directamente por los servicios de la consejería competente.

El artículo 10 de la Ley 9/2001 crea la Red gallega de espacios protegidos, considerando que: 1.- Bajo la competencia de la Comunidad Autónoma de Galicia, se crea la Red gallega de espacios protegidos, en la cual estarán representados los principales ecosistemas, paisajes o hábitats gallegos y que contendrá aquellos lugares necesarios para asegurar su conservación. 2.- La Red gallega de espacios protegidos estará constituida por 
aquellos espacios protegidos que se declaren en alguna de las categorías del artículo 8.1, excepto las de los apartados h) e i). (art. 10).

La Red de Espacios Naturales Protegidos de Galicia carece de objetivos y líneas de actuación concreta equiparable a la existente en otros tipos de espacios naturales. Redes que a partir de un exhaustivo análisis territorial y ambiental, evalúan los espacios declarados y el conjunto del territorio para definir un conjunto de unidades en(zona núcleo, corredores, zonas buffer, etc), y eficiencia, representatividad, contribución a la red, fragilidad, dinámica, proponiendo en su caso reformulación o incluso de nuevas unidades. Una red de área protegida debe partir de unos objetivos y una líneas de actuación claramente definidas, con una programación de actuaciones y una delimitación de indicadores de seguimientos. La Red Gallega se reduce a una imagen institucional que se modifica a medida que se modifican los cargos que asumen las competencias en medio ambiente.

Tras la aprobación de la Ley 9/2001 de Conservación de la Naturaleza, se produjo un incremento en el número de espacios naturales protegidos declarados en Galicia. De las 8 categorías de Espacios Naturales se declarando espacios en todas, salvo en la de Reserva Natural. Siendo la ZEPVN la figura con mayor número de espacios y la que mayor superficie comprende en Galicia. La figura de ZEPVN fue empleada para designar a los espacios de la Red Natura 2000, declarado por la Xunta de Galicia, una opción diferente a la de otras Comunidades Autónomas que prefirieron mantener a los espacios de las Red Natura 2000 en una nebulosa jurídica. En consecuencia, en Galicia la Red Natura posee el estatus jurídico vinculado a la condición de "Espacio Natural Protegido", que trasciende desde el ámbito de la conservación de la naturaleza, al Código Penal, a la normativa territorial y urbanística, agrícola, forestal, pesquera, etc. Dada la posibilidad de que en un mismo territorio pueden concurrir dos o más categorías de áreas protegidas los espacios de la Red Natura 2000 resultan coincidentes con la casi totalidad de la superficie declarada como Parque y la mayor parte de los Monumentos Naturales. En el año 2014, se aprobó el Plan Director de la Red Natura 2000 de Galicia, que se corresponden con la figura de un Plan de Ordenación de los Recursos Naturales, y que es de aplicación para todos los espacios autonómicos (Decreto 37/2004). La aprobación del Plan Director conlleva que la mayoría de los Espacios Naturales Protegidos declarados por la Xunta de Galicia, posean un instrumento de gestión.

En cuanto a los Parques, el gobierno de la Xunta de Galicia declaró, amparándose en la Ley 9/2001 y la Ley 4/89, en el periodo comprendido entre 1992-2002, cuatro nuevos Parques Naturales: O Invernadeiro (155/1997); Fragas do Eume (Decreto 218/1997), Serra da Enciña da Lastra (Decreto 157/2002); Baixa Limia-Serra do Xurés (Decreto 401/2009), no culminando la declaración de Parque Natural de Os Ancares - O Courel (Orden 14/02/2001) o desatendiendo la petición popular para designa el Monte Pindo como Parque Natural (Maceiras, 2012). Mientras que el Gobierno de España, llevó a cabo la declaración del Parque Nacional Marítimo-Terrestre das Illas Atlánticas de Galicia (Ley 15/2002), la declaración supuso de facto la anulación del Parque Nacional das Illas Cíes, aunque en la normativa de declaración no se recoge expresamente la derogación de esta.

Junto a la Red Gallega de Espacios Naturales se han establecido subredes. La primera fue la Red de Parques Naturales de Galicia (Decreto 148/2007, do 19 de julio, por el que se determina la creación, composición y funcionamiento del Consejo de la Red de Parques Naturales de Galicia), que tras unas reuniones iniciales y un importante dispendio en comunicación e imagen de marca termino languideciendo sin llegar a anularse. El desconcierto de la administración autonómica determinó que en el año 2016, el Diario Oficial de Galicia, publicará el Decreto 69/2016, de 19 de mayo, por el que se crea la Red de parques Naturales de Galicia, sin haber derogado el anterior. La nueva Red, resulta igualmente inoperante quedando de nuevo reducida su actividad a diseñar una nueva imagen corporativa con el consiguiente gasto de recursos públicos en modificar todo tipo de carteles y materiales.

La existencia de dos Rede de Parques Naturales Gallegos puede parecer una extravagancia, pero no es más que la punta de un iceberg de una desastrosa gestión de la naturaleza y de los espacios protegidos que se agudiza entre 2009-2014, situando a Galicia en el furgón de cola de la política ambiental. Son muchos los elementos que justifican esta dura pero realista valoración, entre ellos cabe resaltar la decisión política de congelar la ampliación de la Red Natura 2000 de Galicia (Anuncio de 21/12/2011), que de acuerdo con las exigencias de la Comisión Europea debería mejorar la presentación determinados tipos de hábitats prioritarios tanto en los territorios adscritos a la Región Mediterránea como principalmente en la Región Atlántica, aunque el gobierno autónomo aposto por una escueta propuesta (Eirexas Santamaria, 2012). La congelación del trámite y la falta de aplicación de medidas de conservación para las áreas designadas como futuros LIC/ZEC propicio que en las mismas se llevaran a cabo actuaciones que supusieron la alteración, cuando no la total destrucción de los hábitats prioritario, una forma de actuar que resulta totalmente irracional. Otra punta del Iceberg fue la decisión política llevada a cabo en el año 2013, para anular la figura de Director de Parque Natural. Un puesto que habitualmente recaía entre el personal técnico de los servicios provinciales, donde en la mayoría de los casos con grandes esfuerzos personales, y pocos medios se doto a los Parques Naturales Gallego de actuaciones y actividades homologables al resto de los Parques Naturales de la Unión Europea. El cambio de rumbo, vino marcado por la designación de un único responsable para la gestión de todos los Parques Naturales, un puesto ocupado por eventuales comisarios políticos que alejan la gestión de los parques gallegos de los objetivos asignados a estos singulares espacios. 
Una nueva norma estatal para la conservación de la naturaleza imbricada en la políticas internacionales y europeas

La falta de previsión o de intención de asumir la normativa de la Unión Europea en materia de medio ambiente y especialmente la referida a la Red Natura 2000, unida a las constantes disputada de competencias y criterios entre la administración general del Estado y los responsables ambientales de la Comunidades Autónomas, fueron poniendo en evidencia que la Ley $42 / 1987$ no era el instrumento más adecuado para resolver y armonizar esta situación. Los responsables del Gobierno de España plantean en consecuencia su reforma iniciando un largo periodo de debate y discusión, en el que intervienen tanto los representantes de las CCAA, como colectivos ambientalistas, científicos y representantes de distintas entidades socioeconómicas. Las discusiones adquieren una mayor virulencia durante el trámite parlamentario incluyendo grandes manifestaciones de agricultores y cazadores opuestos a ciertas medidas de protección y gestión ambiental que consideran lesivas para sus intereses, entre ellas la prohibición relativa a la tenencia y uso de munición de plomo en la práctica de la caza en determinados espacios y ecosistemas.

En diciembre de 2007 el BOE publica finalmente la Ley 42/2007 Patrimonio Natural y de la Biodiversidad, que sustituye y deroga la Ley 4/1989, sobre la que gravito, durante un periodo de más de 30 años, la política de conservación de la naturaleza de España. Una norma sustentado en la incorporación al ordenamiento jurídico española de los convenios multilaterales relativos a distintos materias ambientales (humedales, especies amenazadas, tráfico internacional de especies silvestres, especies migratorias, patrimonio natural), que tuvo una difícil adaptación a los objetivos y obligaciones derivados de la incorporación de España a la Comunidad Económica Europea (Ley Orgánica 10/1985) y especialmente a la Red Natura 2000 (Directiva Aves, Directiva Hábitat). Una norma que a su vez suministró las columna para edificar la articulación normativa en las distintas Comunidades Autónomas. Marcos de acción que la Ley 42/2007 pretenden mejorar y fortalecer, mejorando la transposición y articulación de la normativa europea, y garantizando a las generaciones futuras un Patrimonio Natural y una Biodiversidad mejor conservadas y protegidas.

Los principios inspiradores de la Ley 42/2007, se centran: en la prevalencia de la protección ambiental sobre la ordenación territorial y urbanística; en la incorporación del principio de precaución en las intervenciones que puedan afectar a espacios naturales y/o especies silvestres; en contribuir a impulsar procesos de mejora en la sostenibilidad del desarrollo asociados a espacios naturales protegidos; en la promoción de la utilización ordenada de los recursos para garantizar el aprovechamiento sostenible del patrimonio natural; y en la integración de los requerimientos de la conservación, uso sostenible, mejora y restauración del patrimonio natural y la biodiversidad en las políticas sectoriales. Por último, también se considera como principio básico la garantía de la información y participación de los ciudadanos en el diseño y ejecución de las políticas públicas, incluida la elaboración de disposiciones de carácter general dirigidas a la consecución de los objetivos de la Ley $42 / 2007$.

En el preámbulo de la Ley 42/2007, se considera que el patrimonio natural y la biodiversidad desempeñan una función social relevante por su estrecha vinculación con la salud y el bienestar de las personas, y por su aportación al desarrollo social y económico, por lo que la presente ley establece que las actividades encaminadas a la consecución de sus fines podrán ser declaradas de utilidad pública o interés social, a todos los efectos, $y$, en particular, a los efectos expropiatorios respecto de los bienes 0 derechos que pudieran resultar afectados. También se dispone la preferencia de los acuerdos voluntarios con propietarios y usuarios, en materia de planificación y gestión de espacios naturales protegidos y especies amenazadas. Igualmente se establece la obligación de que todos los poderes públicos, en sus respectivos ámbitos competenciales, velen por la conservación y la utilización racional del patrimonio natural en todo el territorio nacional y en las aguas marítimas bajo soberanía o jurisdicción española, incluyendo la zona económica exclusiva y la plataforma continental, con independencia de su titularidad o régimen jurídico, y teniendo en cuenta especialmente los hábitats amenazados y las especies silvestres en régimen de protección especial. Además, la Ley 42/2007 recoge las competencias de la Administración General del Estado sobre biodiversidad marina.

La Ley 42/2007, establece que las Administraciones Públicas deben dotarse de herramientas que permitan conocer el estado de conservación del patrimonio natural y de la biodiversidad española, y las causas que determinan sus cambios; con base en este conocimiento podrán diseñarse las medidas a adoptar para asegurar su conservación, integrando en las políticas sectoriales los objetivos y las previsiones necesarios para la conservación y valoración del patrimonio natural, la protección de la biodiversidad, la conservación y el uso sostenible de los recursos naturales, y el mantenimiento, y en su caso la restauración, de la integridad de los ecosistemas. Igualmente, se considera como obligación de las Administraciones Públicas promover la participación y las actividades que contribuyan a alcanzar los objetivos de la Ley $42 / 2007$; identificar y eliminar o modificar los incentivos contrarios a la conservación del patrimonio natural y la biodiversidad; promover la utilización de medidas fiscales para incentivar las iniciativas privadas de conservación de la naturaleza; y fomentar la educación e información general sobre la necesidad de proteger las especies de flora y fauna silvestres y de conservar sus hábitats, así como potenciar la participación pública, a cuyo fin se crea el Consejo Estatal para el Patrimonio Natural y la Biodiversidad.

Adicionalmente, la conservación del patrimonio natural y de la biodiversidad exige disponer de mecanismos de coordinación y cooperación entre la Administración General del Estado y las Comunidades autónomas, para lo que la Ley 42/2007 establece la obligación de suministrarse mutuamente la información precisa para garantizar el cumplimiento de los objetivos contemplado en la Ley 
42/2007 y, para ejercer las funciones que venía desarrollando la Comisión Nacional de Protección de la Naturaleza y las nuevas establecidas por la Ley 42/2007, se crea la Comisión Estatal para el Patrimonio Natural y la Biodiversidad como órgano consultivo y de cooperación en materia de protección del patrimonio natural y la biodiversidad entre el Estado y las Comunidades autónomas, cuyos informes o propuestas serán sometidos para aprobación o conocimiento, a la Conferencia Sectorial de Medio Ambiente.

En la versión original, el conjunto de objetivos e instrumentos contemplado en la Ley 42/2007, se articulan a través de seis Títulos, uno de ellos preliminar, 16 Capítulos y 79 artículos, así como 7 Disposiciones adicionales, 3 Disposiciones transitorias, 1 Disposición derogatoria, 5 Disposiciones finales y 8 anexos que incorporan los contenidos en la Directiva 79/409/CEE del Consejo, de 2 de abril de 1979, relativa a la conservación de las aves silvestres, y en la Directiva 92/43/CEE del Consejo, de 21 de mayo de 1992, relativa a la conservación de los hábitats naturales y de la fauna y flora silvestres.

El primer Título de la Ley 42/2007, define los Instrumentos para el conocimiento y la planificación del patrimonio natural y de la biodiversidad. El Capítulo I, crea el Inventario Español del Patrimonio Natural y de la Biodiversidad como instrumento para recoger la distribución, abundancia, estado de conservación y la utilización de dicho patrimonio natural, con especial atención a los elementos que precisen medidas específicas de conservación, o hayan sido declarados de interés comunitario; en particular, en el Inventario se recogerán los distintos catálogos e inventarios definidos en la presente ley y un sistema de indicadores para conocer de forma sintética el estado y evolución de nuestro patrimonio natural. El Capítulo II hace referencia al Plan Estratégico Estatal del Patrimonio Natural y de la Biodiversidad, cuya finalidad es el establecimiento y la definición de objetivos, criterios y acciones que promuevan la conservación, el uso sostenible $y$, en su caso, la restauración del patrimonio, recursos naturales terrestres y marinos y de la biodiversidad. El Capítulo III alude al planeamiento de los recursos naturales y mantiene como instrumentos básicos del mismo los Planes de Ordenación de los Recursos Naturales (PORN) y las Directrices para la Ordenación de los Recursos Naturales, creados en la Ley $4 / 1989$, perfilando los primeros como el instrumento específico de las Comunidades autónomas para la delimitación, tipificación, integración en red y determinación de su relación con el resto del territorio, de los sistemas que integran el patrimonio y los recursos naturales de un determinado ámbito espacial. Las disposiciones contenidas en estos Planes constituirán un límite de cualesquiera otros instrumentos de ordenación territorial o física, prevaleciendo sobre los ya existentes, condición indispensable si se pretende atajar el grave deterioro que sobre la naturaleza ha producido la acción del hombre. Las Directrices para la Ordenación de los Recursos Naturales dictadas por el Gobierno, establecerán los criterios y normas básicas que deben recoger los planes de las Comunidades autónomas para la gestión y uso de los recursos naturales. Todos los instrumentos de planificación considerados en este Título I incluirán, necesariamente, trámites de información pública y de consulta a los agentes económicos y sociales, a las Administraciones Públicas afectadas y a las organizaciones sin fines lucrativos que persigan el logro de los objetivos de Ley 42/2007, así como, en su caso, la evaluación ambiental prevista en la Ley 9/2006, de 28 de abril, sobre evaluación de los efectos de determinados planes y programas en el medio ambiente y en la normativa que la modifiquen o sustituyan. La Ley 42/2007 incorpora en la planificación ambiental o a los Planes de Ordenación de los Recursos Naturales, los corredores ecológicos, otorgando un papel prioritario a las vías pecuarias y las áreas de montaña. Estos corredores ecológicos deben participar en el establecimiento de la red europea y comunitaria de corredores biológicos definidos por la Estrategia Paneuropea de Diversidad Ecológica y Paisajística y por la propia Estrategia Territorial Europea. En particular las Comunidades autónomas podrán utilizar estos corredores ecológicos, o la definición de áreas de montaña, con el fin de mejorar la coherencia ecológica, la funcionalidad y la conectividad de la Red Natura 2000.

El Título II, recoge la Catalogación, conservación y restauración de hábitats y espacios del patrimonio natural. Dedicándose el Capítulo I a la catalogación de hábitats en peligro de desaparición. El Capítulo II establece el régimen especial para la protección de los espacios naturales, partiendo de la definición de la Ley 4/1989, con la incorporación específica de las Áreas Marinas Protegidas, y la creación de la red de áreas marinas protegidas, en línea con las directrices de la Unión Europea, así como la posibilidad de crear espacios naturales protegidos transfronterizos. La ley mantiene la figura, definición y regímenes de protección de los Parques y de las Reservas Naturales de la Ley 4/1989, adaptando la definición de los Paisajes Protegidos al Convenio del paisaje del Consejo de Europa. La declaración y gestión de los espacios naturales protegidos corresponderá, en todo caso, a las Comunidades autónomas en cuyo ámbito territorial se encuentren ubicados. Para estos espacios la Ley 42/2007, mantiene la posibilidad de crear zonas periféricas de protección, la declaración de utilidad pública, a efectos expropiatorios de los bienes y derechos afectados, así como la facultad de la Administración competente para el ejercicio de los derechos de tanteo y retracto. El Capítulo III aborda la Red Ecológica Europea Natura 2000, compuesta por los Lugares de Importancia Comunitaria, las Zonas Especiales de Conservación y las Zonas de Especial Protección para las Aves. Estos espacios tendrán la consideración de espacios protegidos, con la denominación específica de espacios protegidos Red Natura 2000, con el alcance y las limitaciones que las Comunidades autónomas establezcan en su legislación y en los correspondientes instrumentos de planificación. Las Comunidades autónomas definirán estos espacios y darán cuenta de los mismos al Ministerio de Medio Ambiente a efectos de su comunicación a la Comisión Europea, así como fijarán las medidas de conservación necesarias, que implicarán apropiadas medidas reglamentarias, administrativas o contractuales, y asegurar su inclusión en planes o instrumentos adecuados, que respondan a las exigencias ecológicas de los tipos de hábitats naturales y de las especies presentes en tales 
áreas, vigilando el estado de conservación y remitiendo la información que corresponda al Ministerio de Medio Ambiente, que presentará el preceptivo informe cada seis años a la Comisión Europea. La definición de estos espacios se realizará conforme a los criterios fijados en la Directiva 92/43/CEE del Consejo, de 21 de mayo de 1992, relativa a la conservación de los hábitats naturales y de la fauna y flora silvestres, que ha sido objeto de transposición por norma de rango reglamentario. Para asegurar la preservación de los valores que han dado lugar a la definición de estas zonas, se establecen las correspondientes cautelas, de forma que cualquier plan, programa o proyecto que, sin tener relación directa con la gestión de un espacio de la Red Natura 2000, o sin ser necesario para la misma, pueda afectar de forma apreciable a los citados lugares, ya sea individualmente o en combinación con otros planes, programas o proyectos, se someterá a una adecuada evaluación de sus repercusiones en el lugar, de forma que las Comunidades autónomas correspondientes sólo manifestarán su conformidad con dicho plan, programa o proyecto tras haberse asegurado de que no causará perjuicio a la integridad del lugar en cuestión y, si procede, tras haberlo sometido a información pública. En este sentido, se acepta que podrá realizarse el plan, programa o proyecto, pese a causar perjuicio, si existen razones imperiosas de interés público de primer orden que, para cada supuesto concreto, hayan sido declaradas mediante una ley o mediante acuerdo, motivado y público, del Consejo de Ministros o del órgano de Gobierno de la Comunidad autónoma. Por último, se establece que sólo se podrá proponer la descatalogación total o parcial de un espacio incluido en Red Natura 2000 cuando así lo justifiquen los cambios provocados en el mismo por la evolución natural, y previo trámite de información pública. El Capítulo IV aborda las áreas protegidas por instrumentos internacionales de conformidad con, y en cumplimiento de lo dispuesto en los Convenios y acuerdos internacionales correspondientes (humedales de Importancia Internacional, sitios naturales de la Lista del Patrimonio Mundial, áreas marinas protegidas del Atlántico del nordeste, Zonas Especialmente Protegidas de Importancia para el Mediterráneo (ZEPIM), Geoparques, Reservas biogenéticas del Consejo de Europa, etc.) para las que el Ministerio de Medio Ambiente, con la participación de las Comunidades autónomas, elaborará, en el marco del Plan Estratégico Estatal del Patrimonio Natural y la Biodiversidad, unas directrices de conservación, que deberán ser aprobadas por acuerdo de la Conferencia Sectorial de Medio Ambiente, en paralelo con las correspondientes a las de la Red Natura 2000, como marco orientativo para la planificación y gestión de estos espacios.

El Título III de la Ley 42/2007 se centra en la Conservación de la Biodiversidad. El Capítulo I aborda la Conservación in situ de la biodiversidad autóctona silvestre, atendiendo preferentemente a la preservación de sus hábitats y estableciendo regímenes específicos de protección para aquellas especies silvestres cuya situación así lo requiera. Para ello se crea el Listado de Especies en Régimen de Protección Especial con el efecto de que la inclusión de un taxón o población en el mismo conllevará la evaluación periódica de su estado de conservación y la prohibición de afectar negativamente a su situación. En el seno del Listado de Especies en Régimen de Protección Especial, se establece el Catálogo Español de Especies Amenazadas. El Capítulo II incluye la Conservación ex situ, mientras que el Capítulo III, lo hace en la prevención y control de las especies exóticas invasoras, creando el Catálogo Español de Especies Exóticas Invasoras, que fue desarrollado a través de distintas disposiciones. EI Capítulo IV desarrolla la protección de las especies en relación con la caza y la pesca continental.

EI Título IV se centra en la promoción del uso sostenible del patrimonio natural y de la biodiversidad. El Capítulo I aborda las Reservas de la Biosfera Españolas, que constituyen un subconjunto de la Red Mundial de Reservas de la Biosfera, del Programa MaB (Persona y Biosfera) de la UNESCO. El Capítulo II regula el acceso a los recursos genéticos procedentes de taxones silvestres y el reparto de beneficios derivados de su utilización, de acuerdo con lo dispuesto en el Convenio sobre la Diversidad Biológica y sus instrumentos de desarrollo y, en su caso, en el Tratado Internacional sobre Recursos Fitogenéticos para la Alimentación y la Agricultura de la Organización Mundial para la Alimentación y la Agricultura (FAO). El Capítulo III recoge el comercio internacional de especies silvestres, adecuando su desarrollo a los principios de la sostenibilidad $y$, de acuerdo con la legislación internacional, en particular la Convención sobre el comercio internacional de especies amenazadas de fauna y flora silvestres, el Convenio sobre la Diversidad Biológica, el Tratado Internacional sobre Recursos Fitogenéticos para la Alimentación y la Agricultura de la Organización Mundial para la Alimentación y la Agricultura (FAO) y a la normativa comunitaria sobre protección de las especies amenazadas, mediante el control del comercio. Por último, el Capítulo IV se centra en los aspectos aplicables del mismo Convenio sobre la Diversidad Biológica y de la Organización Mundial de Propiedad Intelectual, sobre promoción de los conocimientos tradicionales para la conservación del Patrimonio Natural y la Biodiversidad. El Título $V$ recoge las disposiciones específicas dirigidas al fomento del conocimiento, la conservación y restauración del patrimonio natural y de la biodiversidad. El Título VI recoge las disposiciones generales, tipificación y clasificación de las infracciones y la clasificación y prescripción de las correspondientes sanciones, así como la prevalencia de la responsabilidad penal sobre la administrativa.

En cuanto a la Protección de Espacios, la Ley 42/2007 distribuye estos en tres grupos con características y estatus jurídicos diferenciados. El primero es el representado por los Espacios Naturales Protegidos, que como ya hemos indicado mantienen las para la mayoría de ellos las definiciones ya contempladas en la Ley 4/89, adaptando la definición de Paisaje Protegido al Convenio Europeo del Paisaje, a la vez que se añade una nueva categoría de Espacio Natural Protegido, las Áreas Marinas Protegidas. Parques:1.- Los Parques son áreas naturales, que, en razón a la belleza de sus paisajes, la representatividad de sus ecosistemas o la singularidad de su flora, de su fauna o de su diversidad geológica, incluidas sus formaciones geomorfológicas, poseen unos valores ecológicos, 
estéticos, educativos y científicos cuya conservación merece una atención preferente. 2.- Los Parques Nacionales se regirán por su legislación específica. 3.- En los Parques se podrá limitar el aprovechamiento de los recursos naturales, prohibiéndose en todo caso los incompatibles con las finalidades que hayan justificado su creación. 4.- En los Parques se facilitará la entrada de visitantes con las limitaciones precisas para garantizar la protección de aquéllos. 5.- Se elaborarán los Planes Rectores de Uso y Gestión, cuya aprobación corresponderá al órgano competente de la Comunidad autónoma. Las Administraciones competentes en materia urbanística informarán preceptivamente dichos Planes antes de su aprobación. En estos Planes, que serán periódicamente revisados, se fijarán las normas generales de uso y gestión del Parque. 6.- Los Planes Rectores prevalecerán sobre el planeamiento urbanístico. Cuando sus determinaciones sean incompatibles con las de la normativa urbanística en vigor, ésta se revisará de oficio por los órganos competentes (art. 30). Reservas Naturales: 1.- Las Reservas Naturales son espacios naturales, cuya creación tiene como finalidad la protección de ecosistemas, comunidades o elementos biológicos que, por su rareza, fragilidad, importancia o singularidad merecen una valoración especial. 2.- En las Reservas estará limitada la explotación de recursos, salvo en aquellos casos en que esta explotación sea compatible con la conservación de los valores que se pretenden proteger. Con carácter general estará prohibida la recolección de material biológico o geológico, salvo en aquellos casos que por razones de investigación, conservación o educativas se permita la misma, previa la pertinente autorización administrativa (art. 31). Area Marinas Protegidas: 1.- Las Áreas Marinas Protegidas son espacios naturales designados para la protección de ecosistemas, comunidades o elementos biológicos o geológicos del medio marino, incluidas las áreas intermareal y submareal, que en razón de su rareza, fragilidad, importancia o singularidad, merecen una protección especial. Podrán adoptar esta categoría específica o protegerse mediante cualquier otra figura de protección de áreas prevista en esta Ley, en cuyo caso, su régimen jurídico será el aplicable a estas otras figuras, sin perjuicio de su inclusión en la Red de Áreas Marinas Protegidas. 2.- Para la conservación de las Áreas Marinas Protegidas y de sus valores naturales, se aprobarán planes o instrumentos de gestión que establezcan, al menos, las medidas de conservación necesarias y las limitaciones de explotación de los recursos naturales que procedan, para cada caso y para el conjunto de las áreas incorporables a la Red de Áreas Marinas Protegidas. 3.- Independientemente de la categoría o figura que se utilice para su protección, las limitaciones en la explotación de los recursos pesqueros en aguas exteriores se realizarán conforme a lo establecido en el artículo 18 de la Ley 3/2001, de 26 de marzo, de Pesca Marítima del Estado. 4.- La Conferencia Sectorial, a propuesta de las Comunidades autónomas litorales y de la Administración General del Estado, establecerá los criterios mínimos comunes de gestión aplicables a las Áreas Marinas incluidas en la Red (art. 32). Monumentos Naturales: 1.- Los Monumentos Naturales son espacios o elementos de la naturaleza constituidos básicamente por formaciones de notoria singularidad, rareza o belleza, que merecen ser objeto de una protección especial. 2.- Se considerarán también Monumentos Naturales los árboles singulares y monumentales, las formaciones geológicas, los yacimientos paleontológicos y mineralógicos, los estratotipos y demás elementos de la gea que reúnan un interés especial por la singularidad o importancia de sus valores científicos, culturales o paisajísticos. 3.- En los Monumentos con carácter general estará prohibida la explotación de recursos, salvo en aquellos casos que por razones de investigación o conservación se permita la misma, previa la pertinente autorización administrativa (art. 33). Paisajes Protegidos: 1. Paisajes Protegidos son partes del territorio que las Administraciones competentes, a través del planeamiento aplicable, por sus valores naturales, estéticos y culturales, y de acuerdo con el Convenio del paisaje del Consejo de Europa, consideren merecedores de una protección especial. 2.- Los objetivos principales de la gestión de los Paisajes Protegidos son los siguientes: a) La conservación de los valores singulares que los caracterizan. b) La preservación de la interacción armoniosa entre la naturaleza y la cultura en una zona determinada. 3.- En los Paisajes Protegidos se procurará el mantenimiento de las prácticas de carácter tradicional que contribuyan a la preservación de sus valores y recursos naturales (art. 34).

La nueva normativa estatal supone una mejora sustancial en el marco jurídico y de acción en la conservación de la naturaleza, aunque persisten una serie de deficiencias. Una de ellas es la falta de criterios claro para la conservación y gestión de la biodiversidad y de los componentes del Patrimonio Natural fuera del ámbito de los espacios naturales protegidos y de la estricta protección que se establece para distintos componentes (hábitats, especies protegidas). La diferenciación competencial Administración General del Estado / Comunidades Autónomas conduce a un tratamiento inadecuado de la biodiversidad del medio marino, que para muchos componentes no entiende de líneas de base y de su pertenencia aguas interiores y exteriores, y cuya gestión no puede hacerse desde un visión meramente centralista. La resolución de los problemas provocados por la contaminación, el tráfico de busques., la invasión de especies exóticas, la sobreexplotación de recursos pesqueros y marisqueros, así como el vinculado del creciente uso público y deportivo exige un tratamiento global, como también resulta necesario redefinir la estrategia de delimitación de las áreas marinas protegidas y para ello reforzar tanto a nivel de la Directiva Hábitat y Aves, como de las normativas estatales y autonómicas el estatus de protección sobre los hábitats y las especies del medio marino. Una situación similar ocurre con la geodiversidad, donde la protección de esta ha sido tradicionalmente relegada frente a la de la biodiversidad, y donde espacios de gran significación geológica, geomorfológica, paleontológica presentes en el territorios español carecen de protección jurídica.

La solución adoptada para los espacios de la Red Natura 2000 para la más adecuada dada la diversidad de opciones que por falta de concreción en la normativa estatal, han ido estableciendo las normativas de las distintas Comunidades Autónomas, que ahora se les otorga un tratamiento 
homogéneo. Este tratamiento exige equipar los Espacios Naturales Protegidos y Espacios Protegidos de la Red Natura 2000, en las diferentes normativas sectoriales, proceso que se ha resuelto en distintas que inciden sobre el medio ambiente, como ya se ha resuelto en la relativa a impacto ambiental, pero todavía no ha sido convenientemente adaptada en otros normas como en el Código Penal (Ley Orgánica 10/1995), donde en relación a los delitos contra los recursos naturales y el medio ambiente, solamente se contemplan los Espacios Naturales Protegidos. Por el contrario, el tratamiento de las áreas protegidas por instrumentos internacionales se reduce a la mayoría de las categorías a su enunciado. Esta situación se hace evidente en el caso de los Geoparques tanto en relación con los objetivos básicos que debería cubrir una Area Protegida (objetivos y directrices de conservación, medidas de gestión, régimen de actividades permitidas, autorizables y prohibidas, procesos de evaluación de impacto ambiental, responsabilidad política y administrativa de sus promotores, etc), así como la necesidad de harmonizar sus actuaciones con las establecidas en otros espacios. De no resolverse esta situación los Geoparques corren el riesgo de convertirse en una marca turística comercial devaluada que se aleja de la consideración de un área protegida del siglo XXI.

La Ley 42/2007, contempla tres grandes catálogos relativos a los componentes de la biodiversidad integrados en el Inventario Español del Patrimonio Natural y la Biodiversidad (Real Decreto 556/2011). El primero se corresponde con el Listado de Especies en Régimen de Protección Especial que incluye el Catálogo Español de Especies Amenazadas CEEA (Real Decreto 139/2011), el cual reformula al antiguo Catalogo Nacional de Especies Amenazadas CNEA (Real Decreto 439/1990). Tanto el listado, como el CEEA han tenido a lo largo de estos últimos años distintas modificaciones, constituyéndose en una elemento básico para asegurar la conservación de la biodiversidad en el Estado. Catálogo de hábitats en peligro de desaparición. Tras la publicación se realizó una catalogación de los tipos de hábitats a partir de la clasificación EUNIS desarrollada por la Agencia Europea de Medio Ambiente. El resultado de esta catalogación es deficiente, reduciéndose a una mera lista, en la que se han excluido tipos de hábitats que de acuerdo con la información científica-técnica publicada están presentes en las distintas regiones biogeográficas del Estado Español (Resolución 22/03/2013, Resolución 17/02/2017). A la mala catalogación se une una falta de medidas para garantizar la preservación a corto o largo plazo de estos tipos de hábitats. El tercer catálogo es el: Catálogo Español de Especies Exóticas Invasoras, formalmente está muy mejor configurado e imbricado en la propia normativa, que el Catálogo de hábitats en peligro de desaparición, sin embargo los cambios realizados en el mismo (Real Decreto 1628/2011, Real Decreto 630/2013) a tenor de las veleidades políticas han restado credibilidad y efectividad al mismo, dada la miopía o interés económico por no otorgar la condiciones legal de especies exóticas invasoras aquellas que de acuerdo con las evidencias científico-técnicas se muestran como tales.
Llama la atención que siendo España el tercer país del mundo que más turistas recibe al año, los efectos negativos de este sobre la biodiversidad y el patrimonio no hayan sido tratados en la Ley 42/2007. En consecuencia, la Ley también carece de medidas adecuadas para evitar que dichas actuaciones, así como las infraestructuras y construcciones vinculadas con el mismo sigan a generar un modelo de sobreexplotación, contaminación y destrucción como se aprecia tanto en las áreas litorales, como por desgracia se extiende a las áreas de montaña y los elementos de mayor singularidad del territorio.

Otro aspecto criticable de la Ley 42/2007 es la perpetuación de un modelo político-burocratizado en la toma de decisiones sobre el medio ambiente, que actúa de forma habitual al margen del conocimiento científico-técnico, cuando no en contra de las evidencias derivadas de este. A ello se une la necesidad de mejorar los modelos de consulta, especialmente a centros y grupos de investigación independientes, así como los de participación ciudadana, buscando en estos la máxima representación de sectores y organizaciones.

El análisis de las Declaraciones de Impacto Ambiental publicadas en el BOE y el DOG, de grandes obras o grandes obras o infraestructuras en la que se prevé una incidencia que fueron aprobadas en los últimos 20 años (1999-2019), se aprecia como en estos procesos se aprecia una baja respuesta entre las administraciones consultadas, faltando muchas veces el informe de los organismos autonómicos responsables en la conservación de la naturaleza. Pero lo más grave es que se suelen invitar al mismo proceso a entidades ambientales que no contestan porque llevan más de 10 años sin ninguna actividad. O bien se excluyen de la consulta a las actividades ambientales locales y se envía la misma a los grandes corporaciones ambientales del estado. En ningún caso se incluyen informes emitidos por entidades independientes, no vinculadas estructuralmente con las propias administraciones que impulsan el proyecto. Muchos de los problemas ambientales que se generan en Galicia gravitan a nuestro entender en la ejecución de un inadecuado procesos de evaluación ambiental.

Factores de amenaza sobre la biodiversidad y situación de las áreas protegidas de Galicia

El Plan Director de la Red Natura 2000 (Decreto 37/2014) y los documentos técnicos del mismo (Ramil-Rego \& Crecente Maseda, 2012; Ramil-Rego et al. 2005, 2008, 2012), muestran una completa radiografía de la biodiversidad y el patrimonio natural de Galicia. Según la a información del Plan Director (Ramil-Rego \% Crecente Maseda, 2012), Galicia tiene una superficie de 3.354.355,5 ha, con una superficie terrestre de $2.957 .509,0$ ha y una superficie marina (0-100 $\mathrm{m}$ de profundidad) de 396.846,5 ha, con una línea de costa de más de $1.676 \mathrm{~km}$ de perímetro. La Red Natura 2000 está configurada por 75 espacios, 59 Zonas de Especial Conservación (ZEC), y 16 Zonas de Protección para las Aves (ZEPA), la mayor parte de la superficie de las ZEPA está integrada en una ZEC. Y 
de nuevo la mayor parte de los Parques, Monumentos Naturales, Humedales Protegidos y Paisajes Protegidos forman también parte de la Red Natura 2000. La superficie total de Red Natura 2000 es de 389.565,9 ha (354.575,6 ha $12,0 \%$ terrestres y $34.990,3$ ha $8,8 \%$ marinas). Las ZEC representan $374.434,8$ ha y las ZEPA $101.134,9$ ha. La superficie total de Espacios Naturales Protegidos es de $399.373,3$ ha de las que $360.600,8$ ha son terrestres $(12,2 \%)$ y $38.951,9$ ha $(9,7 \%)$ son marinas (Ramil-Rego \& Crecente Maseda, 2012; Ramil-Rego et al. 2005, 2008, 2012 (Figura 2).

En Galicia están presentes 72 tipos de interés comunitario (33\%), de los cuales 18 son considerados como prioritarios (25\%). Todos los tipos de hábitats naturales del Anexo I da DC 92/43/CEE, muestran una presencia significativa dentro de los ZEC y ZEPA. Algunos de los cuales incluyen en Galicia su mayor representación en el conjunto de la Región Biogeográfica Atlántica. En cuanto a las especies, el territorio gallego alberga más de 10.000 especies silvestres (hongos, flora, fauna), de las cuales solamente 531 tienen un estatus jurídico de protección derivado de la Directiva Hábitats (6 especies prioritarias, 61 especies de interés comunitario, 96 especies en el Anexo IV y 29 especies en el Anexo IV), la Directiva Aves (81 especies en el Anexo I y más de 60 especies en el resto de los anexos), la normativa estatal (16 especies En Peligro, 33 especies Vulnerables y 296 especies en el Listado de Especies Silvestres en Régimen de Protección Especial) y autonómica (74 especies En Peligro y 126 Vulnerables), con muchas especies que aparecen incluidas en los distintos ámbitos (Ramil-Rego \& Crecente Maseda, 2012; Ramil-Rego et al. 2005, 2008a,b, 2012).

La superficie total de Espacios Naturales Protegidos de Galicia se muestra sin embargo muy reducida si se compara con la de otras Comunidades Autónomas. Los valores porcentuales de áreas marinas protegidas y continentales no alcanzan los valores mínimos planteados en el Convenio de Diversidad Biológica en su Plan Estratégico para la Diversidad Biológica 2011-2020 (CBD, 2010). A esta situación se suma un estado deficiente de conservación de

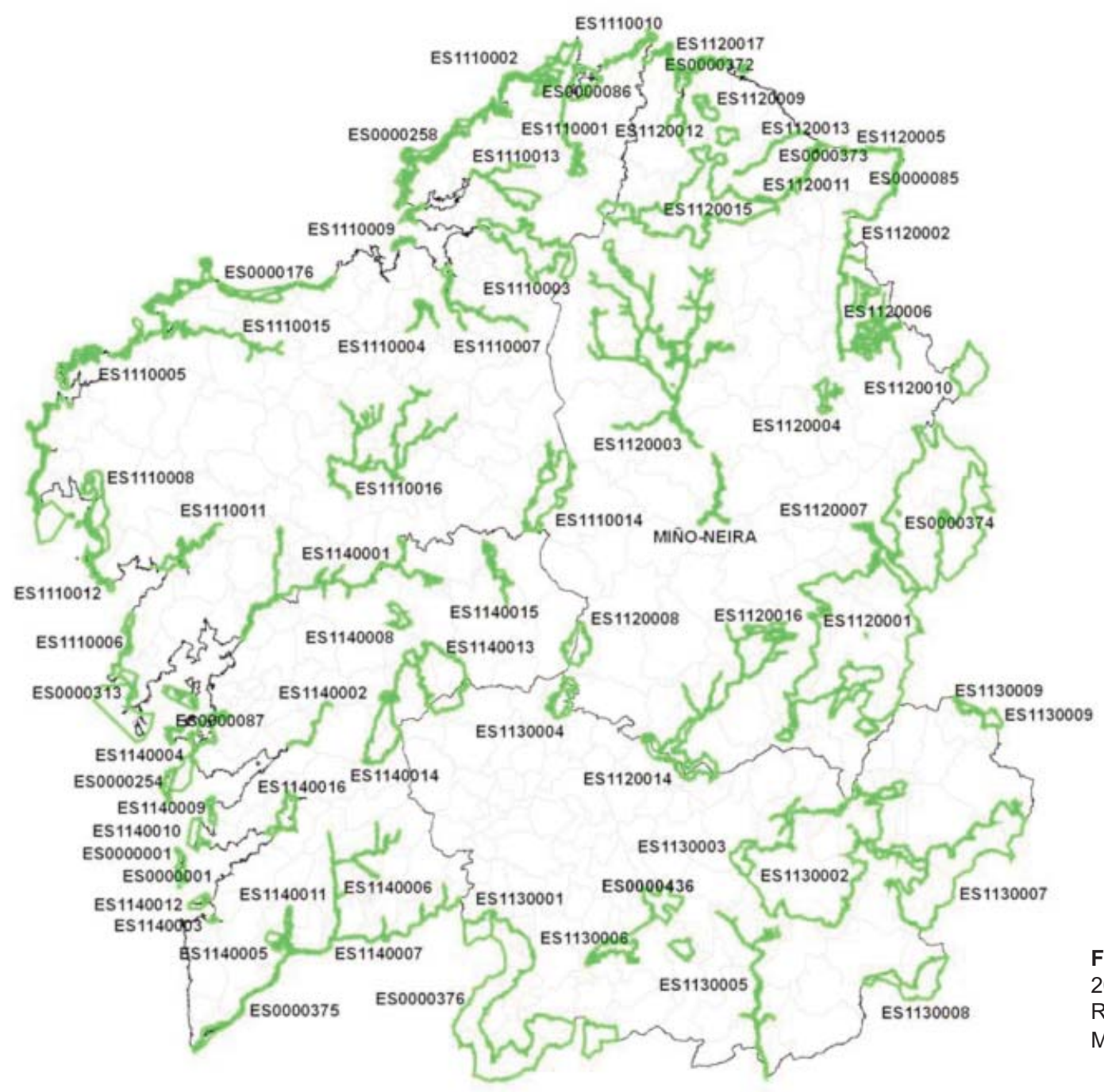

Figura 2. Rede Natura 2000 de Galicia (RamilRego \& Crecente Maseda, 2012). 
los hábitats y de las especies de interés comunitario como se muestran en los informes generados por la Agencia Europea de Medio Ambiente (EEA) en relación con el tercer periodo de evaluación de la Red Natura 2000 (2013-2018), en el que la totalidad de los tipos de hábitats de interés comunitario presentes en Galicia muestran un estado de conservación desfavorable, situación que igualmente se aprecia para la mayoría de las especies de flora y fauna. La información oficial de la Comisión Europea contrasta con la propaganda de los medios oficiales de comunicación y promoción turística de Galicia que venden el territorio gallego como un paraíso terrenal, obviando cualquier referencia a la crítica situación en que se encuentra la biodiversidad gallega, mientras que se fomentan actuaciones que en muchos afectan a la integridad de los espacios naturales y al estado de conservación de sus componentes.

Entre los factores adversos que amenazan la la Biodiversidad y el Patrimonio Natural de Galicia, así como la propia integridad de los espacios naturales protegidos, consideramos los siguiente:

A.1.- Incendios forestales. Los incendios forestales son un elemento recurrente en el paisaje gallego tanto en periodos históricos, como recientes (Casares Long, 2003; DíazFierros \& Baamonde, 2006; Varela Díaz, 2017; Díaz-Fierros, 2018, 2019). En el periodo de 23 años comprendido entre 1976-1999, la superficie contabilizada de incendios en Galicia superaba las 1.128.769 ha, que representa el $38,16 \%$ de la superficie continental de Galicia, mientras que en los 20 años siguientes (2000-2018), la superficie quemada se redujo a 494.226 ha $(16,71 \%)$, aunque en este segundo periodo se encuentran años en los que contabilizan menos de 10.000 ha quemadas, y otros en los que se supera las 50.000 ha, llegándose alcanzar el valor máximo en el año 2006 con más de 90.000 ha. Una parte significativa de la superficie quemada desde el año 2000 se corresponde a espacios protegidos, habiendo estos afectado al Parque Natura das Fragas do Eume, Parque Natura de Corrubedo, Parque Natural da Baixa Limia Serra do Xurés. Así como a numerosos espacios de la Red Natura 2000 (ZEC Ortegal, ZEC Costa da Morte, ZEC Os Ancares - O Courel, ZEC Macizo Central, etc). La casi totalidad de los incendios están vinculados a un acción directa o indirecta, pero a pesar de ello el número de personas detenidas y condenadas como incendiarios es muy insignificante. Es difícil dar una explicación única y simple a esta anómala situación, pero no se puede dudar que esta implícitamente vinculada con los usos actuales del territorio donde las grandes superficies forestales de cultivo intensivo dominadas por eucaliptos y pinos constituyen la matriz del paisaje de grandes áreas de Galicia que fagocita los elementos de un urbanismo caótico donde los rural mal cuidado, se mezcla con un neorural o a formas transicionales de tejidos pseudourbanos. El crecimiento de las plantaciones y lo construido se realiza a costa de reducirse las áreas con vegetación natural y especialmente de aquella que puede mitigar el avance del fuego, mientras que las infraestructuras que discurren entre este paisaje de eucaliptos y pinos es el heredado de la época de los carromatos tirados por animales. Solo falta una condiciones climáticas propicias para secar la vegetación y la presencia de un delincuente para que se produzca una catástrofe como aconteció en el fatídico fin de semana del 14-15 de octubre de 2017, donde el fuego diezmo el pequeño valle de Chandebrito (Nigrán), quemando en pocas horas más de 600 ha y calcinando a dos personas que circulaban en coche por una tortuosa y estrecha carretera. La ola incendiara del 14-15 de octubre dejo en Galicia 264 fuegos, con una superficie quemada de 49.171 ha (53\% arbolado, $47 \%$ matorral). Por provincias, junto con 4 personas muertas y 20 casas destruidas. El $23 \%$ de la superficie quemada formaba parte de la Red Natura 2000. A pesar de la importante superficie de afección de los incendios forestales gallegos, su severidad y recurrencia resulta difícil obtener datos concretos sobre los efectos a corto o medio plazo sobre la biodiversidad y concretamente sobre los Espacios Naturales Protegidos, así como una valoración de la eficacia de las medidas de restauración llevadas a cabo. Las únicas referencias publicadas abordan aspectos químicos del suelo o relativos a la estructura forestal de la masa, una información que aunque interesante es poco relevante para caracterizar los efectos sobre el medio ambiente y concretamente sobre la biodiversidad.

A.2.- Intensificación de las producciones primarias. LoS ayudas europeas vinculadas a fondos FEDER, FEADE, FSE han sido empleadas para intensificar los modelos de producción agrícola, ganadera, forestal asi como marisquera y de acuicultura en la Red Natura de Galicia al margen de cualquier criterio de sostenibilidad, sorteando hábilmente los impedimento y restricciones que las normativas europeas contemplan. De este modo directa o indirectamente se han apoyado y autorizado acciones de plantaciones forestal sobre hábitats prioritarios de carácter herbáceo o arbustivo, que conllevaron su alteración o generalmente su completa destrucción. Del modelo ganadero extensivo se pasó a otras más intensivo, y gracias a la compra de nueva maquinaria se procedió a "desbrozar" grandes superficies ocupadas por turberas, matorrales húmedos y matorrales secos, principalmente en los espacios montañosos. La intensificación se muestra igualmente en las áreas agrícolas, el clásico bocage Atlántico que dominaba el paisaje de la mayor parte de Galicia a finales de la década de 1970 (Bouhier, 1979), sufrió en los últimos 40 años una progresiva reducción y sustitución, vinculada con la ejecución de proyectos de concentración parcelaria, y de mejora agraria (Bacariza Cortiñas, 1994; MEL, 1993, 1994; Vales Vázquez, 1994), permaneciendo en la actualidad confinado a pequeños retazos de las comarcas del interior de Galicia, mientras han crecido las superficie agrarias-ganaderas intensivas y se generalizó la eucaliptización del territorio. Un situación similar se observa en el medio marino con la extensión de los polígonos marisqueros y las plantas de acuicultura (Eirexas Santamarina, 2016; Rodriguez, 2011), planteados sin una mínima evaluación de sus repercusiones sobre el medio ambiente.

La eucaliptización del territorio gallego (Codero-Rivera, 2019; Díaz-Fierros, 2019; González Prieto, 2019) se muestra con dureza en el Parque Natural das Fragas do Eume y de su entorno. Desde la declaración de este 
espacio (Decreto 218/1997), el gobierno autonómico ha sido incapaz de poner en marcha políticas que garantizasen la conservación del Bosque Atlántico, que incluyes áreas de gran relevancia ambiental por la presencia de comunidades de relictos paleozoicos (Culcita macrocarpa, Woodwardia radicans). En el año 2012 un desbastador incendio afecto a una parte importante de este espacio al propagarse a través de las superficies de eucaliptos que dominan en su área periférica. Aunque una parte sustancial de bosque atlántico fue afectada por el fuego (400 ha), el Parque Natural sigue estando rodeado de eucaliptales y estos también se han extendido en sus áreas centrales. En el Parque Natural Baixa Limia - Serra do Xurés (Decreto 401/2009), la forestación intensiva se realiza con especies de pinos (Pinus pinaster, Pinus sylvestris) a partir de materiales genéticos exóticos y a costa de reducir la superficie de hábitats de interés comunitario dentro del Parque.

A.3.-Usos constructivos. Entre los factores más adversos sobre la integridad de los espacios naturales de Galicia y el estado de conservación de sus hábitats y especies silvestres, debemos destacar sin dudas el desastroso desarrollo urbanismo que caracteriza muchas áreas urbanas y rurales de Galicia. Las principales ciudades gallegas, especialmente las del litoral Atlántico (Coruña, Santiago, Pontevedra, Vigo), han experimentado un gran crecimiento anexando de forma caótica a las viejas áreas urbanas nuevos polígonos de viviendas, comerciales e industriales, sin respetar o infravalorar los elementos del Patrimonio Natural y Cultural. El auge constructivo con menor intensidad, pero igualmente con efectos adversos sobre el medio ambiente se muestra igualmente en las pequeñas villas y en general en los espacios rurales, especialmente del área litoral, donde afloran sin control todo tipo de viviendas, generalmente de segunda residencia, junto con establecimientos industriales y comerciales (Greenpeace, 2001, 2002, 2003, 2004, 2005, 2006, 2007, 2008, 2009, 2010, 2011, 2012, 2013, 2017, 2018, 2019). El caos urbanístico se manifiesta con dureza en las Rías de Arousa, Pontevedra y Vigo, aniquilando en su avanza los pocos elementos de interés ambiental. Pero también ser percibe en la costa de Miño y en la Mariña de Lugo. En estas dos últimas localidades, la última crisis económica global supuso la ruina de muchas iniciativas constructivas, dejando una paisaje desolador de viviendas inacabadas (López Vispo, 2018; Abel Vilela, A. \& Pallin Seo, 2010; Eirexas Santamaría, 2010; López Vispo, 2010a,b,c; Pallín Seco, 2010).

La expansión constructiva en Galicia se realizó de forma desacoplada con las medidas para reducir los efectos negativos de estas (pérdida de superficies de hábitats, afecciones sobre especies protegidas, contaminación de aguas, contaminación lumínica). En este sentido la capital de Galicia, Santiago de Compostela, carece en la actualidad de un adecuado tratamiento de sus aguas residuales, situación que hasta hace pocos años compartía también con la ciudad de Ferrol. A la ausencia de depuración, habría que unir el escaso número de plantas con tratamiento terciario y el funcionamiento anómalo que muestran muchas de ellas. Los problemas de contaminación química y bacteriológica se han incrementado en Galicia dada la falta de medidas de depuración y el incremento de las superficie urbanas e industriales, así como con el incremento de la carga ganadera, o la existencia de graves accidentes, como el hundimiento del petrolero Prestige (González Laxe, 2003; Prada \& Vázquez, 2004; Figueras et al. 2005; Urgorri, 2010). Resulta extraño que no se hayan priorizado las actuaciones de construcción de plantas depuradoras en un país que muestra una gran dependencia de la comercialización de productos obtenidos en el campo, la pesca y el marisqueo, así como de las actividades turísticas, mientras que se han empleado fondos europeos para la construcción de paseos marítimos y fluviales.

Las actuaciones urbanísticas no han respetado ni los espacios naturales, ni los hábitats protegidos. Un simple análisis diacrónico de las ortoimágenes de alta resolución del Vuelo de Costas (1989-1991), previo a la declaración de la Red Natura 2000 de Galicia, y las referidas al PNOA (2007-2016) permite comprobar la construcción de numerosas edificaciones, generalmente viviendas de segunda residencia, emplazadas sobre áreas que previamente establan cubiertas por sistemas dunares, humedales, matorrales costeros o bosques dentro de los espacios protegidos de la Red Natura 2000, estas actuaciones se aprecian especialmente en el litoral de $A$ Coruña (ZEC Costa Ártabra, ZEC Costa da Morte, ZEC Complexo Húmido de Corrubedo). En otras áreas, aunque la construcción no han afectado directamente a la superficie declarada como espacio natural, su desarrollo a tenido un efecto igualmente negativo al actuar como barreras permanentes alterando los flujos naturales de las especies, o alterando el funcionamiento y la calidad de las aguas de ríos y humedales que finalmente drenan a los propios espacios naturales. Este hecho resulta muy preocupante dado que la casi totalidad de los espacios litorales de Galicia han sido delimitados sin considerar los procesos dinámicos que caracterizan a los ecosistemas litorales, y especialmente las relacionadas con la subida del nivel del mar, y tampoco se han contemplado áreas buffer lo suficientemente robustas entorno a las zonas de mayor valor y fragilidad.

A.4.- Parques Eólicos. Un tercer elemento adverso son los Parques Eólicos. Nadie duda de que la energía eólica es un fuente de energía sostenible, y que resulta menos contaminante frente a las instalaciones industriales alimentadas por combustibles fósiles o por combustibles no fósiles. Pero no se puede dudar de que las actuales instalaciones eólicas tienen un alto impacto a nivel del paisaje y las infraestructuras necesarias para su montaje y explotación pueden generar graves problema ambientales cuando se construyen sobre las áreas cimeras de las montañas. Estas cautelas no se tuvieron en cuenta en Galicia, donde la casi totalidad de los parques eólicos se han emplazado en cumbres o en la partes más altas de las ladera, construyendo para ello todo tipo de viales, pistas, conducciones subterráneas, conducciones aéreas, subestaciones eléctrica, etc., a partir de proyecto donde la información ambiental no resultaba rigurosa, llevándose a cabo además procedimientos de evaluación ambiental sin cumplir los mínimos criterios de objetividad e imparcialidad (Regeuiro Ferreira, 2011). 
Una anómala situación que ha provocado la construcción de numerosos parques eólicos sobre hábitats prioritarios, concretamente turberas de cobertura (Blanket Bog) y brezales húmedos Atlánticos, estos últimos de gran singularidad en el contexto de la biodiversidad europea. Aunque el Plan Directo de la Red Natura 2000 (DECRETO $37 / 2014$ ), no permite la construcción de nuevos parques eólicos en los espacios protegidos, en el momento de redactar este artículo hemos podido constata el inicio de la construcción de un Parque Eólico sobre la ZEC Os Ancares - O Courel, en la designada como Serra do Oribio (Lugo) que supuestamente había sido autorizado con anterioridad a la aprobación del Plan. De cualquier modo, la tipología constructiva empleada resulta completamente lesiva para un área de montaña, y más aún para un espacio que considerado como un espacio natural.

La situación que se ha generado en Galicia con la instalación de Parque Eólicos en espacios naturales y los daños que estos en su fase constructiva han provocado sobre la biodiversidad y el Patrimonio Natural, es un elocuente ejemplo de mal gobierno, sustentado en procedimientos construidos de forma deficiente (AlvarezCampana et al. 2004) y por la elaboración de informes y estudios promovidos por las empresas (Macías et al. 1998; 1999a,b; Macías \& Calvo, 1999; Macías \& Nieto, 2002; García Arrese et al. 2003a,b; García Arrese, 2005; Tapia et al. 2005) que fueron aceptados por la administración sin contrastarlos con informes independientes, a pesar que se muestran muy deficientes en relación con los criterios que deberían ser considerados en el proceso de evaluación ambiental y fuertemente sesgados a los intereses de los promotores.

A.5.- Minería. De nuevo nos encontramos aquí con una moneda de dos caras totalmente distintas. Por un lado, algunas explotaciones mineras a cielo abierto como las desarrolladas en Meirama y As Pontes, ha llevado a cabo distintas actuaciones de restauración durante las fases de explotación y tras finalizar estas han recreado los huecos mineros generando grandes lagos. Las actuaciones en ambos casos deberían reforzar el uso y la gestión de estos nuevos humedales artificiales, priorizando la gestión del agua y de la biodiversidad frente a actuaciones de carácter lúdicas o deportivas. De cualquier modo, estas actuaciones son totalmente diferente a las que se muestran en otras áreas de Galicia, especialmente en la comarca de Valdeorras (Rodríguez González, 1992), donde la explotación de pizarra al aire libre ha destrozado completamente el paisaje y los ecosistemas. A la destructiva minería de las pizarras se une ahora varios intentos de obtener minerales con formas de explotación que conllevan un potencial impacto para la biodiversidad y la salud humana (Casares Long, 2003; Martín Palmero et al. 2004; Louzao \& Eirexas, 2018; Rodríguez, 2017; González Prieto, 2013; Gutiérrez, 2011). A menor escala encontramos explotaciones a cielo abierto que están alterando de forma significativa la calidad de los espacios naturales. Entre ellas destaca la ZEC Serra do Xistral donde se mantiene una explosión de turba sobre un área de Blanket Bog que se ve progresivamente reducida. También resulta sorprende la existencia de una cantera de piedra en el borde del Parque
Natural de Corrubedo, ubicándose la planta de machado de los materiales de esta dentro del Parque. Ambas actuaciones muestran el escaso interés de la administración autonómica en la defensa del medio ambiente.

A.7.- Industrias. La diseminación del hábitat que caracteriza al urbanismo gallego también se observa a nivel industrial. La mayoría de los polígonos industriales de las pequeñas y medianas villas son meros polígonos comerciales, talleres y servicios, mientras que las plantas industriales se ubican fuera de estos, lo que dificulta un diseño racional de las medidas de monitoreo y tratamiento de las sustancias contaminantes. Solamente en las grandes ciudades encontramos grandes polígonos industriales, incluyendo empresas que no deberían estar enclavadas cerca de entornos urbanos. El análisis de estas actividades y sus efectos ambientales ha sido tratado por distintos trabajos (Romaní Barrientos \& Chantada Acosta, 1996; Díaz-Fierros, 1996; Bermejo Barrera, 2002; Casares Long, 2003; 2005; Martín Palmero et al. 2004; Díez Ramos \& Ramos Medrano, 2014; Díaz-Fierros, 2019) y su análisis supera el objeto de este trabajo.

A8.- Paseos marinos y fluviales. La costa gallega y en gran medida los principales tramos fluviales que discurren por las zonas urbanos y periurbanos se encuentran completamente artificializados con la finalidad de potenciar un uso público masivo. Para ello se han construido viales para uso exclusivo de peatones, con calzadas de 3-4 m de ancho, que se han diseñado sin una adecuada evaluación de los previsibles impactos que las obras y la puesta en marcha de estos podría tener sobre la biodiversidad el Patrimonio Natural y Cultural, más aún cuando estos viales se han construido al margen de las tipologías y materiales tradicionales. Así la superficie de la calzada excepcionalmente aparece recubierta por tierra, empleando por el contrario asfalto, hormigón, resinas, empedrados, enlosados, etc. En algunas actuaciones se utilizan pasarelas de madera, cuyo diseño se plantea más desde una perspectiva estética o para facilitar el tránsito de las personas, obviando de nuevo sus posibles afecciones ambientales. A mayores paralelamente a estos viales peatonales se crean otros destinados a bicicletas y a vehículos. $Y$ finalmente se dotan a los paseos con todo un conjunto de elementos secundarios (aparcamientos de vehículos, caravanas, autobuses, servicios, plazoletas, miradores, zonas de juego, jardines, cabañas, edificios para la restauración y venta de objetos, etc).

A la alteración física y permanente de los paseos se une la falta de criterios ambientales en su diseño, así como de criterios de planificación del uso público, que afectan de forma negativamente tanto al estado de conservación de los hábitats y de las especies de flora y fauna silvestre, como a la seguridad de las personas que los emplean. $Y$ también resulta muy desalentador observar como la vegetación de las áreas entorno a los paseos se encuentran frecuentemente vegetadas por especies alóctonas, o bien se practican desbroces periódicos sobre los hábitats naturales de carácter prioritario (Ramsar Ria do Eo, Ramsar Ortigueira-Mera, Ramsar Lagoa da Frouxeira, Ramsar Complexo Húmido de Corrubedo, Ramsar Umia - O Grove), 
mientras que no existe ningun control sobre las especies exóticas invasoras.

Aunque podemos encontrar paseos fluviales y marinos en toda Europa, es difícil encontrar territorios que se equiparen a Galicia en número y longitud construida, pero también es difícil encontrar fuera de Galicia paseos fluviales o marinos que se han construido a costa de generar un importante impacte. Es difícil conseguir una cifra aproximada de la longitud y superficie que representan los paseos, así como su coste económico que se ha realizado mayoritariamente a través de fondos europeos. Sin embargo, a través del BOE podemos obtener datos parciales sobre la licitación de determinados paseos, en los que habitualmente se establece un coste de $1.000 .000 € / \mathrm{km}$, siempre y cuando no se incluyan viales para vehículos y un gran número de elementos secundarios. A través del BOE se puede igualmente rastrear los elevados costes de mantenimiento de estas infraestructuras provocados por la alteración que generan lo temporales y las inundaciones, así como al tener que subsanar las alteraciones generadas por temporales e inundaciones, así como por la propia degradación de los materiales. El coste global de estas obras no debe ser un cifra modesta, inversión pública que debió ser aplicada para cubrir otras necesidades como la de mejorar la deficiente depuración de la aguas urbanas y rurales.

A.9.- Introducción y expansión de especies exóticas invasoras: Uno de los elementos que marcan esta alarmante situación es la abundancia y extensión de especies exóticas de flora y fauna. En la mayoría de los casos se trata de exóticas empleadas desde inicios del siglo XX como plantas ornamentales (Cortaderia selloana, Carpobrotus edulis, Oxalis pes-caprae, Tradescantia fluminensisetc, Zantedeschia aethiopica, etc), plantas de uso forestal (Acacia spp. Eucalyptus spp., Pawlonia ssp, Populus spp, Robinia Pinus ssp.) ligadas a los sistemas rurales (Arundo donax, Coleostephus myconis, Conyza spp.), explotaciones de animales (Neovison vison) o introducidas de forma negligente o accidental (Azolla spp, Procambarus clarkii, Sus scrofa subsp domestica "vietnamita", Tachemys scripta subsp. elegans, Vespa velutina). Un reciente análisis de estas especies sobre la biodiversidad gallega es el trabajo coordinado por RamilRego \& Vales (2019) en el que se tratan los principales grupos de especies exóticas y su problemática ambiental. Pese a esta grave situación Galicia carece de un catálogo oficial de especies exóticas invasoras y de una estrategia efectiva para su control, mitigación y erradicación.

A.10.- Descontrol de las actividades de uso Público: El modelo turístico planteado para Galicia (Ugarte et al. 2007) es una adaptación del modelo de sol y playa mediterráneo, sin eliminar o mitigar ninguno de los efectos adversos que caracterizan a este tanto desde un punto de vista ambiental. Los efectos de masificación alcanzan cotas aberrantes en los espacios naturales y concretamente en el Monumento Natural da Praia das Catedraís, donde a pesar de las restricciones de aforo (Crecente Maseda et al. 2016), la visita a este singular espacio litoral resulta angustioso, con concentraciones de personas que recuerdan las entradas de metro de una gran ciudad. En la mayoría de los espacios naturales no hay información adecuada para el visitante, a pesar de una excesiva proliferación de cartelería en la que cualquier medida de gestión o regulación se camufla en unos pequeños pictogramas. El servicio de vigilancia es reducido, poco operativo y sin un refuerzo notable en los días previsible más afluencia. La débil estructura de gestión del uso público es generalizada en todos los espacios naturales de Galicia, salvo en el Parque Nacional das Illas Atlánticas, donde el control del visitantes se muestra más adecuado y profesional, homologable con otros espacios europeos. Mientras que los responsables autonómicos del Medio Ambiente son incapaces de gestionar el uso público, otro unidad administrativa, la agencia de turismo, Turgalicia, se dedica a focalizar el uso turístico de los lugares más sensibles y que menos medidas poseen para preservar los valores ambientales (Turgalicia, 2001, 2004; Ugarte Otero, 2007; López Bedoya, 2008; Turgalicia, 2008, 2010, 2013, 2016, 2017).

La gestión racional del uso público es una tarea pendiente en la mayoría de las áreas protegidas de Galicia. Solamente en dos existen una limitación por capacidad de carga. En el Parque Nacional Marítimo Terrestre (Decreto 177/2018), con una superficie terrestre de 1.194 ha, con un máximo de 4.000 personas/día (0,2985 ha/persona). Mientras que en el Monumento Natural da Praia das Catedrais (Decreto $80 / 2015)$, con una superficie terrestre de 8,94 ha, se ha fijado un aforo de 4.812 personas/días $(0,1653 \mathrm{ha} /$ persona) que se concentran en la zona de playa $(50.000 \mathrm{~m} 2)$, lo que supone que se autoriza un aforo de 10 personas por cada $\mathrm{m} 2$ de playa, un valor difícilmente asumible para un espacio natural, y menos aún para un Monumento Natural. En los Parques Naturales, hasta el 2013, existían medidas concretas de vigilancia y control de accesos, así como relativas al uso de determinadas áreas con la finalidad de asegurar la conservación de los componentes de la Biodiversidad y del Patrimonio Natural. Entre las medidas cabe resaltar las efectuadas en el Parque Natural para impedir el deterioro de la Duna Móvil, el elemento más significativo de este espacio, por el pisoteo y el uso lúdico de los visitantes. También existían controles de acceso, especialmente de vehículos en el Parque Natural das Fragas do Inverno.

El cambio de criterio político efectuado a partir del 2013 en la gestión de los Parques Naturales supuso la relajación de las actuaciones de control en estos espacios, favoreciendo la degradación de los componentes ambientales. En el resto de los espacios naturales protegidos reina un uso público anárquico, especialmente en el área litoral de la provincia de A Coruña, donde caravanas, coches, quads circulan y aparcan con total libertar sobre los ecosistemas dunares y la vegetación de los acantilados. La erosión generada por estas actuaciones año tras año, se visualiza en las fotografías aéreas de los espacios del área litoral, como zonas fuertemente erosionadas, donde la vegetación y los sedimentos arenosos han desaparecido completamente (ZEC Costa Artabra, ZEC Costa da Morte, ZEC Complexo Húmido de Corrubedo, ZEC Ons - O Grove, etc). En las áreas interiores la falta de un modelo adecuado de gestión del uso público lleva a autorizar rutas de escaladas en áreas muy sensibles por la presencia de hábitats especies y rupícolas Parque Natural da Enciña da Lastra (Rubiá, 
Ourense), o pruebas de barranquismo y triales en la Sierra do Courel (ZEC Os Ancares - O Courel).

En la información obtenida a través de las hemerotecas y de las páginas web de los grupos ambientalistas, hemos podido constatar la celebración, especialmente en la provincia de A Coruña, de toda una serie de actividades lúdicas sobre hábitats naturales - seminaturales (desbroces, romerías, fiestas, verbenas, actividades ecuestres, prácticas deportivas, uso de megafonía) que incumplen los objetivos de conservación de los espacios naturales, así como de las determinaciones contempladas en sus instrumentos de ordenación y en la normativa ambiental. Finalmente debemos señalar la ejecución de obras y proyectos planteados en espacios de la Red Natura 2000 ejecutadas al margen de las disposiciones contempladas en su artículo 6. Entre ellas destaca la realizada en la ZEC Estaca de Bares, donde en el año 2017 se ejecutaron distintas obras (aparcamiento de vehículos, aparcamiento de autobuses, viales peatonales, demoliciones, rellenos, desbroces), incluidas en un proyecto destinado a dotar el espacio de infraestructuras turísticas que no fue sometido al procedimiento evaluación acorde con la normativa europea (Directiva 92/43/CEE; Directiva 2001/42/CE; Directiva 2011/92/UE). De nuevo el modelo constructivo elegido por los responsables autonómico resulta totalmente incongruente con los valores de la biodiversidad y del Patrimonio Natural, provocando además en su ejecución una importante alteración de los hábitats naturales y de los hábitats de especies protegidas, obras que fueron denunciadas por la Sociedad Gallega de Historia Natural (www.sghn.org) ante la fiscalía de Medio Ambiente.

A.11.- Gobernanza. Los aspectos anteriormente expuestos gravitan a nuestro entender sobre un problema de Gobernanza es decir en la "buena forma de gobernar" de la autoridades. La gestión de la biodiversidad y de los espacios naturales gallegos, a excepción de aquellos que se ubican en la aguas marinas exteriores son competencias del gobierno de la Xunta de Galicia (Ley Orgánica 1/1981; Ley 1/1983), que la desarrolla a través de una única Dirección General (Dirección General de Patrimonio Natural, anteriormente denominada Dirección General de Conservación de la Naturaleza) que se ha integrado dependiendo de los gobierno dentro de la esfera de la Consejería de Agricultura (Medio Rural) o formando parte de la Consejería de Medio Ambiente. La dirección, subdirección han estado ocupadas por personas de libre designación, que en las etapas iniciales cuando la Dirección Xeral estaba englobada en Consejerías de la rama de agricultura, eran en su mayoría Ingenieros de Montes, mientras que en las etapas más recientes al ser integrada en la consejería de Medio Ambiente los perfiles académicos y profesionales poco tienen que ver con el medio ambiente y el Patrimonio Natural. En los servicios provinciales se repite la misma situación, de modo que a diferencia de otros territorios europeos es difícil identificar entre el staff técnico personas con una reconocida trayectoria profesional en el ámbito de la biodiversidad. A esta extraña situación se une la inexistencia de equipos técnicos encargados de acometer las labores de conservación, gestión, mientras que las labores de vigilancia son encomendadas a una guardería ambiental no estructurada profesionalmente y en la que no existen puestos para personal técnico o especializado. Hasta el año 2013, los Parques eran los únicos espacios naturales de Galicia que contaban con un pequeño staff de personal técnico y auxiliar, al frente del que se encontraba un director. Este modelo equiparable al que funciona en la mayoría de los Parques del planeta no alcanzó las dimensiones que podemos tener en los Parques de Bélgica o en los existentes en otros países de la Unión Europea, pero a pesar de sus limitaciones estructurales y económicas fueron capaces de llevar a cabo numerosas actuaciones de conservación, restauración y control del uso público, de la que queda una amplia constancia en distintas publicaciones científicas, así como de divulgación ampliamente divulgadas (Rodríguez Brea, 1993; Pulgar Sañudo, 2004; Amigo et al. 2005; Domínguez Conde, 2006; Galán Regalado, 2006; Reza Rodríguez, 2006; Novoa et al., 2009, Regos et al. 2012; Sauquillo, 2011; López Fernández et al. 2014, etc).

En el año 2013 la Xunta de Galicia decide eliminar la figura de Directores de Parques Naturales, manteniendo únicamente la de Parque Nacional, creando en sustitución una figura política a modo de un comisario que dirige todos los Parques Naturales gallegos, este sistema ha demostrado su total nulidad, repercutiendo de forma muy negativa en el cumplimiento de los objetivos y fines de estos espacios. Los problemas de gobernabilidad no afectan únicamente a los aspectos de estructura y de capacitación y conocimientos de los personas que ocupan los cargos de responsabilidad, sino que trasciende a la toma de decisiones de carácter técnico que son sin embargo decididas por personal de perfil político, que de acuerdo con los epígrafes anteriores resultan son la causa de graves desequilibrios en los sistemas naturales que provocan un estado de conservación desfavorable en los hábitats y las especies protegidas.

La acción aislada o sinérgica de los anteriores factores adversos incides con mayor virulencia sobre determinados componentes del ecosistema gallego provocando:

B.1.- Alteración y pérdida de ecosistemas: Uno de los elementos clave de la pérdida de biodiversidad está relacionado con el estado de conservación de los hábitats. Las pérdidas de su superficie, la fragmentación, la modificación periódica o permanente de su estructura, la alteración de su composición biológica y las modificaciones de su funcionamiento ecológico, determinan que el estado de conservación sea desfavorable, lo que supone un desequilibrio de los sistemas naturales que se define como un estado de conservación desfavorable. La Directiva Hábitat establece a través del artículo 6 un régimen estricto para evitar estas actuaciones en relación con los hábitats considerados como prioritario, prohibiendo de forma implícita la realización de cualquier actuación que pueda ser responsable de las mismas, mientras que en el caso de los hábitats de interés comunitario supedita la posibilidad de autorización a una adecuada evaluación ambiental.

En Galicia la pérdida de hábitats prioritarios y de interés comunitario en los espacios naturales y concretamente en los espacios de la Red Natura 2000 constituye una actividad 
generalizada que se realiza al margen de la determinaciones establecidas en la Directiva Hábitat, así como de las propias normativas estatales y autonómicas. En una reunión internacional sobre la protección del Bosque Atlántico (Izco, 1994), realizada previa a la configuración de la Red Natura 2000 de Galicia, se ponía en evidencia la importancia de los bosques de robles caducifolios y marcescentes de la fachada Atlántica europea y especialmente los del área galaicoportuguesa, dada su abundancia de especies endémicas, raras y amenazadas de flora y fauna. Transcurridos más de 25 años, la situación del Bosque Atlántico en Galicia ha sufrido un fuerte detrimento, aunque persisten importantes superficies de bosques antiguos en algunos espacios naturales gallegos, como el Parque Natural das Fragas do Eume, o la ZEC Os Ancares - O Courel, se evidencia importantes pérdidas de superficie y sobre todo alteraciones de su estructura de cara a una gestión o aprovechamiento contraria con los objetivos de conservación de un bosque. La situación se hace más dramática fuera del ámbito de los espacios naturales, donde de forma habitual se eliminan masas de bosques antiguos y bosques maduros para ser sustituidos por formaciones de eucaliptos, o simplemente para incrementar la superficie agraria útil y poder así percibir las ayudas de la Comisión Europea. En la actualidad los bosques nativos tanto de robles como dominados por otras especies caducifolias (abedules, alisedas, fresnedas, hayedos, saucedas, etc), como perennifolios (acebedas, alcornocales, encinares, lauredales, madroñales, tejedas), así como las formaciones seminaturales de castaños (castañares), muestran en conjunto un superficie inferior a la que ocupa los eucaliptales (Eucalyptus globulus), que se han convertido en la formación leñosa dominante en el paisaje de Galicia y cuyos efectos negativos mal identificados inicialmente (Bara Temes, 1985), se muestran en la actualidad apoyados en numerosas evidencias científicas (Codero-Rivera, 2019; Díaz-Fierros, 2019; González Prieto, 2019).

Un segundo grupo de hábitats que ha mermados de forma muy significativa su presencia en los espacios naturales de Galicia y en general en el conjunto del territorios gallego son los matorrales. Hay que resaltar que muchas de los ecosistemas de matorral gallego tienen una elevada biodiversidad, dependiendo de ellos un gran número de especies endémicas, raras y amenazadas de flora y fauna. Algunas de estas formaciones de matorral poseen a nivel

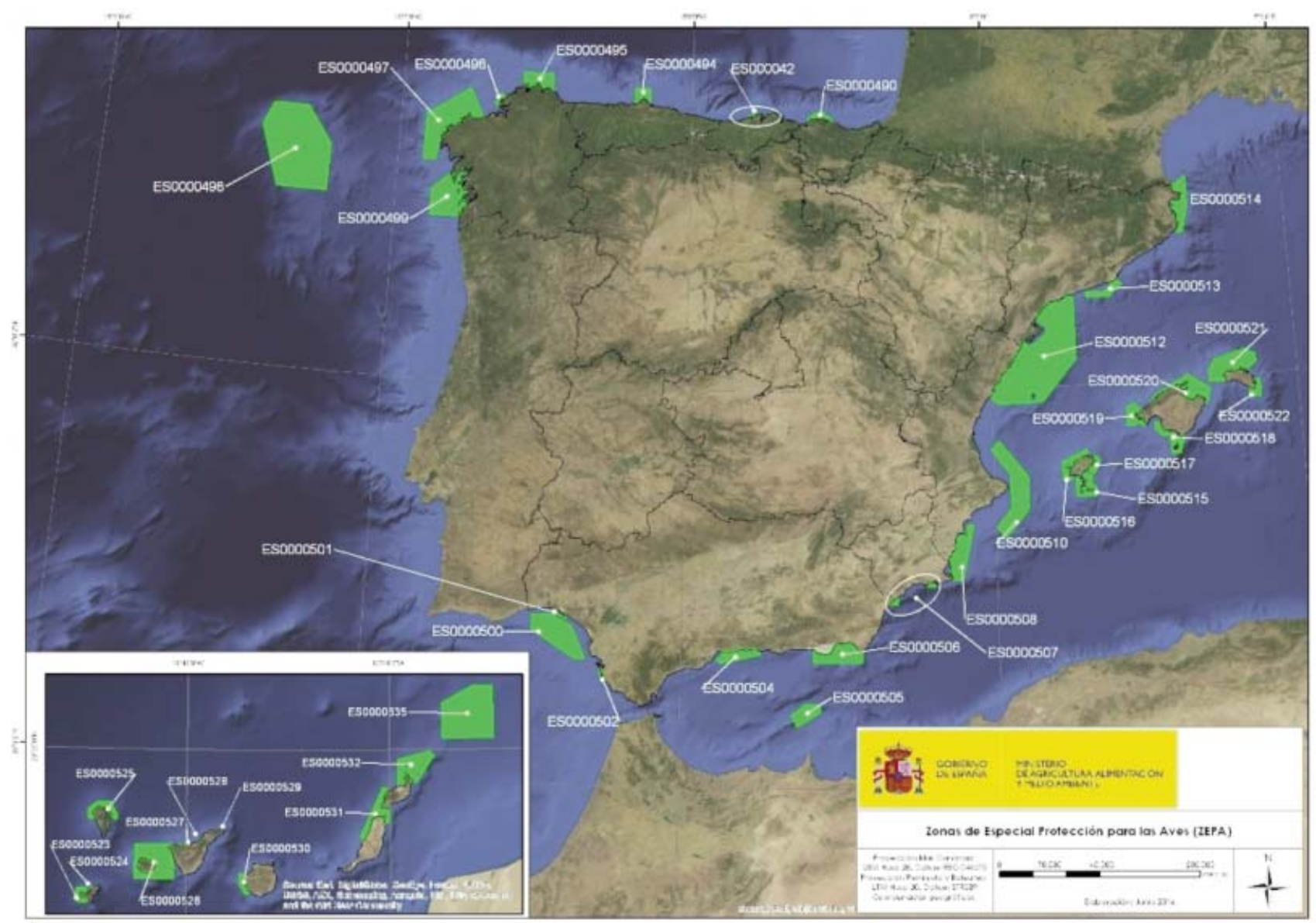

Figura 3.- Mapa de las 39 ZEPA pertenecientes a la Red Natura 2000 en el ámbito marino declaradas por el Estado. Cuatro de estas ZEPAS se corresponden a Galicia e incluyen aguas marinas interiores (Rías, áreas de contacto con el margen costero) asía como aguas marinas exteriores. Fuente Ministerio Para la Transición Ecológica (2019) 
una escasa área de distribución que se concentra en el NW Ibérico y en concreto en Galicia. Pese a estas características y al hecho de que la mayoría de las formaciones de matorral de leguminosas espinosas (Ulex, Genista, Cytisus) y distintas ericáceas (Calluna, Daboecia, Erica) son consideras como hábitats de interés comunitario y algunas de ellas como prioritarias (Izco et al. 2006; RamilRego et al. 2008b). El análisis de fotogramas aéreos revela una fuerte reducción de los matorrales representativos de hábitats del Anexo I de la Directiva 92/43/CEE, en todo el territorio gallego. Una anómala situación que se agrava en algunos espacios de la Red Natura 2000 (Ancares-Courel, Baixa Limia-Serra do Xurés, Brañas do Xestoso, Fragas do Eume, Macizo Central, Serra do Candan, Serra do Careón, Serra do Xistral, etc.).

Un tercer grupo de hábitats que muestran en Galicia un estado de conservación desfavorable vinculado con reducción de sus superficies, fragmentación, o alteración de su estructuras y funciones ecológicas son los hábitats litorales. El crecimiento urbano se muestra en Galicia totalmente incompatible con la preservación de los medios dunares que han desaparecido de las designadas como "playas urbanas", remplazados por monumentales y costosos paseos marítimos, así como sistemas de playas destinados a un turismo masivo. Desgraciadamente este mismo modelo se ha ido extendiendo fuera de las ciudades causando graves desequilibrios de los ecosistemas litorales. La mayoría de estas playas urbanas de Galicia han sido galardonadas con la "bandera azul", un distintivo de carácter privado instaurado por la Asociación de Educación Ambiental y del Consumidor (ADEAC), gestionado en la actualidad a través de la Fundación para la Educación Ambiental (FEA), aunque muchas de ellas son enclaves que no deberían tener ninguna mención de carácter ambiental. Fuera de las áreas urbanas el turismo de sol y playa llevo a una progresiva y desmesurada urbanización de los tramos litorales con playas, en la que una importante superficie de dunas fue destruida para construir viales, aparcamientos, miradores, plazas y jardines, y todo tipo de infraestructuras. Las áreas dunares no afectadas por los paseos, el acceso indiscriminado de personas, cuando no de vehículos, así como la ejecución de continuos desbroces, ha provocado una importante degradación de los hábitats de dunas blancas y dunas grises. A los que se suma en el caso de las dunas embrionarias las consecuencia de las limpiezas mecanizadas que se efectúan en el periodo estival. La alteración del medio unido a las condiciones climáticas favorece que en muchos de estos ecosistemas se hayan expandido diferentes especies exóticas invasoras. Las actuaciones realizadas sobre estas se han centrado mayoritariamente en el Parque Nacional das Illas Atlánticas y en el Parque Natural de Corrubedo, mientras que por el contrario apenas existen acciones de control en el resto de los espacios, donde las especies invasoras invaden las áreas más frecuentemente frecuentadas por los turistas.

La Región Atlántica Ibérica se diferencia de la Mediterránea por una mayor abundancia de precipitaciones sin registrar un periodo de sequía estival. La abundancia de agua y las condiciones geológicas determinan la existencia de un amplio número de humedales, tanto en las áreas litorales como interiores. Galicia es la Comunidad Autónoma con mayor número de humedales de España. Los tipos de humedales identificados en Galicia se correlacionan directamente con la clasificación de humedales de la Convención de Ramsar (1971), así como con los tipos de hábitats de la Red Natura 2000 (Directiva 92/43/CEE). En un reciente trabajo publicado por el IBADER (Ramil-Rego et al. 2017), se constata el estado de conservación desfavorable de los humedales gallego, tanto dentro como fuera de la Red Natural. Las agresiones más importantes se corresponden con la construcción de parques eólicos y sus infraestructuras, las transformaciones para el establecimiento de explotaciones intensivas ganaderas, agrícolas o forestales (Eucalyptus). De los más de 1.100 humedales gallegos, 5 han sido inscriptos en la Lista de Humedales de Importancia Internacional de la Convención de Ramsar (RCS, 1971; Instrumento de Adhesión de España, 18/03/1982; Real Decreto 435/2004; Ramil-Rego \& Izco, 2003), siendo además declarados por el gobierno de Galicia como "Humedales Protegido" (Decreto 110/2004; Decreto 127/208), formando además parte de la Red Natura 2000. A pesar de las numerosas figuras de protección que inciden sobre estos humedales el estado de conservación de este no puede considerarse como favorable. A las pérdidas de superficies de hábitats y la alteración o destrucción de los hábitats de las especies protegidas, se suman problemas de contaminación de las aguas, de expansión de especies exóticas, así como alteraciones del funcionamiento ecológico y una inadecuada gestión del uso público.

Entre los humedales Ramsar resulta alarmante la situación en la que se encuentra el Humedal de A Frouxeira, enclavado en el litoral de la Costa Ártabra entre Ferrol y Cedeira, que hemos podido visitar en distintas ocasiones. En este humedal se realizó un paseo marítimo que discurre por menos de la mitad del perímetro del lago. El diseño erróneo de este paseo determina que quede ordinariamente inundado en invierno al incrementarse el volumen de agua retenida en la laguna. Para resolver esta situación en lugar de eliminar o modificar el paseo la administración autonómica opta por llevar a cabo año tras año distintas aperturas de la laguna. Este procedimiento resulta incongruente con el artículo 6 de la DC 92/43/CEE ya que en ningúnn momento se ha sometido a evaluación ambiental y su acción continuada interfiere de forma apreciable el funcionamiento del humedal (Frouxeira: Muñiz, 2012, 2016). La Xunta de Galicia aprobó para este humedal un Plan de Conservación que incluye un protocolo para la apertura no reiterada y continua del lago, que no se está cumpliendo, llegándose a realizar las aperturas en los periodos invernales de 2017-2018, 2018-2019. 2019-2020 de forma contraria al mencionado protocolo. Como consecuencia el régimen ecológico del humedal se muestra anómalo en relación con el resto de las lagunas costeras de la Región Atlántica, manteniéndose sin apenas aguas, situación que es aprovechada ocasionalmente por alguna ave que deleita a los aficionados a la ornitología, pero que supone un grave y continuo desequilibrio natural de los sistemas natural, y por consiguiente un estado de conservación muy desfavorable. 
Aunque la alteración y pérdida de humedales resulta muy grave en las áreas litorales, también se registra de forma notoria en interior de Galicia, donde hemos podido constatar pérdidas muy significativas de hábitats prioritarios, como turberas activas (Raised Bog, Blanket Bog) y de brezales húmedos, vinculadas a explotaciones de turba para fines hortícolas, la transformación a pastizales y la forestación con Eucalyptus. La turberas y los ecosistemas de montaña se han visto además alterados de forma muy significativa por la construcción de los parques eólicos y las infraestructuras vinculadas con estas.

En los cursos fluviales de nuevo son las alteraciones humanas vinculadas con construcciones (minicentrales, playas fluviales, paseos fluviales), así como el inadecuado manejo que se realiza de las riberas (desbroces periódicos, instalación de cultivos agrícolas y forestales) y la falta de una adecuada depuración de las aguas procedentes de núcleos urbanos y rurales, polígonos y establecimientos industriales, explotaciones ganaderas, las que determinan un estado de conservación muy deficiente. A mayores los ríos gallegos han sido diezmados en los últimos diez años por la expansión de distintas especies exóticas y especialmente de hongo patógeno, Phytophthora alni, que afecta a uno de los elementos indicativos del hábitat prioritario 91E0*, siendo muy escasos los corredores fluviales de los grandes ríos que recorren los espacios naturales gallegos no han sido afectados por esta plaga. Desgraciadamente los corredores fluviales se encuentran en Galicia en un estado de conservación desfavorable.

B.2.- Alteración y pérdida de hábitats y núcleos poblaciones de especies protegidas. Vinculada a la pérdida de hábitats se detecta también una importante pérdida de núcleos poblacionales de especies protegidas, así como alteración o pérdida de sus hábitats. La Xunta de Galicia ha sido incapaz de paliar el mal estado de conservación en el que se encontraban algunas especies singulares de la biodiversidad gallega. Ha sida tras una serie de intervenciones desafortunadas en el año 2005 se daba por extinta en Galicia la población más accidental de subespecie cantábrica del urogallo, Tetrao urogallus L. subsp. cantabricus Castroviejo (Callejo \& Santamarina, 2006), no reflejándose como extinta en el Catálogo Gallego de Especies Amenazadas (Decreto 88/2007), donde fue incluida como "En Peligro de Extinción", categoría que todavía mantiene en la actualidad. La falta de medidas de conservación efectivas que determinaron la extinción del urogallo en Galicia se puede extender a otros especies, tanto del ámbito marino, especialmente en relación con aves marinas, tortugas marinas y cetáceos, así como en los medios terrestres. A pesar de que muchas especies de flora y fauna consideradas como amenazadas forman parte del Catálogo Gallego de Especies Amenazadas (Decreto 88/2007), el número de Planes de Conservación o Planes de Restauración aprobados por la administración autonómica desde la entrada en vigor de este es mínimo, y no existe previsión de que se puedan aprobar a corto o medio plazo. Esta situación supone un incumplimiento de la normativa vigente, y deja al borde de la extinción a muchas de las especies protegidas de flora y fauna silvestre.
El Catálogo Gallego de Especies Amenazadas (Decreto $88 / 2007$ ), ha dejado sin incluir especies que en la actualidad en Galicia no muestran un estado de conservación favorable debido a la presión ejercida o que puedan ejercer distintos colectivos. Entre ellas llama la atención la no inclusión del salmón Atlántico (Salmo salar L.), al borde de su extinción, habiendo desparecido en los últimos 80 años de la mayoría de sus localidades de presencia. Los intentos de favorecer la especie llevaron al implementar una campaña de reforzamiento poblacional a partir de individuos obtenidos mezclando procedencias gallegas y extranjeras. El lobo ibérico (Canis lupus) tampoco figura en el Catálogo Gallego de Especies Amenazadas (Decreto 88/2007) aunque el análisis de su estatus poblacional obligarían a incluirlo. En este sentido resulta ilógica la diferenciación que en relación con esta especie se plantea en la Directiva Hábitat, en la que solamente se contempla como especie protegidas las poblaciones situadas al sur del Duero. Esta disyunción fue una imposición del Gobierno Español no sustentada con datos científico-técnicos que con el paso del tiempo ha resultado muy perjudicial para la conservación de esta especie.

En cuanto a las reintroducciones de antiguas especies extintas estas se refieren mayoritariamente a la cabra montés o íbice ibérico que mantenía poblaciones en las Sierras Orientales de Galicia y el Norte de Portugal, consideradas como una subespecie diferenciada de las del resto de la Península Ibérica (Capra pyrenaica subsp lusitanica). Tras el exterminio de la subespecie por la presión cinegética, la Xunta de Galicia llevo a cabo un plan de reintroducción de la cabra montés, adquiriendo para ello individuos en Castilla-León de filiación genética desconocida que fueron liberados en el Parque Natural de Baixa Limia - Sierra de Xurés, pasando rápidamente a colonizar el área contigua del Parque Nacional de Peneda Gerês.

Frente a la abundancia de datos negativos sobre la gestión de las especies amenazadas de Galicia, queremos también destacar algunas acciones positivas, muchas de ellas vinculadas con los escasos planes de conservación aprobados y las actuaciones vinculadas con proyectos financiados por el programa LIFE - Nature o la Fundación Biodiversidad. Entre las primeras cabe resaltas las actuaciones de monitoreo y gestión del chorlitejo patinegro. (Charadrius alexandrinus), el escribano palustre (Emberiza schoeniclus), el galápago europeo (Emis orbicularis). Entre los segundos destacan las relacionadas con el oso cantábrico (Ursus arctos cantabricus), en el área oriental de Galicia a través del proyecto LFEE Oso Courel, las acciones vinculadas con distintas botánicas amenazadas de humedales (LIFE Tremedal) o con los bosques de tejo (Life Baccata).

\section{As brétemas eternas da política ambiental galega}

La Ley 9/2001 constituyó durante 18 años la norma básica sobre la conservación de la naturaleza en Galicia, sin sufrir apenas modificaciones a pesar de que a lo largo del periodo en que estuvo vigente se produjeron importantes cambios 
en la política ambiental tanto a nivel internacional, europea y estatal. Esta situación refleja la aptitud tibia de los responsables de la Xunta de Galicia y su escasa preocupación por llevar a cabo una gestión y planificación adaptativa y racional de los recursos naturales y de la biodiversidad. En septiembre de 2019, la Ley 9/2001 es derogada y sustituida por la Ley $5 / 2019$, de 2 de agosto, del patrimonio natural y de la biodiversidad de Galicia. La elaboración de este nuevo marco legal se realizó sin apenas participación de entidades y colectivos vinculadas con la conservación de la naturaleza, y a tenor del contenido de esta debió contar con una reducida y deficiente asesoría legal y técnica.

La Ley 5/2019, consta de 4 títulos, 20 capítulos y 136 artículos, junto con 5 disposiciones adicionales, 8 disposiciones transitorias, 1 disposición derogatoria y 6 disposiciones finales. La estructura resulta mucho más compleja a la de la anterior norma gallega, pero también frente a la normativa estatal, la Ley 42/2007 (3 Títulos, 16 Capítulos, 79 artículos), a pesar de que el legislador gallego asumía irónicamente en el preámbulo el objetivo de promover una normativa que "sin resultar excesiva o deficitaria en su regulación, y estableciendo un marco jurídico claro y fácilmente comprensible para los distintos destinatarios". Parte de la fragosidad del texto deriva de la incorporación de las disposiciones contenidas en distintos Reales Decreto. Este proceder no parece el más adecuado jurídicamente, ya que la previsible modificación de estas normativas obligará a modificar de forma sincrónica la ley gallega, con la posibilidad de que estos cambios se demoren en el tiempo y se generen incongruencias entre la norma autonómica y estatal.

El Título I hacer referencia a las Disposiciones Generales, fijando los objetivos, ámbito de aplicación y principios generales de la ley, entre los cuales se consolida la prevalencia de la protección ambiental sobre la ordenación territorial y urbanística, la precaución respecto a las posibles intervenciones que puedan afectar negativamente al patrimonio natural o a la biodiversidad, y la prevención de los problemas derivados del cambio climático. Resulta anómalo que en este Título al igual que en el Preámbulo no existe ninguna referencia al Convenio de Diversidad Biológica, y se aludan otros que tienen una importancia menos en relación con los objetivos que aquí se contemplan. El Título II a los Espacios Naturales Protegidos del cual posteriormente analizaremos algunos aspectos. El Título III se dedica a la Conservación de las especies (Capítulo I) y de los hábitats (Capítulo II), siguiendo en gran medida los aspectos ya contemplados en la normativa europea y estatal. Lo mismo ocurre con el último título, el Título IV, está dedicado a la Inspección y régimen sancionador.

Uno de los aspectos positivos de la Ley 42/2007 se muestra en el esfuerzo de armonizar las distintas figuras de áreas protegidas (Espacios Naturales Protegidos, Espacios Protegidos de la Red Natura 2000, Áreas Protegidas por Instrumentos Internacionales), adecuando además las mismas a los criterios internacionales propuestos por la IUCN \& WCMC (IUCN \& WCMC, 1994;) y asumidos por la mayoría de los países y organizaciones internacionales
(Bishop et al. 2004; Stolton \& Dudley, 2010; Day et al. 2012; Kothari et al. 2012; Borrini et al. 2013; Dudley et al. 2013;). El legislador gallego se muestra desorganizado y libertario frente a este aspecto de uniformidad, prefiriendo adoptar criterios y definiciones propias.

En la Ley $5 / 2019$, las áreas protegidas son abordadas en el Título II, que se designa como "Espacios Naturales Protegidos", incluyendo aquí tanto las categorías de Espacios Naturales Protegidos (Reserva Natural, Parque, Monumento natural, Humedal Protegido, Paisaje Protegido, Espacio Protegido Red Natura 2000, Espacio natural de interés local, Espacio privado de interés natural), como las Áreas Protegidas por Instrumentos Internacionales (Humedales de Importancia Internacional del Convenio de Ramsar, los Sitios Naturales de la Lista del Patrimonio Mundial de la UNESCO, las Áreas Protegidas de la Convención para la Protección del Medio Ambiente marino del Atlántico del Nordeste OSPAR, los Geoparques UNESCO, Reservas de la Biosfera UNESCO, Reservas Biogenéticas Consejo de Europa), que no poseen este estatus jurídico. En cuanto a los Espacios Naturales Protegidos, se incluyen como tales las categorías establecidas por la normativa estatal (Ley 42/2007), así como 4 de las 5 categorías contempladas en la Ley 9/2001. Eliminando ahora la categoría de Zona de Especial Protección de los Valores Naturales (ZEPVN) que había sido otorgada por el gobierno autonómico a los espacios gallegos de la Red Natura 2000. En el nuevo texto gallego, se mantiene la consideración de "Espacio Natural Protegido" a los sitios de la Red Natura 2000, bajo la denominación de "Espacio Protegido Red Natura 2000". El término elegido crea confusión con la normativa estatal (Ley 42/2007) y con las disposiciones de otras Comunidades Autónomas, al emplear esta categoría para otorgar a los lugares de la Red Natura 2000 un estatus jurídico de área protegida diferenciado de la Red Natura 2000. Alejándonos de nuevo del objetivo de establecer un marco jurídico claro y fácilmente comprensible para los distintos destinatario, que se asumía en el preámbulo.

El artículo 23 de la Ley 5/219, define las Reservas Naturales: 1.- Las Reservas Naturales son espacios naturales cuya declaración tiene como finalidad la protección de los ecosistemas, comunidades o elementos biológicos que, por su rareza, fragilidad, importancia o singularidad, merecen una valoración especial. En las reservas se limitará la explotación de recursos, salvo en aquellos casos en que esta explotación sea compatible con la conservación de los valores que se pretenden proteger. Con carácter general, se prohibirá la recolección de material biológico o geológico, excepto que se disponga de autorización específica previa para la realización de esta actividad por razones de investigación, conservación o educativas. 2.- Cuando alguna zona incluida en la Reserva Natural contenga ecosistemas o comunidades en un estado de conservación que requiera una protección absoluta, podrá ser declarada zona de reserva natural integral. En estas zonas se prohibirá cualquier tipo de aprovechamiento y se restringirá el acceso público, garantizando la mínima intervención exterior posible, salvo las medidas de conservación, gestión y, en su caso, de investigación que se 
estimen pertinentes. 3.- Como una categoría específica de las Reservas Naturales, podrán declararse como Refugios de Vida Silvestre-microrreservas aquellos espacios de superficie inferior a veinte hectáreas y referidos a toda o una parte del hábitat en el que vive una especie, subespecie o población y que contengan hábitats raros o que constituyan el hábitat de especies amenazadas y cuya conservación resulte de especial importancia. Del mismo modo, mediante la aprobación de planes, podrán establecerse medidas de conservación de carácter temporal o permanente en áreas de pequeña extensión al objeto de garantizar un estado de conservación favorable para las especies de flora y fauna catalogadas. Asimismo, en las áreas críticas se adoptarán medidas de conservación e instrumentos de gestión específicos para estas áreas o integrados en otros planes, que eviten las afecciones negativas para las especies que motivaron la designación de estas áreas (art. 23).

En las normativas autonómicas previas a la Ley 42/2007 el tratamiento de las Reservas Naturales se mostraba muy desigual, devaluando en muchos casos los objetivos de esta hasta plantear su homología con la figura franquista de Reserva Nacional de Caza (Ley 37/1966) o los Refugios de Fauna, surgiendo así distintos tipos de denominaciones o subcategorías de Reservas Naturales: Reserva Parcial, Reserva Integral, etc. El primer punto de la definición de Reserva Natural incluido en la Ley $5 / 2019$ es una transposición directa del artículo 31 de la Ley 42/2007 del Estado, mientras que el resto de los puntos son de cosecha del legislador gallego y que entran en conflicto la definición de Reserva Natural planteada por la IUCN y refrendado por el legislador estatal. El legislador gallego desnaturaliza y deprava el concepto de Reserva Natural, de modo que las características propias de una Reserva Natural, solamente se mantendría en aquellas áreas clasificadas como "zona de reserva integral", pudiéndose declarar una Reserva Natural sin una zona de reserva integral, lo que supone equipara una Reserva Natural con un Paisaje Protegido o con un que se declare en el territorio gallego carente de dicha unidad de zonificación, lo que lleva a relegar el concepto de Reserva Natural y equipararlo con el de un Paisaje Protegido o de una Área protegida manejada La confusión de conceptos que muestra el redactor del texto gallego pone en evidencia su falta de conocimientos en materia de áreas protegidas y de conservación de la naturaleza.

La impericia de legislador gallego lleva además a considerar como subcategorías de la Reserva Natural, las "Microrreservas" y los, dos subcategorías que todavía desvirtúan más esta figura los Refugios de Vida Silvestre. y las Microrreservas. Sobre la primera subcategoría la Ley 5/2019 es parca en información. El término que la designa deriva de la categoría americana: National Wildlife Refuge, creada en 1903 durante el mandato de Theodore Roosevelt, integrando en la actualidad más de 562 lugares que abarcan una superficie de $607.028 \mathrm{~km} 2$, con una media de $1.080 \mathrm{~km} 2$ por Refugio, mientras que el legislador gallego plantea que estos tengan con máximo una superficie de 20 ha. La categoría de Refugio de Vida Silvestre fue adoptada en distintos países anglosajones, así como en muchos países latinoamericanos. Otorgando a estos espacios siempre grandes superficies, incluso muy superiores a las que caracterizan los Parques Nacionales.

En cuanto a la subcategoría de Microrreserva, su concepto y características asumidas internacionalmente difieren completamente frente al modelo planteado por el legislador gallego. El concepto de microrreserva fue establecido en 1990 por un grupo de botánicos valencianos dirigido por el Dr. Emilio Laguna, desarrollándolo entre 1994-1997 a través de un programa Life de la Unión Europea (Laguna, 1998, 2001). Paralelamente mediante Decreto 2018/1994/CV, se creó la figura de "protección de especies" denominada microrreserva vegetal que permite una protección estricta, y permanente, de especies botánicas raras, endémicas o amenazadas, o las unidades de vegetación que la contienen, así como sus sustratos, en pequeños enclaves del territorio valenciano ( $<20 \mathrm{ha}$ ). La declaración de un Microrreserva tiene como finalidad dotar de mayor grado de protección legal y permanencia a parcelas experimentales de investigación botánica o forestal. Conservar las "localidades clásicas botánicas", es decir, los sitios donde por primera vez fueron descubiertas para la ciencia nuevas especies, muchas de ellas exclusivas de la Comunidad Valenciana a nivel mundial. Favorecer la conservación de los sustratos sobre los que crece la vegetación, y en especial los perfiles-tipo geológicos o de suelos. Preservar inventarios sobresalientes de unidades de vegetación protegidos por la Directiva de Hábitats de la Unión Europea. Conservar, individualmente 0 en conjunto, árboles monumentales o singulares que crecen sobre terrenos naturales, así como árboles-élite, árboles-plus u otros destinados a la investigación forestal. Preservar recorridos botánicos didácticos y rutas ecológicas para la docencia botánica. $Y$ facilitar las reintroducciones o reforzamientos poblacionales de plantas amenazadas o en peligro de extinción. En la microrreserva se encuentran protegidas las plantas y los sustratos sobre las que éstas crecen (suelo, roca, etc.), y en ocasiones se pueden establecerse medidas adicionales para proteger a aquellas especies de animales (especialmente insectos) que resultan necesarios para la supervivencia de las plantas, al garantizar la polinización de las flores, la dispersión de las semillas, etc. Una microrreserva se declara mediante Orden, que se publica en el Diario Oficial de la Generalitat Valenciana. Previamente, equipos mixtos de técnicos e investigadores botánicos han determinado zonas idóneas, han inventariado su contenido vegetal, han delimitado topográficamente sus límites y han procedido a señalizarlos provisionalmente mediante piquetas señalizadoras. En el trámite de la declaración se solicita la opinión de las entidades propietarias o gestoras del terreno, de las universidades y centros de investigación, y de las entidades conservacionistas debidamente legalizadas que actúen habitualmente sobre esa zona. Las entidades públicas y privadas pueden recibir ayudas de la Generalitat Valenciana para facilitar las labores de gestión y monitoreo de las microrreservas. Las "microrreservas" no son en Valencia "espacios naturales protegidos", y de este modo no figuran en la legislación autonómica que regula estas figuras (Ley 11/1994). A diferencia de los espacios naturales protegidos, las microrreservas se declaran con el fin de estudiar y realizar un seguimiento de la flora y la vegetación a largo 
plazo. La protección de la flora y el entorno físico es un medio para lograr sus fines. Por el contrario, en los espacios naturales protegidos, la protección constituye un fin en sí mismo. Por esta razón, también se declaran microrreservas de flora en el interior de espacios naturales protegidos. Tras más de 30 años de funcionamiento exitosos las Red de Microrreservas valencianas incluyendo más de 312 microrreservas (232 públicas y 80 privadas), manteniendo su estatus jurídico, diferenciado de un espacio natural protegido.
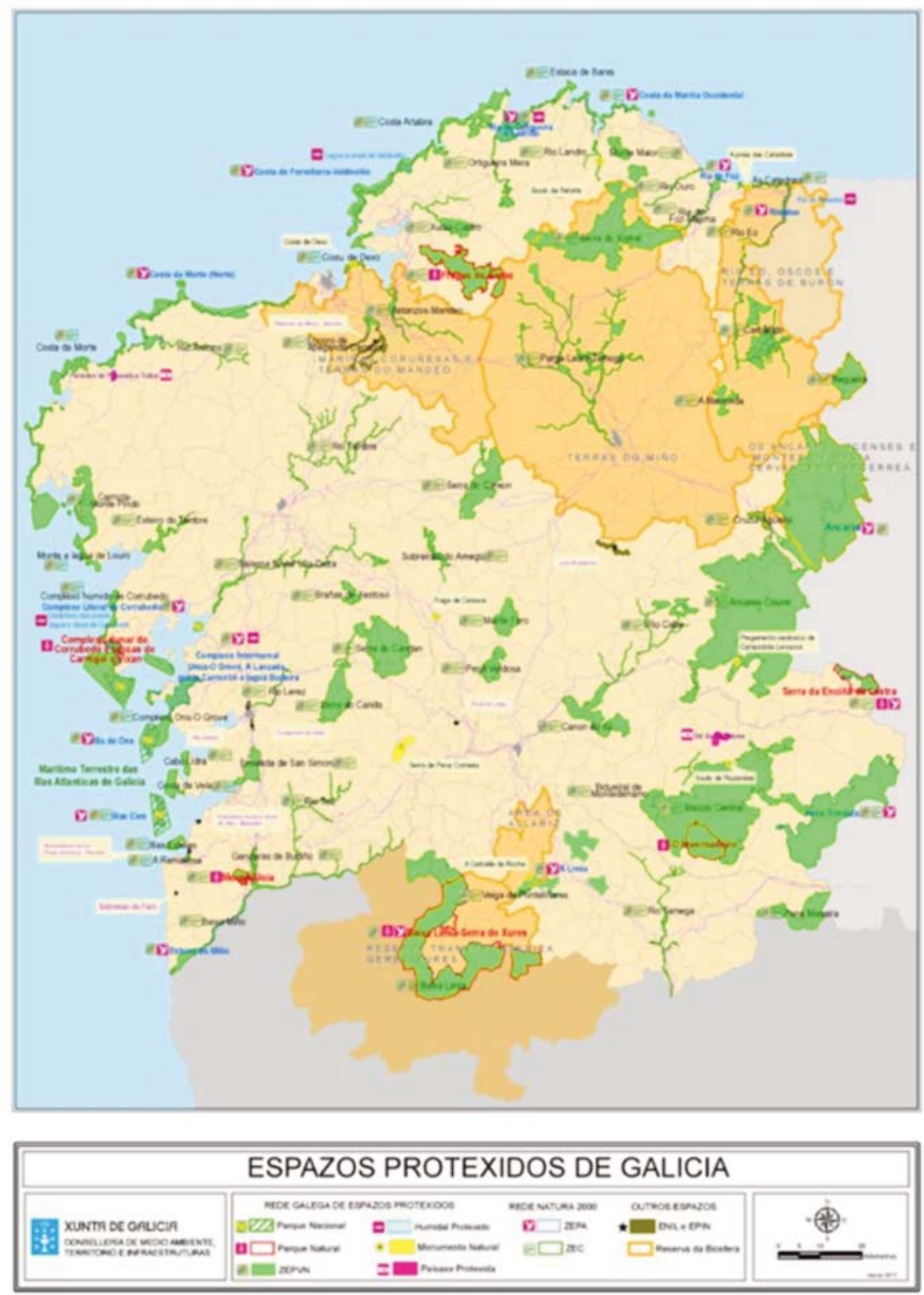

Figura 4.- Espacios Naturales gestionados por la Comunidad Autónoma de Galicia. Fuente Xunta de Galicia (2017) 
El modelo de Microrreservas valenciano ha sido adoptado con éxito en numerosos territorios europeos, centrándonos en España, aparece igualmente recogido en la legislación de Castilla y León, desde el año 2007, cuando se aprobó el Decreto 63/2007 que establecía asociado al Catálogo de Flora Protegida de Castilla y León y la figura de protección denominada Microrreserva de Flora. Posteriormente tras la aprobación de la Ley 4/2015 del Patrimonio Natural de Castilla y León, son integradas en la Red de Zonas Naturales de Interés Especial, junto con los montes catalogados, las vías pecuarias, las zonas naturales de esparcimiento, los árboles notables y los lugares geológicos y paleontológicos de interés especial, manteniendo su diferencia jurídica frente a los Espacios Naturales Protegidos, los Espacios de la Red Natura 2000, las Reservas de la Biosfera o los Humedales de la Convención de Ramsar.

La Ley 9/1999 de Conservación de la Naturaleza de Castilla - La Mancha, incluye 7 figuras de Espacios Naturales Protegidos, cinco de ellas coincidentes con la normativa estatal (Reservas Naturales, Parques Nacionales, Parques Naturales, Monumentos Naturales, Paisaje Protegido) y otras dos figuras de ámbito autonómico (Reservas Fluviales, Microrreservas). Definiéndose las microrreservas como: Las microrreservas son espacios naturales de pequeño tamaño que contienen hábitats raros, o bien conforman el hábitat de poblaciones de especies de fauna o flora amenazadas, resultando especialmente importante su protección estricta. Actualmente la Comunidad Autónoma de Castilla - La Mancha posee 48 microrreservas que incluyen desde pequeños humedales, espacios de interés para la conservación de especies de flora amenazadas, zonas de cría y descanso de mucilagos, así como distintos medios artificiales.

La Ley 5/219, mantiene el criterio de 20,0 ha fijado en la normativa valenciana para las microrreservas, pero el legislador gallego decide definirlas como espacio natural protegido, al igual que en la normativa de Castilla - La Mancha, pero diferenciándose de esta al asignarla al espacio natural protegido con mayor nivel de restricción, la Reserva Natural. El otorgamiento de este nivel máximo de protección conduce a una dificultad elevada en el procedimiento de declaración y de elaboración y aprobación del instrumento de gestión (PORN) que contrasta con la intención del legislador gallego de plantear la posibilidad de que existan microrreservas permanentes y temporales como modalidades de Reservas Naturales. Estamos pues ante un sinsentido conceptual y normativo que determine que Galicia nunca posea un sistema de microrreservas semejante al existente en Valencia, Castilla-León o CastillaLa Mancha.

En la definición de Parque la Ley 5/2019, incorpora en su primer párrafo la definición contemplada en la Ley 42/2007, para añadir en los párrafos siguientes el reparto competencial en cuenta a la forma de declaración y gestión de los Parques Nacionales y Naturales, así como desarrolla las características de estos últimos:1.- Los parques son áreas naturales que, por la belleza de sus paisajes, la representatividad de sus ecosistemas o la singularidad de su flora, de su fauna o de su diversidad geológica, incluidas sus formaciones geomorfológicas, poseen unos valores ecológicos, estéticos, educativos o científicos cuya conservación merece una atención preferente. 2.- De acuerdo con el artículo 31.2 de la Ley 42/2007, de 13 de diciembre, del patrimonio natural y de la biodiversidad, los parques nacionales se regirán por su normativa específica, conforme a la cual la declaración se efectuará por ley de las Cortes Generales, correspondiendo a la Comunidad Autónoma de Galicia la gestión de los ubicados en su territorio en los términos previstos en dicha normativa. 3.Por su parte, la declaración de un espacio como parque natural corresponde a la Administración autonómica. La declaración de un espacio como parque natural requerirá, además de lo dispuesto en el apartado 1 de este artículo, que tenga una superficie continua y no fragmentada, suficiente para permitir que se mantengan sus características físicas y biológicas, y se asegure el funcionamiento de los procesos naturales presentes. A estos efectos, la superficie del parque natural, salvo en casos debidamente justificados, tendrá: a) como mínimo, dos mil quinientas hectáreas en parques naturales terrestres o marítimo-terrestres insulares, y b) como mínimo, diez mil hectáreas en parques naturales terrestres o marítimo-terrestres peninsulares. 4.- En los parques podrán limitarse los aprovechamientos de los recursos naturales, prohibiéndose en todo caso los que resulten incompatibles con las finalidades que justificaron su declaración. 5- En los parques se facilitará la entrada de visitantes con las limitaciones precisas para garantizar la conservación de sus valores naturales y para respetar los derechos de las personas titulares de los terrenos. 6.- La Red de parques naturales de Galicia, creada por Decreto 69/2016, de 19 de mayo, coordinará la gestión de estos espacios naturales protegidos (art. 24). El aspecto más llamativo de este artículo es el establecimiento de un límite mínimo de superficie para la declaración de un Parque Natural, un sinsentido que carece de fundamento ambiental, más aún en un país de las dimensiones de Galicia y donde ni hay suficientes Parques Naturales declarados, ni se han declarado muchos parques en los últimos años. Los intervalos incluidos en la Ley de aplicarse de forma retrospectiva no permitirían declarar la mayoría de los Parques Naturales de Galicia: Cíes (433,58 ha) Monte Aloia $(433,58 \mathrm{ha})$, Corrubedo $(996,25 \mathrm{ha}), \mathrm{O}$ Invernadeiro (5.722,0 ha), Fragas do Eume ( $9.126,0$ ha), ya que de todos ellos el único que cumpliría el intervalo marcado es Baixa Limia - Serra do Xurés (29.345,00 ha). Estamos pues ante una propuesta absurda que solamente parece responder a un objetivo claro, que no se declaren más Parques Naturales en Galicia.

En cuanto a los Monumentos Naturales los tres párrafos iniciales del artículo 25 de la Ley 5/2009, transponen el artículo 34 de la Ley 42/2007. El legislador gallego incorpora además al artículo 25 la creación del Inventario Gallego de Lugares de Interés Geomorfológico: 4.- Se crea el Inventario gallego de lugares de interés geomorfológico como registro público de carácter administrativo dependiente de la consejería competente en materia de conservación del patrimonio natural. En este inventario se incluirá la información actualizada sobre todos los espacios de carácter geomorfológico ubicados en el territorio de la 
Comunidad Autónoma de Galicia que cumplan los requisitos establecidos en la normativa básica estatal para su inclusión en el Inventario español de lugares de interés geomorfológico. La Administración autonómica comunicará la información recogida en este inventario, a efectos de su reflejo en el Inventario español de lugares de interés geomorfológico. El Inventario gallego de lugares de interés geomorfológico incorporará todos los monumentos naturales de carácter geomorfológico (artículo 25). Resulta llamativo la prevalencia del aspecto "geomorfológico" entre los elementos de la Geodiversidad, cuando lo lógico sería contemplar también los referiros a aspectos petrológicos, sedimentológicos, paleontólogos, que han quedado en consecuencia excluidos.

El artículo 26 de la Ley 9/2001, se refiere a los Humedales Protegidos; manteniendo la definición inicial incluida en el artículo 14 de la Ley 9/2001, añadiendo un tercer punto: 3.El Inventario de humedales de Galicia creado por Decreto $127 / 2008$, de 5 de junio, por el que se desarrolla el régimen jurídico de los humedales protegidos y se crea el Inventario de humedales de Galicia, incorporará todos los espacios naturales protegidos declarados en esta categoría (articulo 26). La previsión de declarar los 1100 humedales gallegos como Humedales Protegidos es un objetivo loable, pero desgraciadamente el legislador no ha marcado un límite temporal creíble para llevar a cabo este propósito, y dada la velocidad de destrucción que sufren estos ecosistemas en Galicia probablemente en muchos casos ya no quede mucho que proteger y declarar.

En la definición de Paisaje Protegido, la normativa gallega (Leu 5/2019) se aparta de la definición estatal (Ley 42/2007) derivada de la Convención del Paisaje, para nadar en una ambigüedad política-clientelar entre las necesidades de conservación vs actividades socioeconómicas, cuyo planteamiento se realiza de forma nebulosa: 1.- Los paisajes protegidos son espacios que, por sus valores naturales, estéticos y culturales y de acuerdo con el Convenio del paisaje del Consejo de Europa, sean merecedores de una protección especial. 2.- En los paisajes protegidos se procurará el mantenimiento de las prácticas tradicionales que contribuyan a la preservación de sus valores y recursos naturales, y a la conservación de las relaciones y de los procesos, tanto naturales como socioeconómicos, que contribuyeron a su formación y hacen posible su mantenimiento (art. 27).

La categoría de "Espacio Protegido Red Natura 2000" se corresponde en la Ley 5/2019 con una figura autonómica de Espacio Natural Protegido. En la que se integran LIC, ZEC, ZEPA: "Los espacios protegidos Red Natura 2000 competencia de la Comunidad Autónoma de Galicia estarán constituidos por: a) Los lugares de importancia comunitaria, hasta su transformación en zonas especiales de conservación. b) Las zonas especiales de conservación, y c) Las zonas de especial protección para las aves (art. 28). De este modo gozaran de la condición de Espacio Natural Protegido, las propuestas de Lugares de Importancia Comunitaria desde el momento en que sean recibidas / enviadas a la Comisión Europea.
La Ley 5/2019, mantiene como las figuras de Espacio Natural Protegido los Espacios Naturales de Interés Local (art. 29) y los Espacios Privados de Interés Natural (art 30), cambiando parcialmente sus definiciones y obligaciones: Espacio natural de interés local: "1.- Son espacios naturales de interés local aquellos espacios integrados en uno o varios términos municipales que por sus singularidades sean merecedores de algún tipo de protección de sus valores naturales a nivel local. 2.- La responsabilidad y competencia en la gestión de estos espacios corresponderá a las entidades locales, en su ámbito territorial respectivo. 3.- Las entidades locales podrán constituir consorcios, mancomunidades $u$ otras modalidades asociativas para la gestión de estos espacios y podrán suscribir acuerdos de cesión total o parcial de su gestión con entidades de custodia del territorio, sin que dichos acuerdos alteren el régimen de responsabilidad previsto en el apartado anterior. 4.- Estos espacios no se considerarán incluidos en la Red gallega de espacios protegidos, y su declaración como espacios naturales protegidos no implicará la asignación de recursos de la Comunidad Autónoma de Galicia, aunque podrán tener preferencia en la obtención de ayudas para su conservación y gestión. 5.- En estos espacios se promoverá el desarrollo de actuaciones de educación ambiental y uso social del medio ambiente. 6.- La declaración de un espacio natural de interés local en terrenos de propiedad privada requerirá la conformidad expresa de las personas propietarias o titulares de un derecho de uso (art. 29). Espacio privado de interés natural. 1.- Son espacios privados de interés natural aquellos terrenos de titularidad privada en los que existan formaciones naturales, especies o hábitats de flora o fauna silvestres cuya protección se considere de interés. 2.- La responsabilidad en la gestión de estos espacios corresponderá a las personas promotoras de su declaración, que deberán ser las propietarias o titulares de un derecho de uso de los terrenos. Podrán suscribirse a su vez acuerdos de cesión total o parcial de su gestión con entidades de custodia del territorio. 3.- Estos espacios no se considerarán incluidos en la Red gallega de espacios protegidos, y su declaración como espacios naturales protegidos no implicará la asignación de recursos de la Comunidad Autónoma de Galicia, aunque podrán tener preferencia en la obtención de ayudas para su conservación y gestión (art. 30).

Las modificaciones no terminan por concretar las características y fines de estos espacios, así como su correlación con la categorías de la IUCN. En el ENIL se siguen restringiendo estos a los municipios, excluyendo otras entidades locales, como las Provincias, con medios, recursos económicos y terrenos que podrían ser incorporados como ENIL. Tanto en los ENIL como en los EPIN no se plantea la necesidad de un técnico competente para la dirección y gestión del espacio, como tampoco se exige para el resto de los espacios, y que como ya hemos indicado puede ser una de las causas del estado anómalo en que se encuentra la gestión de la biodiversidad en Galicia.

Finalmente, el Capítulo VI incluye bajo el epígrafe de "Otras figuras de protección de los espacios" las Áreas Protegidas por Instrumento Internacionales. La normativa estatal (Ley 
42/2007) contempla como tales 7 categorías, mientras que en la gallega se reducen a seis al no considerar, con toda lógica, la as Zonas Especialmente Protegidas de Importancia para el Mediterráneo (ZEPIM), del Convenio para la protección del medio marino y de la región costera del Mediterráneo. El tratamiento de estas categorías en la Ley $5 / 2019$ se reduce a los Humedales de Importancia Internacional, Geoparques, Humedales, Reservas de Biosfera, incorporando junto a una mínima definición derivada de la Ley $42 / 2007$, el proceso para su declaración de una forma excesivamente farragosa y confusa. Estas indicaciones, escritas de forma más conveniente deberían formar parte de una norma de desarrollo, de menor rango, y no incorporarlas en la Ley. Por el contrario, se echa en falta objetivos y orientaciones concretos para implementar estas figuras en el territorio, así como para imbricarlas harmoniosamente con otras figuras de protección y de ordenación territorial.

Dejamos como último punto de esta análisis sobre la Ley 5/2019 un aspecto difícilmente comprensible en un país con una amplía vinculación geográfica, social, económica, social y cultural con el mar, y es el deficiente tratamiento que se realiza en la nueva normativa gallega al medio marino, llegando a excluir de las figuras de "Espacio Natural Protegido", las "Áreas Marinas Protegidas", definidas en la normativa estatal (art. 30 Ley 42/2007), que sorprendentemente el legislador gallego ha tenido a bien no considerar en Galicia. Esta simple consideración permite valorar la Ley 5/2019 como una normativa muy deficiente incapaz de garantizar la conservación y protección de la Biodiversidad y del Patrimonio Natural, y asegurar su uso racional y sostenible.

Agradecimientos A M. López por permitir utilizar su casa de Cedería como refugio para nuestras incursiones por Galicia y facilitarnos numerosas datos y referencias. A los evaluadores anónimos del artículo por sus comentarios y sugerencias.

\section{Bibliografía}

Abel Vilela, F. A. \& Pallín Seco; F. (2010). O urbanismo na Galiza: de onde vimos e cara a onde imos. Cerna. 63: 2021.

ADEGA (2000). 25 anos de medio amb Leiro, A. \& Daporta Padín, X.R. (2003). O medio terrestre. A Nosa Terra. Promocións Culturais Galegas.iente e ecoloxismo na Galiza. ADEGA. 2000. Santiago de Compostela: ADEGA.

Aguirre de Urcola, I. (2017). Paisaxe galega: guía de caracterización e integración paisaxística de valados. Santiago de Compostela: Xunta de Galicia, Consellería de Medio Ambiente e Ordenación do Territorio.

Alvarez-Campana, J.A.; García Arias, A.A.; Santamarina, X. \& García Ares, X. (2004). Bases para a tramitación e xestión ambiental dos parques eólicos de Galicia: 2004. Santiago de Compostela: Consellería de Medio Ambiente, Xunta de Galicia.
Amigo Vázquez, J.; Giménez, J. \& Pulga, I. (2005). Guía da flora do Parque Natural Serra da Enciña da Lastra. Santiago de Compostela: Consellería de Medio Ambiente, Xunta de Galicia.

Bacariza Cortiñas, S. (1994). Concentración parcelaria a xuízo: ¿Progreso rural ou falcatruada ecolóxica?. Cerna: Revista galega de ecoloxía e medio ambiente. 11: 17-18.

Bara Temes, S. (1985). Efectos ecológicos del Eucalyptus globulus en Galicia: estudio comparativo con Pinus pinaster y Quercus robur. Madrid: INIA.

Bermejo Barrera, P. (2002). La contaminación en Galicia. Semata. 13: 167-250.

Bishop, K., Dudley, N., Phillips, A. and Stolton, S. (2004). Speaking a Common Language. The uses and performance of the IUCN System of Management Categories for Protected Areas. Gland, Switzerland: IUCN.

Borrini-Feyerabend, G.N.; Dudley, T.; Jaeger, B.; Lassen, N.; Pathak Broome, A.P. \& Sandwith, T. (2013). Governance of Protected Areas: From understanding to action. Best Practice Protected Area Guidelines Series No. 20, Gland, Switzerland: IUCN.

Bosque Maurel, J. (1984) Del INC al IRYDA: análisis de los resultados de la política de colonización posterior a la Guerra civil ; Agricultura y Sociedad. 32.

Bouhier, A. (1979). La Galice. Essai géographique d'analyse et d'interprétation d'un vieux complexe agraire, 2 Vol. La Roche-sur-Yon: Imprimerie Yonnaise.

Callejo, A. \& Santamarina, J. (2006). Situación del urogallo cantábrico (Tetrao urogallus cantabricus) en la Comunidad Autónoma de Galicia. Robles, L.; Ballesteros, F. \& Canut, J. (2006). El urogallo en España, Andorra y Pirineos Franceses. Situación actual 2005. Madrid: SEO/BirdLife.

Calvelo Pereira, R.; Monterroso Martínez, C. \& Macías Vázquez, F. (2008). El hexaclorociclohexano en Galicia: algunos datos sobre producción, uso y contaminación. Edafología. 15 (1-3): 3-24.

Calzada Pérez, M. \& Alvaro Tordesillas, A. (2008). Pueblos de colonización III. Ebro, Duero, Norte y Levante. Córdoba: Fundación Arquitectura Contemporánea.

Casares Long, J. (2003). Reflexiones sobre el medio ambiente en Galicia. Santiago: Consellería de Medio Ambiente, Centro de Desenvolvemento Sostible, Xunta de Galicia.

Casares Long, J. (2005). Inventario análisis y proyección de las emisiones atmosféricas industriales de Galicia. Santiago de Compostela: Universidad de Santiago de Compostela.

Castroviejo Bolívar, J. (1975). El urogallo "tetrao urogallus L." en España. Madrid: Consejo Superior de Investigaciones Científicas, CSIC.

CBD (1992). Convenio sobre la Diversidad Biológica, Río de Janeiro 5 junio 1992. New York: Naciones Unidas. Tratados Internacionales. Cap. XXVII. Título 8. Medioambiente. 
CDB (2010).Plan Estratégico para la Diversidad Biológica 2011-2020 y las Metas de Aichi para la Diversidad Biológica. Decisión adoptada por la Conferencia de las partes de la Convención sobre la diversidad biológica durante su décima reunión (Nagoya, 18-19 Octubre 2010). Montreal: Secretaría del Convenio sobre la Diversidad Biológica (CDB).

CE (2000). Gestión de espacios Natura 2000: Disposiciones del artículo 6 de la Directiva 92/43/CEE, sobre los hábitats. Bruselas. Nota de la Comisión Europea. 21/11/2018. C(2018). 7621 final. Bruselas: Comisión Europea.

CE (2011). Comunicación de la Comisión al Parlamento Europeo, al Consejo, al Comité Económico y Social Europeo y al Comité de las Regiones: Estrategia de la UE sobre la biodiversidad hasta 2020: nuestro seguro de vida y capital natural [COM(2011) 244 final de 3 de mayo de 2011]. Bruselas: Comisión Europea.

Corbelle Rico, E. \& Rico Boquete, E. (2008). La actividad de las Juntas de Extinción de Animales Dañiños en España, 1944-1968. In: C. González \& E. Nicolás (eds.). Ayeres en discusión: temas clave de Historia Contemporánea. Murcia: Universidad de Murcia.

Cordero Rivera, A.; Martínez Alvarez, A. \& Alvarez Jiménez, M. (2017). Influencia dos monocultivos de eucaliptos nos ecosistemas fluviais. Cerna. 77: 14-17.

Cordero-Rivera, A. (2019). O eucalipto é como o estado: chupa e leva todo para el. Recursos Rurais. 15: 19-33.

Crecente Maseda, J.M., Carballo Neira, M.C.; Santiago Tojo, R., Álvarez Seoane, G. (2016). O turismo na praia das Catedrais. Lugo: Monografías do IBADER.

Crecente Maseda, R. \& Alvarez López, C. (2002). Concentración parcelaria en Galicia. Santiago de Compostela: Xunta de Galicia.

Daporta Padín, X.R. \& Leiro, A. \& (2008). Espazos naturais. Provincia de Pontevedra: Vigo: A Nosa Terra.

Day J.; Dudley, N.; Hockings, M.; Holmes, G.; Laffoley, D.; Stolton, S. \& Wells, S. (2012). Guidelines for Applying the IUCN Protected Area Management Categories to Marine Protected Areas. Gland, Switzerland: IUCN.

Díaz de los Reyes, A. (2015). Cacerías del rey don Alfonso XIII en el Coto de Doñana (1903-1931). Sevilla: Real del Catorce.

Díaz Fierros, F. (2018). Incendios forestales: reflexiones desde Galicia. A Coruña: Hércules Ediciones.

Díaz Fierros, F. (2019). O Antropoceno e a grande aceleración: unha ollada desde Galicia. Santiago de Compostela: Consello da Cultura Galega.

Díaz-Fierros Viqueira, F. (1996). As augas de Galicia. Santiago de Compostela: Consello da Cultura Galega.

Díaz-Fierros Viqueira, F. (2006). A cuestión ambiental en Galicia. Raíces dunga nova cultura. Vigo: Editorial Galaxia.

Díaz-Fierros Viqueira, F. (2006). A cuestión ambiental en Galicia. Raíces dunga nova cultura. Vigo: Editorial Galaxia.
Díaz-Fierros Viqueira, F. (2019). A árbore da discordia. Efectos do eucalipto sobre os recursos hídricos, solos e biodiversidade en Galicia. Recursos Rurais: 15: 9-17.

Díaz-Fierros, F. \& Baamonde, P. (2006). Os incendios forestais en Galicia. Santiago de Cpmpostela: Consello da Cultura Galega.

Díez Ramos, F.J. \& Ramos Medrano, J.A. (2014). Urbanismo, obra pública y medio ambiente. 100 resoluciones judiciales contra la administración pública. Vol. 2. Madrid: Dykinson S.L.

Docampo Barrueco, F. \& Rey Muñíz, X.L. (1996). Espazos naturais de Galicia (2). A Provincia de Pontevedra. A Coruña: Bahia Edicións. Guía da Natureza.

Domínguez Conde, J. (2006). Guía das aves. Complexo Dunar de Corrubedo e Lagoas de Carregal e Vixán: Parque Natural. Santiago de Compostela: Consellería de Medio Ambiente e Desenvolvemento Sostible, Dirección Xeral de Conservación da Natureza. Xunta de Galicia.

Dudley, N.; Shadie, P. \& Stolton, S. (2013) Guidelines for applying protected area management categories. Gland: IUCN: Best Practice Protected Area Guidelines Series. 21.

DXMNAN (2000). D. Rafael Areses Vidal. Biografia dun Home dedicado os Bosques de Galicia. Santiago de Compostela: Direccion Xeral de Montes e Medio Ambiente Natural. Conselleria de Medio Ambiente. Xunta de Galicia.

Eirexas Santamaría, F. (2010). Novos instrumentos para políticas caducas: directrices de ordenamento do territorio. Cerna: 63: 22.

Eirexas Santamaria, F. (2012). Ampliación da Rede Natura 2000: unha proposta do PP trucada, incompleta e incoherente. Cerna. 67: 24-25.

Eirexas Santamaría, F. (2016). A acuicultura industrial en Galiza: o idilio entre a Xunta e a patronal do peixe plano. Cerna. 75: 22-25.

Eirexas Santamaría, F. (2017). As razóns dunha nova lei para salvar os nosos bosques. Cerna 78: 5-6.

Figueras, A. et al. (2005). Las lecciones de la catástrofe del Prestige. Madrid: Biblioteca de Ciencias. CSIC.

Galán Regalado, P.M. (2006). Guía dos anfibios e réptiles: Complexo Dunar de Corrubedo e Lagoas de Carregal e Vixán: Parque Natural. Santiago de Compostela: Consellería de Medio Ambiente e Desenvolvemento Sostible, Dirección Xeral de Conservación da Natureza. Xunta de Galicia.

García Arrese, A.M. (2005). Evaluación de impacto ambiental de parques eólicos en Galicia. Tesis Doctoral. Santiago de Compostela. Universidad de Santiago de Compostela. 
García Arrese, A.M.; Fontán, L. E.; Tapia, L. Nieto, C. \& Macías, F. (2003a). Consideraciones sobre la metodología de los planes de seguimiento y vigilancia ambiental (PSVA) de la avifauna en parques eólicos de Galicia. En: S. González (Coor.) Actas do V Congreso Galego de Ornitología. pp. 21-27. Sociedade Galega de Historia Natural. Santiago de Compostela.

García, A. M.; Fontán, L. E.; Nieto, C. \& Macías, F. (2003b). Avance de resultados de los planes de seguimiento y vigilancia ambiental de avifauna en los parques eólicos de Galicia. En: S. González (Coor.) Actas do V Congreso Galego de Ornitología. pp. 29-32. Sociedade Galega de Historia Natural. Santiago de Compostela.

Giménez, C. \& Sánchez, L. (1994). Historia y evolución de la colonización agraria en España. Vol. 4. Políticas Unidad y diversidad en la colonización agraria: perspectiva comparada del desarrollo de las zonas regables. Madrid: MAPA, MAP, MOPU.

Gómez Orea, D. \& Gómez Villarino, M.T. (2013). Evaluación de impacto ambiental (2nd edición). Madrid: Mundi Prensa.

González Laxe, F. (2003). El impacto del Prestige. Análisis y evaluación de los daños causados por el accidente del Prestige y dispositivos para la regeneración medioambiental y recuperación económica de Galicia. A Coruña: Fundación Pedro Barrie de la Maza.

González Prieto, S. \& Vilariño Gómez, A. (1997). Espazos naturais de Galicia (3). A Provincia de Ourense. A Coruña: Bahia Edicións. Guía da Natureza.

González Prieto, S.J. (2013). Corcoesto: moito arsénico. Cerna 69: 15.

González Prieto, S.J. (2019). Efectos dos eucaliptos sobre os ecosistemas ibéricos. Unha revisión. Recursos Rurais. 15: $43-55$

González Sánchez, F. \& Purroy, J. (2012). Cuenta atrás para salvar al Urogallo cantábrico. Aves y naturaleza. 10: 20-21

Greenpeace (2001). Destrucción a toda costa, 2001. Madrid: Greenpeace España.

Greenpeace (2002). Destrucción a toda costa, 2002. Informe sobre el estado del litoral español. Incluye un detallado análisis por Comunidades Autónomas en el que se resaltan las principales amenazas que se ciernen sobre nuestras costas. Madrid: Greenpeace España.

Greenpeace (2003). Destrucción a toda costa, 2003. Informe sobre el estado del litoral español. Incluye un detallado análisis por Comunidades Autónomas en el que se resaltan las principales amenazas que se ciernen sobre nuestras costas. Madrid: Greenpeace España.

Greenpeace (2004). Destrucción a toda costa, 2004. Informe sobre el estado del litoral español. Incluye un detallado análisis por Comunidades Autónomas en el que se resaltan las principales amenazas que se ciernen sobre nuestras costas. Madrid: Greenpeace España.
Greenpeace (2005). Destrucción a toda costa, 2005. Informe sobre el estado del litoral español. Incluye un detallado análisis por Comunidades Autónomas en el que se resaltan las principales amenazas que se ciernen sobre nuestras costas. Madrid: Greenpeace España.

Greenpeace (2006). Destrucción a toda costa, 2007. Informe de sobre la situación del litoral español. Madrid: Greenpeace España.

Greenpeace (2007). Destrucción a toda costa, 2007. Informe de sobre la situación del litoral español. Madrid: Greenpeace España.

Greenpeace (2008). Destrucción a toda costa, 2008. Informe de sobre la situación del litoral español. Madrid: Greenpeace España.

Greenpeace (2009). Destrucción a toda costa, 2009. Informe de Greenpeace sobre el estado del litoral español. y sus espacios protegidos. Madrid: Greenpeace España.

Greenpeace (2010). Destrucción a toda costa, 2010. Informe de Greenpeace sobre el estado del litoral español. Madrid: Greenpeace España.

Greenpeace (2011). Destrucción a toda costa 2012. Un análisis de la situación de los puertos del Estado. Madrid: Greenpeace España.

Greenpeace (2012). Destrucción a toda costa 2012. Informe sobre la situación económica ambiental del litoral español. Madrid: Greenpeace España.

Greenpeace (2013). Destrucción a toda costa 2013. Análisis del litoral a escala municipal. Madrid: Greenpeace España.

Greenpeace (2017). Protección a toda costa 2017. Un tesoro que no debemos perder. Madrid: Greenpeace España.

Greenpeace (2018). A toda costa 2018. Análisis de la evolución y estado de conservación de los bienes y servicios que proporcionan las costas. Madrid: Greenpeace España.

Greenpeace (2018). A toda costa 2019. Análisis de los ecosistemas naturales costeros vulnerables a la urbanización masiva del litoral. Madrid: Greenpeace España.

Guitián Rivera, L. (2002), Destrucción del bosque en Galicia. Semata 13: 105-166.

Gutiérrez, F. (2011). A explotación da pizarra en Galiza e os seus impactos ambientais. Cerna 65: 36-37.

Hernández Pacheco, E. (1933). La comisaría de parques nacionales y la protección a la naturaleza en España. Madrid: Ministerio de Agricultura,

Iglesias Iglesias, L. (1929). El Parque Regional Gallego. Madrid. Junta de Misiones Culturales en Galicia.

IUCN \& WCMC. (1994). Guidelines for Protected Area Management Categories. Gland, Switzerland: IUCN

Izco, J. (1994). Os bosques Atlánticos europeos. A Coruña: Bahía Ediciones. 
Izco, J.; Amigo, J.; Ramil-Rego, P. \& Díaz, R.; Sánchez, J.M. (2006). Brezales: biodiversidad, usos y conservación. Recursos Rurais. 2: 5-24.

Kothari, A.; Corrigan, C.; Jonas, H.; Neumann, A. \& Shrumm, H. (2012). Recognising and Supporting Territories and Areas Conserved By Indigenous Peoples and Local Communities: Global Overview and National Case Studies. Technical Series no. 64. Montreal, Canada: Secretariat of the Convention on Biological Diversity.

Laguna Lumbreras, E. (1990). Flora de la Comunidad Valenciana: microrreservas de flora. Valencia: Generalitat Valenciana. Consellería de Medio Ambiente.

Laguna Lumbreras, E. (2001). The micro-reserves as a tool for conservation of threatened plants in Europe. Nature and Environment, 121. Strasbourg: Council of Europe.

Layna, J.F. (2007). Galicia pierde sus urogallos. Quercus. 257: $80-81$

Leiro, A. \& Daporta Padín, X.R. (2007a). Espazos naturais. Provincia de Lugo: Vigo: A Nosa Terra.

Leiro, A. \& Daporta Padín, X.R. (2007b). Espazos naturais. Provincia de Ourense: Vigo: A Nosa Terra.

Leiro, A. \& Daporta Padín, X.R. (2008a). Galicia: O mar. Vigo: A Nosa Terra. Promocións Culturais Galegas.

Leiro, A. \& Daporta Padín, X.R. (2008b). O medio terrestre. Vigo: A Nosa Terra. Promocións Culturais Galegas.

Leiro, A. (2005). Galiza. A natureza. Vigo: A Nosa Terra. Promocións Culturais Galegas.

Leiro, A. (2006). As montañas de Galiza. Vigo: A Nosa Terra. Promocións Culturais Galegas.

Leiro, A. (2007). A costa de Galiza. Vigo: A Nosa Terra. Promocións Culturais Galegas.

Leiro, A.; Daporta Padín, X.R. \& Caamaño Rivas, V. (2003). Espazos naturais. Provincia de Pontevedra: Vigo: A Nosa Terra.

Leiro, A.; Daporta Padín, X.R. \& Caamaño Rivas, Victor, (2003). Espazos naturais. Vigo: A Nosa Terra. Promocións Culturais Galegas.

Leiro, A.; Daporta Padín, X.R. \& Núñez Pérez, M. (2007). Os rios de Galiza

López Fernández, A.; Covelo, P. \& Martínez, J.A. (2015). Asistencia e estudo dos réptiles e mamíferos mariños en Galicia: caderno de campo. Santiago de Compostela: Dirección Xeral de Conservación da Natureza, Consellería de Medio Ambiente, Territorio e Infraestructuras, Xunta de Galicia.

López Ramón, F. \& López Ramón, F. (1980). La conservación de la naturaleza: los espacios naturales protegidos. Bolonia: Publicaciones del Real Colegio de España. Volumen 44 de Studia Albornotiana.

López Vispo, D. (2010a). A entrega oficial do territorio á especulación: modificación da Lei do solo. Cerna 61: 1213
López Vispo, D. (2010b). O Plan Sectorial de Ordenación do Litoral, unha aproximación ambiental. Cerna. 61: 15.

López Vispo, D. (2010c). Unha historia de agresións que debe rematar: Galiza e o seu territorio. Cerna. 63: 16-19.

López Vispo, D. (2018). O caos de Barreiros: visto para sentenza. Cerna. 79: 30-31.

Louzao, X. \& Eirexas Santamaría, F. (2018). A mina de Touro-O Pino, de macrovertedoiro a megaexplotación mineira. Cerna. 79: 20-23.

Maceiras, M. (2012). Monte Pindo, parque natural!. Cerna. 67: $22-23$

Macías Vázquez, F. \& Calvo de Anta, F. (1999). Parque eólico Montouto. Plan de Recuperación de suelos y vegetación. Santiago de Compostela: Universidade de Santiago. Departamento de Edafoloxía. [Informe no accesible. Citado por García Arese, 2005].

Macías Vázquez, F. \& Nieto, C. (2002). Informe complementario sobre los puntos de interés geológico del parque eólico Terral. Santiago de Compostela: Universidade de Santiago: Laboratorio de Tecnología Ambiental del Instituto de Investigaciones Tecnológicas. [Informe no accesible. Citado por García Arese, 2005].

Macías Vázquez, F. et al. (1998). Estudio de las formaciones edáficas afectadas por el parque eólico Montouto, con particular atención a las áreas de turbera. Universidade de Santiago. Departamento de Edafoloxía. [Informe accesible. Citado por García Arese, 2005].

Macías Vázquez, F.; Quintas Mosteiro, Y. \& García Arrese; A.M. (1999b). Estudio de las formaciones vegetales y flora en las áreas de afección de los aerogeneradores del parque eólico Carba. Santiago de Comopostela: Universidade de Santiago: Laboratorio de Tecnología Ambiental del Instituto de Investigaciones Tecnológicas. [Informe no accesible. Citado por García Arese, 2005].

Macías Vázquez, F.; Y. Quintas Mosteiro y A.M. García Arrese (1999a). Estudio de las formaciones vegetales y flora en las áreas de afección de los aerogeneradores del parque eólico Villalba. Santiago de Comopostela: Universidade de Santiago: Laboratorio de Tecnología Ambiental del Instituto de Investigaciones Tecnológicas. [Informe no accesible. Citado por García Arese, 2005].

Mangas Navas, J.M. \& Barciela López, C. (1990). Historia y evolución de la colonización agraria en España. Vol. 2. Políticas administrativa y económica de la colonización agraria: análisis institucional y financiero (1936-1977). Madrid: MAPA, MAP, MOPU.

Martín Palmero, F.; González Laxe, F.; Pose, J.; Menéndez Pérez, E. \& Dopico Castro, J. (2004). Desarrollo sostenible y huella ecológica. Una aplicación a la economía gallega. A Coruña: Netbiblo.

Martínez Carneiro, X.L. (1997). Antela: A memoria asolagada. Vigo: Edicións Xerais.

Martinez Roperio, V. (2005). A paisaxe. Vigo: A Nosa Terra. Promocións Culturais Galegas 
MEL (1993). Concentraçons parcelarias, desertizaçom asegurada. Cerna: Revista galega de ecoloxía e medio ambiente. 6: 28-29.

MEL (1994). A Outra maneira de fazer concentraçons parcelarias. Cerna: Revista galega de ecoloxía e medio ambiente. 11: 14-16

Miranda, D. \& Álvarez-López, C. \& Crecente Maseda, R. (1999). Galicia: La concentración parcelaria en Galicia. Agricultura: Revista agropecuaria. 68 (810): 1108-1111.

Monclús, F.J. \& Pyón, J.L. (1988). Historia y evolución de la colonización agraria en España. Vol. 1. Políticas y técnicas en la ordenación del espacio rural. Madrid: MAPA, MAP, MOPU.

Muñiz, X.A. (2012). Humidal da Frouxeira: vítima da neglixencia da Administración. Cerna 67: 19-21

Muñiz, X.A. (2016). A Lagoa da Frouxeira: recesión histórica dun humidal en proceso de destrucción. Cerna. 76: 14-17.

Murado, M.A. (2008). Otra idea de Galicia. Barcelona: Editorial Debate.

Nicolás López, N. (2019). El urogallo cantábrico se sitúa a las puertas de la extinción. Quercus. 397: 34-35

Novoa, F.; Baselga, A. Gañán, I.; González, X.M. \& Eiroa, L. (2009). Guía de los coleópteros. Complexo Dunar de Corrubedo e Lagoas de Carregal e Vixán: Parque Natural. Santiago de Compostela: Consellería de Medio Ambiente e Desenvolvemento Sostible, Dirección Xeral de Conservación da Natureza. Xunta de Galicia.

Obeso Suárez, J.R. \& Bañuelos Martínez, M.J. (2003). El urogallo (Tetrao urogallus cantabricus) en la Cordillera Cantábrica. Madrid: Organismo Autónomo Parques Nacionales.

ONU (2015). Transformar nuestro mundo: la Agenda 2030 para el Desarrollo Sostenible. New York: Naciones Unidas. Asamblea General.

ONU (2019). Informe de los Objetivos de Desarrollo Sostenible 2019. New York: Naciones Unidas.

Otero Pedrayo, R. (1945). Guía de Galicia. Santiago: Sucesores de Galí.

Pallín Seco, F. (2010). Barreiros, á "costa" de todos. Cerna: 61: 14

Prada, A. \& Vázquez, M.X. (2004). Economic, social and environmental effects of the "Prestige" oil spill. Santiago de Compostela: Consello da Cultura Galega.

Pulgar Sañudo, I. (2004). Guía de la flora del Parque Natural Montes de Invernadeiro. Santiago: Dirección Xeral de Conservación da Natureza. Xunta de Galicia.

Purroy, F.J. (1998). El otoño del urogallo cantábrico. Biológica: conocer y conservar la naturaleza. 19: 26-32.

Ramil-Rego, P. \& Crecente Maseda, R. (2012). Plan Director da Rede Natura 2000 de Galicia. Documento Técnico. Santiago: Xeral de Conservación da Natureza. Xunta de Galicia.
Ramil-Rego, P. \& Domínguez Conde, J. (2006). A Lagoa de Cospeito. Santiago: Xunta de Galicia.

Ramil-Rego, P. \& Izco, J. (2003). Inventario dos Humidais de Galicia. Memoria Técnica. Dirección Xeral de Conservación da Natureza, Conselleria de Medio Ambiente (Xunta de Galicia) \& Laboratorio de Botánica e Bioxeografía (Universidade de Santiago). Santiago de Compostela.

Ramil-Rego, P. et al. (2008). Os Hábitats de Interese Comunitario en Galicia. Tomo 1.- Descrición e Valoración Territorial. Tomo 2.- Fichas Descriptivas. Monografías do Ibader. Universidade de Santiago de Compostela. Lugo.

Ramil-Rego, P., Vales, C. (2019). Especies Exóticas Invasoras: situación e propostas de mitigación. Lugo: IBADER: Monografías do Ibader.

Ramil-Rego, P.; Ferreiro da Costa, J.; Gómez-Orellana, L.; Rodríguez Guitián, M. (2017b). Humidais de Galicia: Inventario e valoración ambiental no periodo 2001-2016. Ramil-Rego, R.; Gómez-Orellana, L \& Ferreiro da Costa, J. (Eds). Conservación e xestión de humidais en Galicia. Lugo: IBADER. Monografía.

Ramil-Rego, P.; Gómez-Orellana, L. \& Ferreiro da Costa, L. (2017a). Conservación e Xestión de Humidais en Galicia. Lugo: IBADER. Monografías do Ibader.

Ramil-Rego, P.; Rodríguez Guitián, M.A.; Gómez-Orellana, L \& Ferreiro da Costa, J. (2005). Reseña del Patrimonio Natural y la Biodiversidad de Galicia: año 2005. Monografías do IBADER - Serie Biodiversidade. Universidade de Santiago de Compostela. Lugo.

Ramil-Rego, P.; Rodríguez Guitián, M.A.; Gómez-Orellana, L \& Ferreiro da Costa, J. (2008). Reseña do Patrimonio Natural e a Biodiversidade de Galicia: año 2008. Monografías do IBADER - Serie Biodiversidade. Universidade de Santiago de Compostela. Lugo

Ramil-Rego, P.; Rodríguez Guitián, M.A.; Gómez-Orellana, L \& Ferreiro da Costa, J. (2012). Reseña do Patrimonio Natural e a Biodiversidade de Galicia: año 2012. Monografías do IBADER. Universidade de Santiago de Compostela. Lugo.

RCS (1971). Convención relativa a los humedales de Importancia Internacional. Especialmente como hábitats de aves acuáticas. Hecho en Ramsar (Irán), 02/02/1971. Modificado según el protocolo de París 3/12/1982 y las Enmiendas de Regina 28/05/1987. Gland (Switzerland): Ramsar Convention Secretariat.

Regeuiro Ferreira, R.M. (2011). O desenvolvemento eólico en Galiza (1995-2010): trazos diferenciadores. Cerna 65: 12-13.

Regos, A.; Gil, A.; Domínguez, J. \& Pardavilla, X. (2012). Atlas de los vertebrados terrestres reproductores en el Parque Natural Baixa Limia-Serra do Xurés y ZEPVN-LIC Baixa Limia. Santiago de Compostela: D 
Reza Rodríguez, X.B. (2006). Os Parques Naturais de Galicia. Santiago de Compostela: Consellería de Medio Ambiente e Desenvolvemento Sostenible. Xunta de Galicia.

Rodríguez Brea, F. (1993). Guía do parque natural do complexo dunar de Corrubedo e lágoas de Carregal e Vixán. A Coruña: Consellería de Agricultura, Gandería e Montes, Dirección Xeral de Montes e Medio Ambiente Natural, Servicio de Medio Ambiente Natural da Coruña.

Rodríguez Gonzalez, X.A. (1992). La Industria de la Pizarra. Colección de Estudios Económicos del Centro de Predicción Económica de Galicia. Santiago de Compostela: Diaz de Santos.

Rodríguez, B. (2011). As rías galegas non valen para o cultivo intensivo do salmón atlántico": Alberto de Coo é biólogo mariño e experto en avaliación de riscos ambientais. Cerna. 65: 10-11.

Rodríguez, B. (2013). A nova era da minaría metálica en Galiza. Cerna 69: 10-12.

Romaní Barrientos, R.G. \& Chantada Acosta, J.R. (1996). Medio ambiente y desarrollo. Santiago de Compostela: Universidade de Santiago de Compostela.

Ruiz de Larramendi, A. (1992). Espacios naturales protegidos de España. Madrid: INCAFO.

Salvadores Ramos, R.; Arcos Fernández, F.; Sierra Abraín, F.; Mouriño Lourido, J.; Alonso Iglesias, P.; Otero Pérez, X.L. (2004). Los espacios naturales de Galicia. Vigo: Edicións Nigra Trea.

Sanz Larruga, F.J. \& Fernández Carballal, A. (2019). Derecho urbanístico de Galicia: en homenaje al Profesor José Luis Meilán Gil. Valencia: Tirant lo Blanch,

Sanz Larruga, F.J. (1997). Derecho ambiental de Galicia. Santiago de Compostela: Fundación Caixa Galicia

Sauquillo Balbuena, E. (2011). Guía das orquídeas. Complexo Dunar de Corrubedo e Lagoas de Carregal e Vixán: Parque Natural. Santiago de Compostela: Consellería de Medio Ambiente e Desenvolvemento Sostible, Dirección Xeral de Conservación da Natureza. Xunta de Galicia.

SGHN (1993). A Concentración parcelaria da Xunta é un fraude. Cerna: Revista galega de ecoloxía e medio ambiente. 9: 38-39.

Sobrado Correa, H. (2003). "Los enemigos del campesino": la lucha contra el lobo y otras "alimañas" nocivas para la agricultura en la Galicia de la Edad Moderna. Obradoiro de historia moderna. 12: 105-140.

Stolton, S. \& Dudley, N. (2010). Arguments for Protected Areas: Multiple Benefits for Conservation and Use. London: Earthscan.

Tapia, L.; Fontán, L.; García-Arrese, A.; Nieto, C. \& Macias, F. (2005). Metodología para la evaluación de los efectos sinérgicos generados por parques eólicos sobre la avifauna: un caso práctico en el lic "serra do xistral" (galicia; noroeste de españa). Ecología, 19: 301-312
Turgalicia (2001). Galicia. Santiago de Compostela: Dirección Xeral de Turismo. Xunta de Galicia.

Turgalicia (2004). Galicia: Costa da Morte, un mar de vida. Santiago de Compostela: Turgalicia. Xunta de Galicia.

Turgalicia (2008). El Camino de Santiago. Galicia: Pórtico de la Gloria. Santiago de Compostela: Dirección Xeral de Turismo, Consellería de Cultura, Comunicación Social e Turismo, Xunta de Galicia.

Turgalicia (2008). Galicia: a mariña lucense. Turgalicia. Xunta de Galicia.

Turgalicia (2010). Galicia al natural. Santiago de Compostela: Turgalicia. Xunta de Galicia

Turgalicia (2013). Bosques de Galicia. Santiago de Compostela: Turgalicia. Xunta de Galicia

Turgalicia (2016). Rutas ornitológicas. Galicia Birding. Santiago de Compostela: Turgalicia. Xunta de Galicia

Turgalicia (2017). Parques Naturales de Galicia. Santiago de Compostela: Turgalicia. Xunta de Galicia

Ugarte Otero, X. (2007). Imagen y posicionamiento de Galicia como destino turístico a nivel nacional e internacional. Santiago de Compostela: Universidade de Santiago de Compostela

Urgorri, V. (2010). Efectos do Prestige sobre os ecosistemas: unha avaliación oito anos despois. Cerna 62: 26-28.

Vales Vázquez, C. (1994). As concentracións parcelarias unha arma de destrucción. Cerna: Revista galega de ecoloxía e medio ambiente. 11: 12-13

Varela Díaz, R. (2010). Grandes contaminantes industriais en Galiza: segundo o rexistro PRTR-España. Cerna 61: 18-21

Varela Díaz, R. (2017). Incendios e eucaliptos avanzan xuntos. Cerna 78: 10-13

Varillas, B. (2014). Parques Nacionales de España. Madrid: Editorial Lunwerg

Vázquez, M. (2010). O Eume, 50 anos de secuestro. Cerna 61: 40 .

Villanueva Paredes, A. \& Leal Maldonado, J. (1990). Historia y evolución de la colonización agraria en España. Vol. 3. La planificación del regadío y los pueblos de colonización. Madrid: MAPA, MAP, MOPU.

VVAA (1978). Estudio preliminar sobre posibles zonas protegidas de Galicia. Departamento de Edafología y sección de avifauna de la Universidad de Santiago BRAÑA 2 (1): 124-129.

VVAA (1995). Espacios naturais de Galicia (1). A provincia de A Coruña. A Coruña: Bahia Edicións. Guía da natureza.

VVAA (1998). Espazos naturais de Galicia (4). A Provincia de Lugo. A Coruña: Bahia Edicións. Guía da Natureza.

VVAA (2004), La red de Parques Nacionales de España. Madrid: Red de Parques Nacionales de España. OAPN. 


\section{Normativas y sentencias indicadas en el texto}

Ley 37/1966, de 31 de mayo, sobre creación de Reservas Nacionales de Caza. BOE 131, 02/06/1966.

Anuncio de 21/12/2011, de la Dirección General de Conservación de la Naturaleza, por el que se acuerda someter a participación del público la propuesta de ampliación de la Red Natura 2000 de Galicia. DOG 1, 2/01/2012.

CE (1978). Constitución Española. BOE 311. 29/12/1978.

Decreto 110/2004, de 27 de mayo, por el que se regulan los humedales protegidos. DOG 108, 07/06/2004.

Decreto $127 / 2008$, de 5 de junio, por el que se desarrolla el régimen jurídico de los humedales protegidos y se crea el Inventario de humedales de Galicia. DOG 122, 25/06/2008.

Decreto 139/1992, de 5 de junio, por el que se declara Parque Natural el complejo dunar de Corrubedo y lagunas de Carregal y Vixán (ayuntamiento de Ribeira - A Coruña). DOG 113, 15/06/1992.

Decreto 148/1992, de 5 de junio, por el que se aprueba el Plan de Ordenación de los Recursos Naturales del Complejo Dunar dé Corrubedo y Lagunas de Carregal y Vixán (ayuntamiento de Ribeira - A Coruña). DOG 114. 16/06/1992.

Decreto 148/2007, do 19 de julio, por el que se determina la creación, composición y funcionamiento del Consejo de la Red de Parques Naturales de Galicia. DOG 149. 02/08/2007.

Decreto 155/1997, de 5 de junio, por el que se declara el Parque Natural de O Invernadeiro. DOG 123, 27/06/1997.

Decreto 157/2002, de 4 de abril, por el que se declara el Parque Natural de la Serra da Enciña da Lastra. DOG. 85, 03/05/2002.

Decreto 177/2018, de 27 de diciembre, por el que se aprueba el Plan rector de uso y gestión del Parque Nacional Marítimo-Terrestre de las Islas Atlánticas de Galicia. DOG 34, 18/02/2018

Decreto 218/1994, de 17 de octubre, del Gobierno Valenciano. DOGV 2379, 3/11/1994

Decreto 218/1997, de 30 de julio, por el que se declara el Parque Natural de las Fragas do Eume. DOG 153, 11/08/1997.

Decreto 37/2014, de 27 de marzo, por el que se declaran zonas especiales de conservación los lugares de importancia comunitaria de Galicia y se aprueba el Plan director de la Red Natura 2000 de Galicia. DOG 62, $31 / 03 / 2014$

Decreto $37 / 2014$, de 27 de marzo, por el que se declaran zonas especiales de conservación los lugares de importancia comunitaria de Galicia y se aprueba el Plan director de la Red Natura 2000 de Galicia. DOG 62, $31 / 03 / 2014$.
Decreto 401/2009, de 22 de octubre, por el que se declara el ámbito territorial del Parque Natural de la Baixa LimiaSerra do Xurés. DOG 212, 29/10/2009.

Decreto 63/2007, de 14 de junio, por el que se crean el Catálogo de Flora Protegida de Castilla y León y la figura de protección denominada Microrreserva de Flora. BCL 119, 20/06/2007.

Decreto 69/2016, de 19 de mayo, por el que se crea la Red de Parques Naturales de Galicia. DOG 116, 21/06/2016.

Decreto $80 / 2015$, de 11 de junio, por el que se aprueba el Plan de conservación del monumento natural de la Playa de las Catedrales. DOG 110, 12/06/2015

Decreto 82/1989, de 11 de mayo, por el que se regula la figura del espacio natural en régimen de protección general. DOG. 104, 1/06/1989.

Decreto 88/2007 del 19 de abril, por el que se regula el Catálogo gallego de especies amenazadas. DOG 155, 9/05/2007.

Decreto-ley 17/1971, de 28 de octubre, por el que se modifica la Administración Institucional del Ministerio de Agricultura y se encomienda al Gobierno la reestructuración de dicho Departamento. BOE 264, 4/11/1971.

Directiva 2001/42/CE del Parlamento Europeo y del Consejo, de 27 de junio de 2001, relativa a la evaluación de los efectos de determinados planes y programas en el medio ambiente. DOUE 197, 21/7/2001.

Directiva 2009/147/CE del Parlamento Europeo y del Consejo, de 30 de noviembre de 2009, relativa a la conservación de las aves silvestres. DOUE 20, 26/01/2010.

Directiva 2011/92/UE del Parlamento Europeo y del Consejo de 13 de diciembre de 2011 relativa a la evaluación de las repercusiones de determinados proyectos públicos y privados sobre el medio ambiente. DOUE 26, 28/01/2012.

Directiva 79/409/CEE del Consejo, de 2 de abril de 1979, relativa a la conservación de las aves silvestre. DOCE 103, 25/04/1979.

Directiva 92/43/CEE del Consejo, de 21 de mayo de 1992, relativa a la conservación de los hábitats naturales y de la fauna y flora silvestres. DOCE 206, 22/07/1992.

Directiva 97/62/CE del Consejo de 27 de octubre de 1997 por la que se adapta al progreso científico y técnico la Directiva 92/43/CEE, relativa a la conservación de los hábitats naturales y de fauna y flora silvestres. DOCE 305 , 08/11/1997.

Instrumento de adhesión de España de 18/03/1982 al Convenio relativo a Humedales de importancia internacional, especialmente como hábitat de aves acuáticas, hecho en Ramsar el 2 de febrero de 1971. BOE. 199, 20/08/1982.

Ley $1 / 1983$, de 22 de febrero, reguladora de la Xunta y su Presidente. DOG 23, 21/03/1983. 
Ley 11/1994, de 27 de diciembre, de la Generalitat Valenciana, de Espacios Naturales Protegidos de la Comunidad Valenciana. DOGV 2423, 09/01/1995.

Ley $15 / 2002$, de 1 de julio, por la que se declara el Parque Nacional marítimo-terrestre de las Islas Atlánticas de Galicia. BOE 157, 2/07/2002.

Ley $2 / 2018$, de 15 de marzo, por la que se modifican la Ley 3/2015, de 5 de marzo, de Caza de Castilla-La Mancha y otras normas en materia medioambiental y fiscal. DOCM $60,26 / 03 / 2018$.

Ley 22/1988, de 28 de julio, de Costas. BOE 181, de 29/07/1988.

Ley 37/1966, de 31 de mayo, sobre creación de Reservas Nacionales de Caza. BOE 131, 2/06/1966.

Ley 4/1989, de 27 de marzo, de Conservación de los Espacios Naturales y de la Flora y Fauna Silvestres. BOE $74,28 / 03 / 1989$

Ley 4/2015, de 24 de marzo, del Patrimonio Natural de Castilla y León. BOCL 61, 30/03/2015.

Ley $5 / 2019$, de 2 de agosto, del patrimonio natural y de la biodiversidad de Galicia. BOE 229, 24/09/2019. DOG 149, 7/08/2019.

Ley $5 / 2019$, de 2 de agosto, del patrimonio natural y de la biodiversidad de Galicia. BOE 229, 24/09/2019. (DOG 149, 07/08/2019). DOG 1007, 05/06/1998.

Ley 9/1999, de 26 de mayo, de Conservación de la Naturaleza. DOCM 40, 12/06/1999.

Ley 9/2001, de 21 de agosto, de Conservación de la Naturaleza. BOE 230, 25/09/2001. (DOG 171, 04/09/2001).

Ley 91/1978, de 28 de diciembre del Parque Nacional de Doñana. BOE 11, de 12/01/1979.

Ley de 24/07/1918, relativa a desecación de lagunas, marismas y terrenos pantanosos. Gaceta de Madrid 208, 27/07/1918.

Ley de 7 de diciembre de 1916, de Parques Nacionales de España. Gaceta de Madrid. 343, 8/12/1916.

Ley Orgánica 1/1981, de 6 de abril, de Estatuto de Autonomía para Galicia. BOE 101. 18/05/1981.

Ley Orgánica 10/1985, de 2 de agosto, de Autorización para la Adhesión de España a las Comunidades Europeas. BOE 189. 8/08/1985.

Ley Orgánica 10/1995, de 23 de noviembre, del Código Penal. BOE 281, 24/11/1995.

Orden 05/07/1935, del Ministerio de Agricultura, declarando sitio natural de interés nacional una parte del monte público de Alhoya, del Ayuntamiento de Túy, en la provincia de Pontevedra. Gaceta de Madrid, 194, 13/07/1935.

Orden 14/02/2001 por la que se inicia el procedimiento para la elaboración del Plan de Ordenación de Recursos Naturales de Ancares-Courel. DOG 37, 21/02/2001.
Orden 14/5/1991 de 14 de mayo. Normas complementarias y subsidiarias de planeamiento de La Coruña, Lugo, Ourense y Pontevedra. DOG 19/06/1991; 20/06/1991, 11/07/1991, 12/07/1991, 15/07/1991, 16/07/1991

Orden 28/05/1998 por la que se prorroga la inclusión del río Sor en el Registro General de Espacios Naturales de Galicia

Orden 31/10/1993, del Ministerio de Agricultura por la que se declaran como Sitios de Interés Nacional distintos parajes de Galicia: "La cumbre de la Curotiña de la Sierra del Barbanza. El promontorio del Cabo Vilano, y el islote situado en su extremo inmediato. La parte culminante del promontorio del Cabo de Vares". Gaceta de Madrid 309, 05/11/1933.

Real Decreto 1055/1995, de 23 de junio, por el que se modifica parcialmente la estructura orgánica básica del Ministerio de Agricultura, Pesca y Alimentación. BOE. 158, 4/07/1995.

Real Decreto 1193/1998, de 12 de junio, por el que se modifica el Real Decreto 1997/1995, de 7 de diciembre, por el que se establecen medidas para contribuir a garantizar la biodiversidad mediante la conservación de los hábitats naturales y de la fauna y flora silvestres. BOE 151, 25/06/1998.

Real Decreto 139/2011, de 4 de febrero, para el desarrollo del Listado de Especies Silvestres en Régimen de Protección Especial y del Catálogo Español de Especies Amenazadas. BOE 43, 26/02/2011.

Real Decreto 1421/2006, de 1 de diciembre, por el que se modifica el Real Decreto 1997/1995, de 7 de diciembre, por el que se establecen medidas para contribuir a garantizar la biodiversidad mediante la conservación de los hábitats naturales y de la flora y fauna silvestres. BOE 288, 2/12/2006.

Real Decreto 1628/2011, de 14 de noviembre, por el que se regula el listado y catálogo español de especies exóticas invasoras. BOE 298, 12/12/2011.

Real Decreto 1997/1995, de 7 de diciembre, por el que se establecen medidas para contribuir a garantizar la biodiversidad mediante la conservación de los hábitats naturales y de la fauna y flora silvestres. BOE 310 , 28/12/1995.

Real Decreto 23/02/1917, disponiendo que por los Ingenieros Jefes de los distritos forestales se remita a la Dirección General de Agricultura, Minas y Montes, en el plazo de dos meses, una relación de los sitios más notables de sus respectivas demarcaciones que por reunir las condiciones que se indican merezcan una especial protección. Gaceta de Madrid 55, 24/02/1917.

Real Decreto 2497/1980, de 17 de octubre, sobre declaración del Parque Natural de las Islas Cíes (Pontevedra). BOE 275, 15/11/1980.

Real Decreto 3160/1978, de 4 de diciembre, sobre declaración del Parque Natural del monte Alhoya (Pontevedra). BOE 16, 18/01/1978. 
Real Decreto 435/2004, de 12 de marzo, por el que se regula el Inventario nacional de zonas húmedas. BOE 73 , 25/03/2004

Real Decreto 439/1990, de 30 de marzo, por el que se regula el Catálogo Nacional de Especies Amenazadas. BOE 82, 5/04/1990.

Real Decreto 556/2011, de 20 de abril, para el desarrollo del Inventario Español del Patrimonio Natural y la Biodiversidad. BOE 112, 11/05/2011

Real Decreto 630/2013, de 2 de agosto, por el que se regula el Catálogo español de especies exóticas invasoras. BOE 185. 3/08/2013.

Real Orden relativa a la declaración de Sitios de interés nacional y de Monumentos naturales de interés nacional. Gaceta de Madrid 203, 22/07/1927.

Resolución 17/02/2017, de la Secretaría de Estado de Medio Ambiente, por la que se establecen tres listas patrón: la de las especies terrestres, la de las especies marinas y la de los hábitats terrestres, presentes en España. BOE 55, 6/03/2017.

Resolución 22/03/2013, de la Dirección General de Sostenibilidad de la Costa y del Mar, por la que se establecen los dos primeros elementos del Inventario Español de Hábitats Marinos: la lista patrón de los tipos de hábitats marinos presentes en España y su clasificación jerárquica. BOE 88, 12/04/2013.

Sentencia 101/2005, 20/04/2005. Conflicto positivo de competencia 2287-2000. Planteado por el Consejo de Gobierno de la Junta de Andalucía en relación con el Real Decreto 1803/1999, por el que se aprueba el Plan director de la red de parques nacionales. Competencias sobre medio ambiente y espacios naturales protegidos: parques nacionales (STC 194/2004). Delimitación de preceptos estatales. Voto particular. BOE 120, 20/05/2005.

Sentencia 102/1995, de 26/06/1995. Recursos de inconstitucionalidad 1.220/1989, 1.232/1989, 1.238/1989, $1.239 / 1989,1.260 / 1989$ y $1.268 / 1989$ (acumulados); conflictos positivos de competencia 95/1990, 163/1990, 170/1990, 172/1990 y 209/1990 (acumulados); y conflictos positivos de competencia 162/1990, 210/1990 y 1.938/1990 (acumulados). Promovidos, respectivamente, los recursos de inconstitucionalidad, por el Gobierno Vasco, la Junta de Andalucía, el Gobierno de Canarias, la Generalidad de Cataluña, la Junta de Galicia y el Parlamento de Cataluña contra la Ley 4/1989, de 27 de marzo, de Conservación de los Espacios Naturales y de la Flora y Fauna Silvestres; los conflictos positivos de competencia 95/1990, 163/1990, 170/1990, 172/1990 у 209/1990 por la Comunidad Autónoma de Castilla y León, el Gobierno Vasco, el Consejo de Gobierno de la Diputación General de Aragón, el Consejo Ejecutivo de la Generalidad de Cataluña y el Consejo de Gobierno de las Islas Baleares contra el Real Decreto 1.095/1989, de 8 de septiembre, por el que se declaran las especies objeto de caza y pesca y se establecen normas para su protección; el conflicto positivo de competencia 162/1990, promovido por el Gobierno Vasco contra el Real Decreto 1.118/1989, de 15 de septiembre, por el que se declaran las especies objeto de caza y pesca comercializables, el 210/1990, interpuesto por la Diputación Regional de Cantabria contra los dos Reales Decretos antes mencionados, y el $1.938 / 1990$, promovido por el Consejo Ejecutivo de la Generalidad de Cataluña contra el Real Decreto 439/1990, de 30 de marzo, por el que se regula el Catálogo Nacional de Especies Amenazadas. Voto particular. BOE181, 31/07/1995

Sentencia 15/03/1999, de la Sala Tercera del Tribunal Supremo, por la que se anula el artículo 13.2 del Real Decreto 1997/1995, de 7 de diciembre, que establece medidas para contribuir a garantizar la biodiversidad mediante la conservación de hábitats naturales y de la fauna y flora silvestres. BOE 141, 14/06/1999.

Sentencia 194/2004, de 4/11/2004. Recurso de inconstitucionalidad 460/1998, 469/1998 y 483/1998 (acumulados). Formulados por el Consejo de Gobierno de la Junta de Andalucía, las Cortes de Aragón y la Diputación General de Aragón respecto de la Ley 41/1997, de 5 de noviembre, por la que se modifica la Ley 4/1989, de 27 de marzo, de conservación de los espacios naturales y de la flora y fauna silvestres. Competencias sobre medio ambiente y espacios naturales protegidos: Organización y gestión de los parques nacionales; planificación y financiación (STC 102/1995). Nulidad e interpretación de preceptos estatales. Voto particular. BOE 290, 2/12/2004. 